Danmarks geologiske Undersøgelse.

II. Række. Nr. 35.

\title{
Stenalderhavets Udbredelse
}

i

det nordlige Jylland.

Ved

Axel Jessen.

Med 1 Kort og

an English summary of the contents.

Kjøbenhavn.

I Kommission hos C. A. Reitzel.

Trykt hos Nielsen \& Lydiche (Axel Simmelkiær)

1920.

Pris : $3 \mathbf{K r}$. 
Danmarks geologiske Undersøgelse.

II. Række. Nr. 35.

\title{
Stenalderhavets Udbredelse \\ i \\ det nordlige Jylland.
}

\author{
Ved \\ Axel Jessen. \\ Med 1 Kort og \\ an English summary of the contents.
}

Kjøbenhavn.

I Kommission hos C. A. Reitzel.

Trykt hos Nielsen \& Lydiche (Axel Simmelkiær)

1920. 
INDHOLD.

Indledning . . . . . . . Side

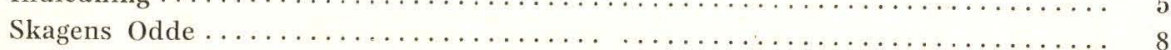

Fra Frederikshavn over Hals til Nørresundby. Læsø.............. 16

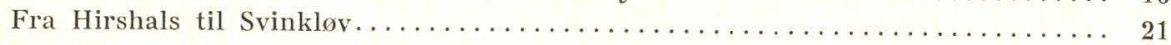

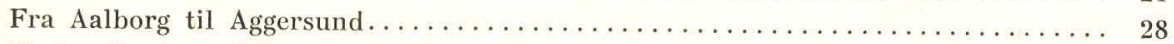

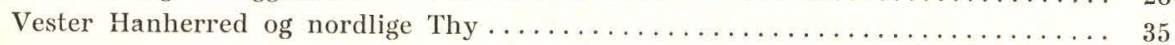

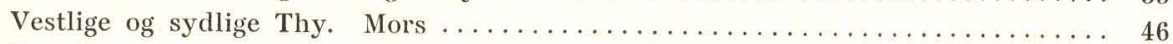

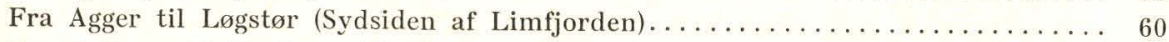

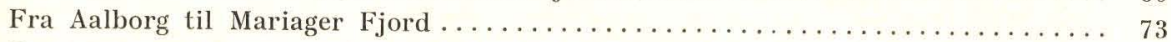

Fra Mariager Fjord over Djursland til Aarhus. Anholt.............. 80

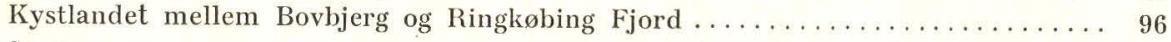

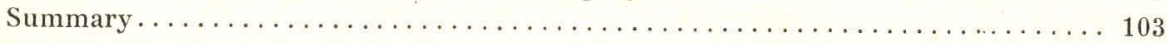




\section{Indledning.}

Gor snart Hundrede Aar siden paaviste den danske Geolog G. Forchhammer, at det nordøstlige Danmark i en Del af den postglaciale Tid havde ligget lavere end i Nutiden. Endvidere fandt han ved Maaling af hævede Havstokke, at den derpaa følgende Hævning af Landet havde været stærkest mod Nordøst, og at den aftog mod Sydvest til en Linje trukket fra Nissum Fjord mod SØ til noget Syd for Nyborg. Sydvest for denne Linje laa de højeste Havstokke ikke højere end den øverste Tanglinje, og nogen Landhævning havde altsaa ikke fundet Sted her.

Senere Aars Undersøgelser har fuldt ud bekræftet disse Iagttagelser. Ved geologisk-arkæologiske Undersøgelser er det endvidere lykkedes nærmere at bestemme det Tidspunkt, da Landet i det nordøstlige Danmark laa lavest. Dette Tidspunkt, Landsænkningens Maksimum, falder i store Træk sammen med det Afsnit af den danske Eldre Stenalder (Campinien), der er karakteriseret ved Affaldsdyngerne (Kjøkkenmøddingerne) og Skivespalter- eller Ertbølle-Kulturen. Andre, først og fremmest svenske Forskere, har yderiigere udvidet vort Kendskab til Niveauforandringerne efter Istiden og disses Samtidighed med kendte klimatiske og arkæologiske Perioder.

De Niveauforandringer, der har spillet en Rolle for vort Land, er i korte Træk følgende: Da Indlandsisen smeltede bort fra det nordøstlige Danmark, sænkedes Landet, stærkest mod Nordøst. Denne senglaciale Landsænkning har i Særdeleshed sat sine Spor i Vendsyssel, hvor Egnen omkring Frederikshavn laa omtrent $60 \mathrm{~m}$ lavere end i Nutiden. Mod Sydvest var Sænkningen ringere; i MidtVendsyssel laa Landet ca. $40 \mathrm{~m}$ og ved Aalborg noget over $20 \mathrm{~m}$ lavere end nu; Sydvest for en Linje fra Løgstør mod SØ over Djursland til Nordøst-Sjælland maa Landet under den senglaciale Landsænknings Maksimum have ligget højere end i Nutiden, idet senglaciale Ferskvands-Aflejringer med arktiske Planter her kan findes under Havets Niveau.

Under den paafølgende Landhævning, ved hvilken den gamle 
Ishavsbund i Vendsyssel hævedes op over Havet, steg Temperaluren. Hævningen, der dog blev afbrudt af en ringere Landsænkning, under hvilken en Stranddannelse, Zirphæalaget, aflejredes i den nordlige Del af Vendsyssel, kulminerede i Fastlandstiden (Ancylustiden), da hele Danmark laa betydelig højere end i Nutiden, og da Kystlinjen maatte søges langt udenfor den nuværende. Blandt andet var Jylland over Fyn og Sjælland forbundet med Skaane, og den sydligste Del af Nordsøen var Land.

Derefter fulgte den Landsænkning, Litorina-Sænkningen, hvis Virkninger i Nordjylland skal nærmere omtales i det følgende. Denne Landsænkning har ramt hele Danmark, men da der endnu ikke haves nogen nøjagtig Bestemmelse af, hvor højt Landet har ligget i Fastlandstiden, hverken mod Nordøst eller mod Sydvest, er det ikke muligt at angive det absolute Tal for hele Niveauforandringens Størrelse; derimod kan man ret nøje angive, hvor meget det nordøstlige Danmark ved denne Landsænkning bragtes ned under Nutidens Niveau. I det sydvestlige Danmark, der som nævnt ogsaa sænkedes, dækkedes meget store Landstrækninger af Havet; dog var disse sydvestlige Egne endnu ikke - paa det Tidspunkt, hvor det nordøstlige Danmark var sænket dybest (Litorina-Sænkningens Maksimum) - naaet ned til samme Niveau som i Nutiden, men laa endnu den Gang adskilligt højere. Under Litorinatidens sidste Afsnit hævedes det nordøstlige Danmark op til sin nuværende Højde, medens Sænkningen $i$ det sydvestlige Danmark endnu fortsattes i nogen Tid. Denne Sænkning synes i det sydvestlige Jylland atter at være bleven afløst af en efter Broncealderen indtraadt, mindre Hævning.

Da Landhævningen efter Litorina-Sænkningens Maksimum har været størst mod Nordøst, maa man ogsaa vente at finde de største Forandringer i Landets Kystomrids i det nordligste Jylland. Dette er ogsaa til en vis Grad Tilfældet, omend ogsaa andre Faktorer har gjort sig gældende, i forskellig Grad paa de forskellige Steder. Har Havdybden udenfor den tidligere Kystlinje været meget ringe, vil selv en ubetydelig Landhævning medføre Tørlæggelsen af store Arealer. Lige saa stor Betydning maa tillægges Kyststrømmen og Bølgeslaget, der udgraver, flytter og atter aflejrer Materiale. Langs en Kyst, der ligger ubeskyttet ud mod en herskende Vindretning, saaledes som Vesterhavs- og Skagerrakkysten, vil Kyststrøm og Bølgeslag altid spille Hovedrollen. Fremragende Pynter vil angribes stærkt og lidt efter lidt rykkes tilbage; selv haard Kalksten maa i Tidens Løb vige for Havets Angreb. Kyststrømmen vil føre Materialet ind i Bugterne, hvor Bølgeslaget kaster det op paa Kysten, eller der lægges fra Pynt til Pynt en Revle, der afspærrer en Lagune indenfor. Havet søger at gøre Kystlinjen saa jævn som mulig, enten som en 
ret Linje eller som en Række meget flade Buer, der forbinder de faste Punkter. I det følgende skal blandt andet omtales, hvorledes en Del af Vesterhavets og Skagerraks Kyst ved Litorina-Sænkningens Maksimum var en fliget, dybt indskaaret Kyst, opstaaet under usædvanlige Forhold, men af en Form, der var aldeles uholdbar overfor Vesterhavets Virkemaade. Kystlinjen maatte jæevnes ud, og den blev det; noget Land blev skaaret bort, men langt større Arealer udfyldtes og omdannedes til Land. Længere Syd paa, langs Slesvigs Vestkyst, kommer en anden Faktor til, nemlig Ebbe og Flod og de dermed følgende Kyststrømninger, der ikke alene holder de gamle Render mellem Øerne aabne, men endog paa sine Steder har kunnet udgrave dem til langt større Dybder, end de oprindelig har haft.

Langs Kattegats og Limfjordens Kyster, hvor der løber eller har løbet stærk Strøm langs Landet, spiller Tilsandingen ligeledes en meget stor Rolle ved Dannelsen af nyt Land og har i Særdeleshed tidligere, da den kombineredes med en Landhævning, været af væsentlig Betydning. Inde i Fjorde, hvor Strømmen er underordnet og Bølgeslaget ringe, vil Aflejringen af Ler og Dynd, ført ud med Aaløbene eller skyllet ned fra det omgivende Land, være den Faktor, der i Forbindelse med Tilgroning og eventuelt Landhævning spiller den største Rolle ved Nydannelsen af Land. 


\section{Skagens Odde.}

Vendsyssel er den Del af Danmark, hvor Landets Hævning siden Litorina-Tiden har været størst, og betydelige Strækninger af den gamle Havbund er derved blevet omdannede til tørt Land. Ved sin Beliggenhed som Skel mellem to Have har Landets Kyster desuden været og er endnu i høj Grad udsatte for Strømmens og Bølgeslagets Virkninger. Terrainformerne og de geologiske Forhold vidner om, at Havet har gravet store Dele af det gamle Land bort, i Særdeleshed paa Vestkysten; men samtidig falder det i Øjnene, hvor meget større den Tilvækst af Landet har været, som skyldes Landhævningen i Forbindelse med de af Strømmen transporterede og atter aflejrede Grusmasser, først og fremmest paa Nordkysten, hvor Skagens Odde er vokset længere og længere ud $\bmod$ Nordøst $^{1}$ ).

Da Stenalderhavet havde sin største Udbredelse, løb Kystlinjen fra Frederikshavn mod VNV og NV forbi Kvissel, langs Foden af de høje Bakker ved Eskjær, ud mod Tversted og herfra forbi Uggerby til Pynten ved Hirshals. Fra denne gamle Kystlinje er det store Lavland, Skagens Odde, vokset ud ved en Samvirken mellem Landets Hævning og Kyststrømmens Materialtransport. Grundlaget for Odden eller enkelte Støttepunkter for dens Vækst er dog af æeldre Oprindelse, idet den gamle Ishavsbund paa flere Steder ligger saa tæt under Overfladen, at den i Litorinatiden maa have dannet enten et af nogle faa Meter Vand dækket, submarint Plateau eller flade Lerbanker, som Strømmen er bøjet uden om. Et stort Plateau af glacialt Ler, dækket af et tæt Lag af fritskyllede, store Sten, findes Nord for Frederikshavn og strækker sig helt ud til Strandby. Et andet Lerplateau træffes Øst for Tversted ud mod Nørre Elkjær og Østenkjær. Størst Betydning har dog den Lerbanke haft, der kendes fra Partiet mellem Raabjerg Kirke og Kandestederne, og paa hvilken nu den kendte, ubevoksede Klit, Raabjerg Mile, ligger.

$\left.{ }^{1}\right)$ A. Jessen. 1899. Kortbladene Skagen, Hirshals, Frederikshavn, Hjøring og Løkken. D. G. U. I. Række, Nr. 3. Kjøbenhavn.

" 1918. Vendsyssels Geologi. D. G. U. V. Række, Nr. 2. København. 
Leret (vistnok senglacialt Yoldialer) er bl. a. set ved Lavvande i Havstokken, og gamle Vrag, der ligger i Stranden her ud for, har i adskillige Tilfælde arbejdet sig ned igennem Strandsandet og staar nu paa fast Lerbund.

Kyststrømmen, der ved. Sænkningens Maksimum, løb dels fra Frederikshavn mod Nordvest langs Landet ud mod Tversted, dels langs Skagerrak-Kysten fra Hirshals mod Øst til Tversted, førtes herfra ud mod Lerbanken ved Raabjerg; her ud imod transporteredes Sand og Grus, hvorved der efterhaanden opbyggedes Revler og Harstokke, saaledes at Raabjerg-Banken blev forbundet med det faste Land. Fra Egnen ved Frederíkshavn og udad mod Nordvest aflejredes en bred Sandrevle parallelt med og i nogen Afstand fra den gamle Kyst. Udfor Kvissel og Tolne har Revlen Karakter af en meget bred, flad Strandvold, hvis Ryg nu ligger 13-14 m o. H. og længere mod Nordvest, ved Bollehede og Blæsbjerg, noget over $14 \mathrm{~m}$ o. H. Endnu videre mod Nordvest bliver Revlen bredere og deler sig i et Systen af Rygge, Rimmer, med mellemliggende, nu tørvefyldte Lavninger, Dopper, der spreder sig vifteformet fra Nordvest til Nord, saaledes at de ældste Rygge nærmest det gamle Land har Retning ud mod Østenkjær, medens de noget yngre og østlige bøjer mere og mere mod Nord, til sidst endog i en Bue mod Nordøst og Øst hen imod Lerbanken ved Raabjerg.

Vanskeligt er det at følge Retningen af disse Rimmer, der udelukkende bestaar af Sand, idet Sandflugten i senere Tider er gaaet hen over Egnen og har udvisket Rimmerne. Man har da som Regel kun de med Tørv fyldte Dopper at holde sig til, idet de som oftest kan eftervises og følges selv under et ret tykt Dakke af Flyvesand. I enkelte Tilfælde bestaar Rimmerne dog af grovere Materiale og nærmer sig da den sædvanlige Strandvold-Type. Dette er f. Eks. Tilfældet med en af nødde- og ægstore Sten bestaaende Grusrevle, der mellem Skiveren og Slynge, Nordvest for Gaardbosø, strækker sig fra VSV til ØNØ langs Sydsiden af Raabjerg Banken, og som naar til en Højde af $14.7 \mathrm{~m}$ o. H. Paa Grund af det omgivende og til Dels dækkende Flyvesand er dog ogsaa denne Strandvold lidet fremtrædende i Terrainet.

Aflejringen af den store Sandrevle fra Frederikshavn til Tversted maa dog være begyndt allerede i Slutningen af den senglaciale eller Begyndelsen af den postglaciale Tid, og maaske har Revlen dannet Landets Nordgrænse i Fastlandstiden. I Lavningen mellem Revlen og Højlandet er der nemlig paa adskillige Steder iagttaget Tørvelag, der dækkes af de i Litorina-Tiden aflejrede Lag af marint, skalførende Ler og Dynd. Tørven med dens talrige Stammer af Fyr hidrører aabenbart fra Fastlandstiden og viser altsaa, at paa den Tid har 
Landet naaet i alt Fald saa langt ud mod Nord. Under LitorinaSænkningens Maksimum har Sandrevlen været dækket af Havet, saaledes at Kystlinjen løb langs Foden af Højlandet; først under den derpaa følgende Landhævning fik Revlen sin nuværende Form, og efter at den var bleven hæevet op over Havet, opstod der mellem den og Højlandet en Lagune, i hvilken der aflejredes Saltvands-Ler og -Dynd ovenpaa Fastlandstidens Tørvemoser.

Længst mod Sydøst i Egnen ved Kvissel har marint Ler med en temmelig rig Molluskfauna udfyldt hele Lagunen mellem Strandvolden og Højlandet; Profiler ses flere Steder, bl. a. ved Sydsighave Teglværk, der netop er baseret paa dette postglaciale, marine Ler. Her naar det skalførende, marine Ler indtil $8.5 \mathrm{~m} \mathrm{o}$. H.; dets Mægtighed veksler fra $2-3^{1 / 2} \mathrm{~m}$, og Underlaget er et indtil $1.3 \mathrm{~m}$ tykt Tørvelag, der indeholder Rester af Fyr, Birk og Hassel, og som hviler paa Sand. Noget længere mod Nordvest naar det marine Ler til henved $12 \mathrm{~m}$ o. H., medens Ryggen af Strandrolden udenfor ligger $13.5 \mathrm{~m}$ o. H. Endnu længere mod Nordvest, udfor Tolne, Mosbjerg og Bindslev Sogne, dækkes de gamle Fjordaflejringer af store Tørvemoser, hvor Tørvedybden stiger til $4-8 \mathrm{~m}$. Ved Boringer er det skalførende, marine Ler fulgt over hele denne Strækning mod Nordvest ud mod Tversted; under Moserne findes det til en Højde af $11.3 \mathrm{~m}$ o. H., og mellem Stensbæk og Nørre Elkjær, hror det som et forholdsvis tyndt Lag af skalfrit, marsklignende, fint Ler kommer frem i Overfladen over et stort Areal, naar det endog til hen imod $13 \mathrm{~m} \mathrm{o.} \mathrm{H.} \mathrm{Ved} \mathrm{Nørre} \mathrm{Elkjær} \mathrm{forekommer} \mathrm{marint} \mathrm{Ler} \mathrm{med} \mathrm{en}$ Fauna op til ca. $12 \mathrm{~m}$ o. H., medens skalførende Strandsand findes ude paa den flade Slette indtil $12.8 \mathrm{~m}$ o. $\mathrm{H}$.

Den gamle Kyst indenfor Lagunen er meget iøjnefaldende, og paa lange Strækninger staar den som en høj og stejl Skrænt. Selve Kystlinjens Højde over Havet lader sig dog kun maale nøjagtigt paa enkelte Steder, omkring Kvissel og NØ for Bindslev, hvor velbevarede Erosionsterrasser findes $14-15 \mathrm{~m}$ o. H. Men som oftest er Strandlinjen dækket dels af udskyllet Sand fra Bakkerne, dels af de store Moser, der i Tidens Løb er voksede op ved Skræntens Fod.

De højest liggende Kystlinjer og Aflejringer fra Stenalderhavets Tid er altsaa: Erosionsterrasserne i Foden af det gamle Højland 14-15 m o. H., Strandvolden eller Revlen fra Frederikshavn ud mod Tversted over $14 \mathrm{~m}$, marint Ler mellem denne Revle og Højlandet mellem 12 og $13 \mathrm{~m}$ og skalførende Strandsand ude paa Sletten til hen imod $13 \mathrm{~m} \mathrm{o.} \mathrm{H.;} \mathrm{endelig} \mathrm{den} \mathrm{stenede} \mathrm{Strandvold} \mathrm{ud}$ mod Raabjerg $14.7 \mathrm{~m}$ o. H. Man tør da gaa ud fra, at Landhævningen siden Litorina-Sænkningens Maksimum i denne Egn har været over $12 \mathrm{~m}$, snarere henved $13 \mathrm{~m}$. 
Den store Sandrevle, der fulgte Højlandet fra Frederikshavn til hen imod Tversted, bøjer, som allerede nævnt, her bort fra den gamle Kyst og drejer mod Nord og Nordøst ud mod Banken ved Raabjerg. Dette skyldes rimeligvis den stærke, østgaaende Strøm, der den Gang ligesom i Nutiden maa have fulgt Landets Nordkyst fra Hirshals forbi Uggerby og Tversted. Denne Kyststrøm, der førte meget Sand med sig, har haft sin meget væsentlige Andel i Opbygningen af Skagens Odde. Paa et tidligt Tidspunkt er der sandsynligvis aflejret en Revle eller Strandvold udenfor den daværende Kystlinje mellem Hirshals og Raabjerg Banken; det meste af, hvad der den Gang byggedes op, er dog atter skyllet bort, og vi finder nu kun det nordligste Parti af dette Strandvoldsystem bevaret i Egnen mellem Skiveren og Raabjerg. Men at det maa have eksisteret, ses ikke alene ved en Betragtning af Højdekortet over Egnen mellem Tversted og Kandestederne, men bevises direkte ved Forekomsten af Fjord-og Laguneaflejringer paa fuldkommen ubeskyttede Steder, saaledes nær Mundingen af Uggerby Aa, ved Tversted Aa Nord for Tversted Kirke, ved Flodbæk og ved Nørre Elkjær. Disse skalførende Litorinalag viser saa udpræget Fjordkarakter, og i enkelte Tilfælde (ved Tversted Teglværk) tyder Faunaen paa saa brakt Vand, at de umuligt har kunnet dannes ved en aaben Skagerrak-Kyst, men maa have været beskyttede mod og delvis afspærrede fra Havet ved en nu bortskyllet Revle.

Ved Teglværket ved Tversted Aa nær dennes Munding findes den oftere omtalte Lagrække, der paa instruktiv Maade viser de fra Istidens Slutning indtil Nutiden foregaaede Niveauforandringer, nemlig nederst senglacialt Yoldialer (aflejret paa dybt Vand i Ishavstiden), derover Zirphæagrus (Stranddannelse, Landhævning), derover lagdelt Zirphæasand (aflejret paa dybere Vand, Landsænkning), derover et Tørvelag med Rester af Fyr (Landhærning, Landoverflade fra Fastlandstiden), derover marint Dynd og Ler med en Fjordfauna (Litorina-Sænkningen, Stenalderhavet) og øverst Flyvesand (Landhævning, den nuværende Landoverflade).

Efter at Raabjerg Banken var bleven hævet op over Havet og samtidig var bleven landfast med Højlandet mod Syd og Sydvest, blev den det faste Knudepunkt, uden om hvilket de ydre Partier af Skagens Odde byggedes op, samtidig med at Landet hævedes, idet Strandvold efter Strandvold lagde sig koncentrisk uden om Banken ligesom Aarringe $\mathrm{i}$ en Træstamme.

Medens Kyststrømmen under Litorina-Sænkningens Maksimum løb fra Frederikshavn mod Nordvest og aflejrede den ovenfor omtalte Sandrevle langs Landet udad mod Tversted, maa det modsatte have været Tilfældet paa det Tidspunkt, da Raabjerg Banken dannede 
Oddens yderste Del. Kyststrømmen og med den en meget betydelig Sandvandring bevægede sig da fra Nord mod Syd langs Oddens Østside, mulig som et Slags Idvande, betinget af Landets ejendommelige Form paa dette Tidspunkt. Derved afspærredes den dybe Bugt Syd for Raabjerg Kirke fra Kattegat og omdannedes til en Lagune, den nu udtørrede Gaardbo Sø, der senere lidt efter lidt udfyldtes med marint Ler og Dynd, ligesom Lagunen Syd paa langs Højlandet. Nærmest Sydøst for Raabjerg aflejredes groft Sand og Grus, sydligere aflejredes kun Sand, og samtidig udvikledes disse Stranddannelser til et stort, bredt og meget ejendommeligt System af smalle Sandrygge, Rimmer, adskilte ved noget bredere, nu oftest tørvefyldte Lavninger, Dopper. Dette ualmindelig smukt udviklede Rimmesystem, der breder sig vifteformet ud $\bmod \mathrm{SV}, \mathrm{S}$ og $\mathrm{S} \varnothing$, viser saa tydeligt som muligt, at Materialtransporten her er foregaaet fra Nord mod Syd. De ældste Rimmer, der udgaar fra Egnen ved Lyngshede, er mod Nord smalle, skarptformede og ligger meget tæet ved Siden af hinanden; Syd paa i Raabjerg Mose spredes de mere og mere, dog saaledes, at Rimmerne stadig er smalle og rygformede, hvorimod de mellemliggende, tørvefyldte Dopper bliver bredere og bredere. Først ca. $3 \mathrm{~km}$ fra Udgangspunktet løber Rimmerne parallelt og beholder herfra deres indbyrdes Afstand mod Sydøst til hen imod Frederikshavn, hvor de, uden at samles i et fælles Udgangspunkt som mod Nord, bliver fladere og taber sig mere og mere. I Raabjerg Mose, hvor Rimmerne er mest typiske, varierer deres Bredde fra 10 til 50 m, og Højden over Tørvedopperne fra 1 til $3 \mathrm{~m}$. Rimmesystemets Højde er størst mod Nord i den ældste Del og aftager herfra mod Syd og Sydøst.

Udenfor dette ældste, vifteformede Rimmesystem i Raabjerg Mose, og adskilt herfra ved et Bælte af uregelmæssigt formede Flyvesandsbanker og Lavninger, ligger et andet Rimmesystem parallelt med den nuværende Kattegatskyst. I dette Parti løber Rimmerne parallelt og har ikke noget fælles Udgangspunkt. Højderne er omtrent ens mod Nord og Syd, men aftager kendeligt fra Vest mod Øst ud mod den nuværende Kyst. Disse østlige Rimmer er opstaaede senere, under en længere Tidsperiode med jævn Landhævning, og rimeligvis under samme Strømforhold som i Nutiden i Aalbæk Bugt. Mellem disse Rimmer og Kattegatskysten findes et bredt Bælte af flade, lavtliggende Strandenge uden nogen som helst Rimmedannelse.

Om Oprindelsen til disse ejendommelige, brede Systemer af Rimmer har der været opstillet forskellige Teorier, der dog alle manglede det faste Grundlag, som en direkte Iagttagelse af en lignende Dannelse i Nutiden kunde byde. Langs den nuværende Kyst mellem Frederikshavn og Skagen foregaar der nemlig ikke mere nogen Rimme- 
dannelse; først efter at en saadan er fundet langt sydligere, paa Vendsyssels Østkyst nær Hals, hvor Kysten er flad, og Havet udenfor har meget ringe Vanddybde, er man naaet til et nogenlunde sikkert Resultat. Det kan da siges, at Grundlaget for disse, af stenfrit, ensartet Sand bestaaende, smalle, parallele Rygge er flade Revler af Strandsand, paa hvilke den hurtigt opvoksende Vegetation har fanget Flyvesandet, hvorved Revlerne er voksede stærkere i Højden end deres Omgivelser. Rimmernes Hovedmasse er derfor Flyvesand, men da Grundvolden er Strandsand, maa de alligevel betragtes som ægte Kystfænomener, der i forstærket Form angiver de tidligere Kystlinjers Beliggenhed.

Foruden det nu omtalte store og karakteristiske Rimmeparti SØ for Gaardbosø findes der flere andre Steder paa Skagens Odde Rimmer og Dopper, der dog ikke giver sig saa tydeligt tilkende i Terrainet, idet de ved Sandflugten er blevet udjævnede eller endog fuldstændig dækkede af Flyvesand. I disse Tilfælde er det egentlig kun ved Hjælp af de parallelt løbende, smalle, tørvefyldte Dopper, at saadanne Rimmesystemer har kunnet eftervises. NØ for Gaardbosø ligger der saaledes Tørvedopper, der har Retningen $\varnothing-\mathrm{V}$, og som angiver den tidligere Kystlinje paa Sydsiden af Raabjerg Banken. Ogsaa paa Øst- og Nordsiden af denne Banke kan der eftervises Tørvedopper, hvis Retning drejer fra $\mathrm{S}-\mathrm{N}$ til $\mathrm{S} \varnothing-\mathrm{NV}$, svarende til de tidligere Kystlinjer her; Dopperne med deres af Flyvesand dækkede og sammenpressede Tørvelag, Martørv, naar ud til Stranden mellem Kandestederne og Spirbakke Mile, hvor de afskæres af den nuværende Kystlinje og saaledes vidner om, at Landet tidligere maa have strakt sig betydelig længere ud mod Vest end i Nutiden.

Opbygningen af Skagens Odde foregik altsaa for en Del ved Dannelsen af Revler og Strandvolde, der samtidig med at Landet hævedes, lagde sig som Tilvækststriber uden om den ældre Kærne. Mellem saadanne Revler og Land er der paa flere Steder opstaaet Laguner, i hvilke der aflejredes Ler- og Dyndlag med en Fjordfauna, undertiden endogsaa en Brakvandsfauna. Disse Laguneaflejringer, som man ikke skulde vente at finde paa denne, nu fuldstændig aabne Kyst, ses blandt andet mellem Skiveren og Kandestederne, hvor Strømmen i Nutiden skærer stærkt ind paa Kysten og blotter høje Profiler i de postglaciale Lag. I en Højde af 9-10 m o. H. findes her indlejret i groft Strandsand et $1 / 2-1 \mathrm{~m}$ tykt Lerlag, der indeholder en fattig Cardiumfauna, Rester af Tang m. m., medens der i de omgivende Sand- og Gruslag findes rullede Skalfragmenter som Repræsentanter for Faunaen ved den aabne Skagerrak-Kyst.

Efterhaanden som Odden voksede længere og længere ud mod Nordøst, skar den fra Hirshals kommende, østgaaende Kyststrøm 
stadig stærkere ind mod Kysten. Der foregik da omtrent langs hele Oddens Vestside en betydelig Nedbrydning af det kort forinden opbyggede Land. De Stranddannelser, indenfor hvilke de S. 11 omtalte Lagune- og Fjordaflejringerne ved Uggerby Aa og Tversted Aa var dannede, skylledes bort, og fra Tversted til Raabjerg Banken naaede Bortskylningen endog helt ind til den æeldste og højeste Del af Odden. Endnu i vore Dage lǿber Strømmen haardt paa Land paa hele Strækningen fra Tversted ud til Højen (Gammèl Skagen), og stadig tages der lidt bort af de løse Sand-og Grusskrænter, hvorved den over Strandsandet liggende Martørv undergraves og styrter ned som store Blokke. Af større Betydning er denne Bortskylning dog ikke, hvad der ses ved en Sammenligning mellem Videnskabernes Selskabs Kort fra 1785 - 87 og Generalstabens Kort fra 1886-88. Størst er Forandringen længst mod Nord; Bortskylningen har været temmelig stærk baade Syd og Nord for Gammel Skagen, men afløses ved Højen Fyr, NØ for Gammel Skagen, af en Tilvækst af Landet. Her ude paa den yderste Del af Odden viser det store System af koncentriske eller parallele, stenede og grusede Strandvolde, hvorledes Landet er vokset udad mod Nord ved, at det ene Bælte af Strandgrus er lagt udenfor det andet. Alene i de 100 Aar mellem de nævnte Opmaalinger har Tilvæksten af Land paa Skagens Nordstrand været $3-400 \mathrm{~m}$, Nord for Skagens Fyr endog $500 \mathrm{~m}$. Da der samtidig paa Sydøstkysten, i Særdeleshed mellem Skagen By og Fyret, skæres Land bort (en Bortskæring der, efter at Havnen ved Skagen er blevet bygget, er bleven usædvanlig stærk), foregaar der en Forskydning af Oddens yderste Del, Grenen, fra Syd til Nord, dog saaledes at dens Spids stadig peger i omtrent samme Retning, mod Øst. Ifølge Kortene laa i 1787 Spidsen af Grenen 900 m sydligere end i 1887.

Selve Grenen er iøvrigt ogsaa i Nutiden meget varierende i sin Form; snart er den but og afrundet, snart danner den en lang, smal Revle, i hvis Fortsættelse mindre Sandbanker kan rage op over Havet. Videre ud under Havet fortsættes Grenen mod ØNØ i det 3-4 km lange Skagens Rev; Revet bestaar af haardt, hvidt Sand uden andre Sten end dem, der hidrører fra Ballast fra strandede Skibe. Medens Revets Sydside danner en jævn Skraaning, er dets Nordside meget stejl; Havbunden stiger her brat fra $\div 25 \mathrm{~m}$ til $\div 8 \mathrm{~m}$.

Ved de Forandringer, der efter Stenalderhavets Tid er foregaaet med Skagens Odde, har dens Overflade skiftet Karakter, og den marine Oprindelse er blevet delvis udvisket. Store Strækninger af det nydannede Land, der bestod af Strandvolde, Rimmer, Dopper og større Lavninger, dækkedes efterhaanden af Krat og Skove, bestaaende af Bævreasp, Pil, Birk, Eg og sjældnere af Fyr. I de fug- 
tige Lavninger, dels i den tidligere Lagune langs Højlandet, dels i Dopperne, begyndte en Tørvedannelse, nederst af Kærtørv med Rester af de nævnte Skovtræer; senere trængtes Skovvegetationen bort fra de lavere Strækninger som Følge af det efter Broncealderen indtrædende koldere og fugtigere Klima, og Tørven gik lidt efter lidt over til at blive en ren Sphagnumtørv.

Mod Nord og Vest blev Tørvedannelsen standset af den store Sandflugt, der i høj Grad ændrede Overfladens Udseende, og som Nord for Gaardbosø gik tværs over hele Landet fra Vestkyst til Østkyst; hvor Vandreklitter gik hen over Tørvemoserne, sammenspressedes Tørven og omdannedes til Martøv. Samtidig med, at der stadig er tilført nyt Flyvesand nede fra Stranden, er der paa enkelte Strækninger, stærkest langs Oddens Vestkyst, foregaaet en meget betydelig Vinderosion. Ikke alene Flyvesandet kan herved være ført bort, men ogsaa store Partier af det underliggende Strandsand; Erosionen er forst stanset, naar de i Sandet og Gruset liggende Strandsten har dannet et saa tæt Lag, at det underliggende Sand derved beskyttedes mod Bortblæsning. Herved er fremkommet de saakaldte Stensletter: jævne, vegetationsløse Flader, dækkede af et mere eller mindre tæt Lag af stæerkt sandslidte Strandsten. Hvor Strandsandet dækkes af Martørv, beskyttes Sandet mod Bortblæsning, hvorimod de mellemliggende Sandrimmer og Strandvolde udhules af Vinden, og der indtræeffer da det ejendommelige Forhold, at Tørven, der oprindelig dannedes paa de laveste Steder, i Dopperne, nu i Reglen ses liggende i Skrænterne flere Meter højere ved Stensletterne, de tidligere Rimmer.

De ude paa Skagens Odde fundne Oldsager giver os enkelte Vink om Alderen af de forskellige Aflejringer. Under Martørven, direkte paa Strandsandet, og i Martørvens nederste Del er der fundet mange Flintsager ${ }^{1}$ ), blandt andet nær Kandestederne, hvor der har været et Tilhuggervarksted, samt paa spredte Steder i den sydlige Del af Skagens Landsogn. Landhævningen og Tilvæksten af Land er altsaa gaaet saa hurtig for sig, at Skagens Odde allerede i den yngre Stenalder har haft en betydelig Udstrækning. Ikke alene var Banken ved Raabjerg bleven landfast med det øvrige Vendsyssel, men Landet var vokset videre ud mod Nordøst forbi Kandestederne og Hulsig. Broncesager, dels enkelte Stykker dels samlede Fund, er optagne paa flere Steder i Martørven og forekommer adskilligt længere udad mod Gammel Skagen end Flintsagerne. Hvor langt Landhævningen og Oddens Tilvækst var naaet ved Broncealderens Slutning, har dog endnu ikke kunnet fastslaas.

1) A. P. GaArdboe. 1893. Fortidsminder fra Vendsyssel. Aarhus. 
Paa Strækningen fra Tversted mod Vest til Hirshals er den Grænse, hvortil Havet er naaet under Litorina-Sænkningens Maksimum, vanskelig at eftervise. Strandvolde eller gamle Kystbrinker findes saa godt som slet ikke. Paa nogle Strækninger har Flyvesandet virket forstyrrende, men Hovedgrunden er aabenbart, at der som omtalt S. 11 her udfor maa have ligget en af Bølgeslaget og den stærke østgaaende Strøm opbygget Barre eller Revle, der i lang Tid har beskyttet Kysten mod Havets Virksomhed. "Denne Kyststrækning er derfor først $\mathrm{i}$ en senere Tid, efter at Strømmen var begyndt at skære bort baade her og paa Vestsiden af Skagens Odde, bleven en ægte Skagerrak-Kyst. Hvad der findes af højtliggende, marine Lag er derfor kun de indenfor denne Barre afsatte Laguneog Fjordaflejringer.

Lagfølgen ved Tversted Teglværk er omtalt S. 11. I det marine Ler, der benyttes af Teglværket, findes en meget fattig Fjordfauna, karakteriseret ved tyndskallede Eksemplarer af Cardium edule; i leret Sand, liggende $\mathrm{i}$ et lavere Niveau, er Faunaen noget rigere og indeholder blandt andet Osters. Ved Uggerby ses marint Ler og Dynd i Brinkerne langs Uggerby Aa indtil lidt Syd for Kirken og desuden i Kløfterne omkring de Vest fra kommende, smaa Vandløb Bovbæk og Ransbæk; de marine Lag findes paa disse Steder indtil 9-12 m o. H.; ved Ransbæk er de endog ved Boringer paavist op til ca. $13 \mathrm{~m}$ o. H. Først paa langt lavere Niveau, $6-7 \mathrm{~m}$ o. H., traffes mellem Uggerby og Hirshals rene Stranddannelser, Sand og Grus, med en rig Skagerrakfauna. Længst mod Vest ved Hirshals, der gennem hele Litorinatiden har været det faste Støttepunkt for de forskellige Kystlinjer, findes udprægede Stranddannelser til meget stor Højde. Stenede Strandvolde kan her følges fra den nuværende Kystlinje op indtil $14.9 \mathrm{~m} \mathrm{o.} \mathrm{H.}$

\section{Fra Frederikshavn over Hals til Nørresundby. Læsø.}

Paa Vendsyssels Østkyst ${ }^{1}$ ) er Kystlinjen mellem Frederikshavn og Sæby ikke undergaaet store Forandringer siden Stenalderhavets Tid. Den høje, stejle Bakkeskrænt, der mellem Bangsbo Aa og Sæby Aa hæver sig tæt indenfor den nuværende Kystlinje, viser, at der her er foregaaet en stærk Erosion, næppe alene i postglacial

1) A. Jessen. 1899. Anf. St.

1905. Kortbladene Aalborg og Nibe (nordlige Del). D. G. U. I. Række. Nr. 10. Kjøbenhavn. 
Tid, men utvivlsomt ogsaa tidligere i den senglaciale Ishavstid. Faa Steder i Landet finder man saa høje og imponerende og saa velbevarede, gamle Kystskrænter som her. Længst mod Nord, hvor Bakkerne har været dækkede af et tæt Lag store Sten, samledes disse, efterhaanden som Landet skylledes bort, som en beskyttende Forstrand langs Bakkefoden; endnu for faa Aar siden fandtes disse mægtige Ophobninger af store, afrundede Sten, undertiden sammen med Strandskaller, langs Foden af Bakkerne Syd for Bangsbo Aa, men de er nu for største Delen gravede op og anvendte ved Vej-, Jernbane- og Havneanlæg.

En Del af de fra Bakkerne nedskyllede Sten førtes af Kyststrømmen mod Nord og aflejredes ved Nordenden af Højlandet, hvor den daværende Kyst drejede lidt mod Nordvest, og hvor en smal Fjord strakte sig langt ind gennem Bangsbo Aa Dalen. Stenene aflejredes her som en Strandvold, hvis Rod støttede sig til Bakkefoden, og hvis Spids voksede videre som en Odde i Strømmens Retning, omtrent fra Syd til Nord. Strandvolden, der bestaar af næsten hovedstore, smukt rullede Sten, adskilte ved Lag af Sand og fint Grus, er nu for en Del bortgravet; den havde mod Syd tæt ved Bakkerne en Højde af $15.0 \mathrm{~m}$ o. H. og hørte saaledes til de højeste, marine Aflejringer i Danmark fra Stenalderhavets Tid.

Indenfor denne store Strandvold kan skalførende Fjordaflejringer, Ler og Dynd, ved Boringer følges op gennem Bangsbo Dalen indtil Sydøst for Flade Kirke og til en Højde af $12.5 \mathrm{~m}$ o. H. Nær Dalens Munding findes $\mathrm{i}$ de marine Lag en righoldig Ostrea-Fauna, længere inde en fattig Cardium-Fauna.

Ved Sæby Aa findes tilsvarende Forhold. Sæby ligger ude paa det nydannede Land ved Aaens Munding; tæt Vest for Byen staar den gamle Kystskrænt meget tydelig, omend ikke af saa betydelig Højde som længere Nord paa. Hvor Aaen kommer frem fra Højlandet er der i Fortsættelse af den gamle Kystlinje kastet en Strandvold op tværs over Dalen. Ryggen af denne stenede Vold naar en Højde af $13.5 \mathrm{~m}$ o. H., og indenfor har en Fjord strakt sig langt ind gennem den bugtede og ret snævre Dal. Marine Molluskskaller kan følges op langs Aaen til Sæby Gaard, og Brakvandsdynd, der naar indtil $10 \mathrm{~m}$ o. H., er paavist indtil ØSØ for Volstrup Kirke, hvor Banelinjen skærer Aaen.

Syd for Sæby har Tilvæksten af Land været større end mellem Sæby og Frederikshavn; Flyvesandet, der Syd for Sæby spiller en betydelig Rolle, har dog paa lange Strækninger skjult den gamle Kystskrænt. Et Par Steder findes Systemer af Rimmer og Dopper, men egentlige Strandvolde ses først 3-4 km NØ for Voers Aa, ved Møllerimmer, hvor de naar til $11 \mathrm{~m} \mathrm{o.} \mathrm{H.}$ 
Det store Sletteland omkring den nedre Del af Voers Aa bestaar af alluvialt, marint Ler og Sand, og Strandskaller ses almindeligt i Aabrinker og Grøfter. Over dette Areal har Stenalderhavet oprindelig bredt sig som en stor Bugt, der lidt efter lidt er bleven udfyldt og tørlagt. Fordelingen af Strandsand og marint Ler tyder paa, at Slettens nordøstlige Del tørlagdes først, og at Voers Aa da mundede ud i en smal Fjord, der fra Asaa strakte sig Nord paa indtil SV for Albæk. Senere udfyldtes denne Fjord med marint Ler, Mundingen lukkedes med Strandvolde, og Voers Aa gravede sig sit nuværende Leje gennem Strandsandet langs Sydranden af Albæk-Højlandet. Det marine Ler i den nævnte Fjord findes nu til en Højde af indtil $8 \mathrm{~m}$ o. H.; dets Mægtighed er indtil $6-8 \mathrm{~m}$, og ofte hviler det paa Tørvelag fra Fastlandstiden.

Sydvest for Albæk har Bugten været indsnevret, og kun et smalt Sund førte videre ind til et stærkt forgrenet Fjordsystem, der har udfyldt de nuværende Aadale omkring Voers Aa og dens Tilløb. Inde i disse lange, smalle Dale er de marine Lag, Ler og Dynd, oftest dækkede af Tørv, men paavises let ved Boringer. Paa denne Maade er Saltvands-Alluviet fulgt mod Nord langs Banelinjen til Dybvad, op ad Voers Aa til Knudseje, $2^{1 / 2} \mathrm{~km}$ paa den anden Side af Sæby-Aalborg Landevej, op ad Aadalene forbi Voer Kirke indtil 2-3 $\mathrm{km}$ Vest for Voer Gaard, mod Sydvest hen imod Øster Dorf og Løgtvedled tæt ved Dronninglund Storskov, og mod Syd til hen imod Ravnholt, Vest for Agersted Bakker.

Det skalførende, marine Ler naar i disse Fjorde til en Højde af $9-10 \mathrm{~m}$, i de nordlige Fjorde ved Dybvad og Knudseje til $10.5 \mathrm{~m}$ o. H. Det har en Mrgtighed af 5-8 $\mathrm{m}$ og hviler enten paa Sand eller paa Tørvemoser fra Fastlandstiden. Saaledes findes tæ SØ for Dybvad $5.7 \mathrm{~m}$ dyndet Saltvandsler, derunder $0.2 \mathrm{~m}$ Tørv og nederst Sand; i Nærheden af Voer Kirke findes 5.3-7.5 m marint Dynd, derunder et ganske tyndt Tørvelag og nederst Sand; Vest for Agersted findes $1 \mathrm{~m}$ Tørv, derunder $3.1 \mathrm{~m}$ marint Dynd, derunder $0.6 \mathrm{~m}$ Tørv og nederst Sand. Fastlandstidens Tørvelag er her fundne fra $5 \mathrm{~m}$ over Havet helt ned til Havets Niveau, og denne Egn maa derfor forud for Litorina-Sækningen have ligget i samme Højde som i Nutiden, mulig noget højere.

Fra Voers Aa og Syd paa til Limfjorden er den øverste Grænse for Stenalderhavet ikke synderlig iøjnefaldende; oftest viser den sig som smaa Erosionsterrasser og lave Kystbrinker, hvorimod stenede Strandvolde er sjældne. Ligesom i Nutiden maa Stranden udenfor ogsaa den Gang have været meget flad, Bølgeslaget svagt og Sten og Grus tilstede i meget ringe Mængde. Paa den hævede Havbund træffes nærmest Kysten rent Strandsand, hyppigt i Form af Nord-Syd 
gaaende Rimmer; i Lavningerne mellem Rimmerne og i de tidligere Fjorde indenfor disse findes i Almindelighed marint Ler og Dynd. De Laguneaflejringer, der ses mellem Rimmerne tæe Nord for Asaa, bestaar saaledes af brunt Dynd med en fattig marin Fauna og en Mængde Blade, bl. a. Egeblade. Dette Dynd naar til en Højde af $7.8 \mathrm{~m} \mathrm{o.} \mathrm{H}$. Tæt Syd for Asaa findes marint Ler til $8.1 \mathrm{~m}$, og svagt udviklede Erosionsterrasser til en Højde af $9.4 \mathrm{~m}$ o. H. Ret ofte hviler dette marine Ler, der har en Mægtighed af $5-6 \mathrm{~m}$, paa Tørvelag fra Fastlandstiden.

I den store Fjord, der har strakt sig mod Vest ind langs Gjeraa, og som ved et Sund mod Sydvest har staaet i Forbindelse med Limfjorden Øst for Nørresundby og Aalborg, er Faunaen længst ude mod Øst en temmelig rig Kattegatsfauna, men bliver mere og mere fattig, jo længere man kommer ind mod Vest; her er de marine Lag senere blevet dækkede af Tørvemoser af stor Udstrækning og Mægtighed. Ved Boringer er det marine Alluvium fulgt ikke alene ind gennem den store, brede »Gjeraa Fjord «, men ogsaa ind i tidligere, smalle Fjordarme, dels mod Nord til Dronninggaard, dels mod Nordvest og Vest forbi Langholt indtil ca. $1 \mathrm{~km}$ fra Aalborg-Sæby Landevej.

I den yderste Del af den tidligere Gjeraa Fjord findes Strandlinjer i en Højde af $9.1 \mathrm{~m}$ o. H. I den smalle Fjordarm, der naaede ind til Dronninggaard, fandtes ved Boring $1 \mathrm{~m}$ Tørv, derunder $5.7 \mathrm{~m}$ marint Ler, derunder $0.6 \mathrm{~m}$ Tørv og nederst Sand; det marine Ler naar indtil $8.8 \mathrm{~m} \mathrm{o.} \mathrm{H.} \mathrm{Ved} \mathrm{den} \mathrm{gamle,} \mathrm{meget} \mathrm{flade} \mathrm{og} \mathrm{ikke} \mathrm{synder-}$ lig iøjnefaldende Kystlinje ved Bolle Station, tæet Vest for denne Fjord, findes en lille Affaldsdynge fra den ældre Stenalder. Syd herfor, ude i Midten af den tidligere Gjeraa Fjord, har de marine Lag en Mægtighed af indtil $8 \mathrm{~m}$ og hviler ogsaa her i mange Tilfælde paa Fastlandstidens Tørvemoser, der ved Boringerne er paaviste indtil $2.3 \mathrm{~m}$ under Havets Niveau. I de smalle Fjordarme, der har strakt sig længst ind mod Vest og Nordvest, findes det marine Dynd til en Højde af $7-8 \mathrm{~m}$ og under lignende Lejringsforhold. I Engen Øst for Langholt er Lagfølgen saaledes $1.3 \mathrm{~m}$ Tørv, derunder $4.4 \mathrm{~m}$ marint Ler med Skaller, derunder $0.2 \mathrm{~m}$ Tørv og nederst Sand; Overfladen af det marine Ler ligger $7.5 \mathrm{~m} \mathrm{o}$. H. Hvor Vejen fra Lyngdrup passerer Engdraget, findes $3.3 \mathrm{~m}$ Tørv, derunder $0.2 \mathrm{~m}$ marint Dynd og nederst Sand. Overfladen af Dyndet ligger $7 \mathrm{~m} \mathrm{o.} \mathrm{H.}$

I det Sund, der mod VSV forbandt Gjeraa Fjorden med Limfjorden, er skalførende, marint Sand og Ler paavist ved en Række Boringer; de marine Lag dækkes her af $3-5^{1 / 2} \mathrm{~m}$ Tørv og naar til en Højde af $7.2 \mathrm{~m}$ o. H.

Efterhaanden som Gjeraa Fjordens Munding lukkedes af Strandvolde, og Landet hævedes, dannedes der paa den flade Kyst udenfor 
et stort Rimmesystem, der fra Gjeraa strækker sig mod SSV og S indtil Hals Mose SV for Ulsted. Langs Nordsiden af Hals Mose afskæres alle disse Rimmer ved en tydelig i $\emptyset-\mathrm{V}$ gaaende Kystlinje, der aabenbart i længere Tid har dannet Landets Sydkyst ud mod Limfjorden. Først senere, under Landets fortsatte Hævning, voksede ny, udenfor liggende Rimmer videre ud mod Syd, hvorved der tilvejebragtes saa meget Læ, at Strømmen kunde aflejre det medførte Strandsand paa det lave Vand udenfor. Herved opstod, i forholdsvis sen Tid, den store Flade mellem Hals, Ulsted, Øster og Vester Hassing. Paa lignende Maade voksede Landet ud fra Syd, og Limfjordens østlige Del indsnævredes saaledes til sin nuværende Bredde.

Under Landsænkningens Maksimum, før den store Sandflade ved Hals var dannet, strakte Havet sig ind til Højlandet ved Ulsted, Øster og Vester Hassing, saaledes at Kattegat her dannede en stor, aaben Bugt, der naaede helt ind til Bakkerne ved Nørresundby og Aalborg. Havet angreb den gamle Kyst saa stærkt, at der nu over lange Strækninger, f. Eks. ved Ulsted og Vester Hassing staar tydelige og stejle Kystskrænter. Den gamle Kystlinje ligger nu ved Ulsted $8.5 \mathrm{~m} \mathrm{o.} \mathrm{H.;} \mathrm{inde} \mathrm{i}$ en tidligere Bugt ved Staa findes marint Ler til $7.8 \mathrm{~m} \mathrm{o.} \mathrm{H}$.

Længst inde i den tidligere Aalborg Bugt, mellem Vester Hassing og Nørresundby, er de marine Lags Mægtighed meget varierende, idet der ude langs den nuværende Limfjord fandtes flade Banker af senglacialt Yoldialer, adskilt ved Render og dybere Partier. Efterhaanden som disse Banker ved Landets Hrvning naaede op imod Havfladen, ydede de saa meget Læ, at der imellem dem aflejredes Dynd og Ler med en Fjord- eller Lagune-Fauna. Langs Østsiden af den tidligere Nørresundby-Hvorup $\varnothing$ er Strandlinjerne derfor ogsaa forholdsvis svagt udviklede; paa sine Steder findes det marine Ler tæet inde ved den gamle Kyst og hviler i flere Tilfælde paa Tørvelag fra Fastlandstiden.

Paa Sydvest- og Vestsiden af den tidligere Nørresundby-Hvorup $\varnothing$ staar den gamle Kystlinje derimod meget tydelig i en Højde af $7.2-7.8 \mathrm{~m} \mathrm{o}$. H., og ved Foden af Kystskrænten findes paa en længere Strækning en bred Accumulationsterrasse af Strandgrus 6 $\mathrm{m}$ o. H.

Læs $\emptyset^{1}$ ) med omliggende, udstrakte Grunde bestaar af en flad Banke af senglacialt Yoldialer, paa hvilken der i Stenalderhavets Tid er aflejret Sand og Grus. Øens højeste Parti dannes af et tre-

$\left.{ }^{1}\right)$ A. Jessen. 1897. Kortblade Læsø og Anholt. Danm. geol. Unders. I. Række. Nr. 4. København. 
kantet, 6-11 m o. H. liggende Plateau, begrænset af Nordkysten, en Linje fra Vesterø Havn mod $S \varnothing$ til Byrum midt paa Øen og en Linje fra Byrum mod Nordøst til Kirkebugt. Mod SV, S og SØ skraaner Landet meget jævnt ned til Kysten, der her er saa flad, at det kan være vanskeligt at angive Grænsen mellem Land og Hav.

Direkte paa Yoldialeret findes der, saavel oppe ved Byrum som nede paa det flade Land mod Syd, en Mængde store, til Dels endog meget store Sten, der flere Steder, f. Eks. ved Byrum, ligger samlede som Stenrevler. Disse Sten maa antages at være bragte hertil med Drivis, allerede da Lerbanken under den senglaciale Landhævning naaede op mod Havfladen. I Fastlandstiden maa store Dele af Øen have ligget over Havet, men fra denne Tid findes ingen Aflejringer; samtlige Ferskvandslag er forsvundne, aabenbart skyllede bort under Litorina-Sænkningen. Da Stenalderhavet havde sin største Udbredelse, dækkede det Øen fuldstændigt. Under den derpaa følgende Landhævning naaede den ovenfor nævnte Stenrevle ved Byrum først op over Havet, og fra denne voksede der Strandvolde ud med NV og $\mathrm{N}$, hvortil der - da hele det trekantede, høje Plateau naaede op i Havfladen - sluttede sig Strandvolde i V-Ø langs Nordkysten. Senere udfyldtes Partierne mellem de stenede Strandvolde med fint Sand. Højden, hvortil de øverste Strandvolde naar, er $11 \mathrm{~m}$ o. H., men, som det fremgaar af det ovenfor sagte, kan dette Tal ikke angive hele Landhærningens Størrelse paa dette Sted. Op mod en Strandvold, ca. $1 \mathrm{~km} \mathrm{~N}$ for Byrum og i en Højde af $6-7 \mathrm{~m} \mathrm{o.} \mathrm{H.,}$ fandtes ved et Vejanlæg i Midten af forrige Aarhundrede et forvitret Skelet og henved en Snes velbevarede Tænder af en Kaskelot (Physeter macrocephalus).

Efter at den høje, nordlige Del af Øen var bleven hævet op over Havet, foregik Tilvæksten af Land hovedsagelig mod SV, S og SØ, og tilsyneladende meget jævnt; Strandvolde findes kun med store Mellemrum, og deres Materiale er langt mere finkornet end paa den høje Del af Øen. Endnu i det sidste Aarhundrede er der ved Tilsanding sket meget store Forandringer; Kystlinjen er paa Sydøst- og Sydvest-Kysten rykket mellem 200 og $300 \mathrm{~m}$ udad, og de fleste af de tidligere Holme Syd for Læsø er nu blevne landfaste med Hovedøen.

\section{Fra Hirshals til Svinkløv.}

Paa Vendsyssels Vestkyst fra Hirshals til Lønstrup er Forskellen mellem Stenalderhavets og Nutidens Kystlinje ikke stor. Den gamle Kyst kan følges paa hele denne Strækning som en ca. 10 m høj Skrænt, udenfor hvilken der under Landets Hævning er aflejret 
en indtil $1 \mathrm{~km}$ bred Bræmme af Sand og Grus. Saavel Strandgruset som Bakkefoden er oftest dækket af Flyvesand; paa enkelte Steder ses dog Havstokke med flade Strandsten 10-11 m o. H., og paa andre Steder er Foden af Kystskrænten maalt til $11-12 \mathrm{~m} \mathrm{o.} \mathrm{H.}$ Da Havets Angreb paa den gamle Kyst aabenbart er fortsat nogen Tid efter Sænkningens Maksimum, og da den derpaa følgende Aflejring af de stenede Havstokke er foregaaet under Landhævningen, kan de nævnte Tal ikke anvendes til Bestemmelse af hele Landhævningens Størrelse; denne fremgaar derimod af de S. 16 omtalte, indtil $14.9 \mathrm{~m}$ o. H. liggende Strandvolde paa Pynten ved Hirshals.

Fra Lønstrup til Løkken findes ingen ældre Kystaflejringer; den diluviale Bakkeø, Rubjergknude, naar med sine nøgne, stejle Skrænter helt ud til Havet og er stadig Genstand for stærk Erosion. Et Indtryk af, hvor meget Land, der paa denne Strækning er skyllet bort, faar man ved at betragte et detailleret Højdekort over Egnen. Det viser, at af Bakkeøen mellem Maarup og Rubjerg er nu kun den østlige Halvdel tilbage, og at det højeste Punkt, Rubjergknude, ligger netop i den nuværende Kystlinje. Hele den vestlige Halvdel af Bakkeøen er forsvundet, saaledes at det høje Land sandsynligvis har strakt sig 2-3 km længere ud mod Vest end i Nutiden. Sammenlignes Videnskabernes Selskabs Kort fra 1787 med Generalstabens 100 Aar yngre Kort, ses det, at Landtabet mellem Lønstrup og Maarup har været $100-150 \mathrm{~m}$ i disse 100 Aar, omkring Rubjergknude $150-200 \mathrm{~m}$ og paa et enkelt, fremspringende Punkt endog $250 \mathrm{~m}$. Tallene er dog kun omtrentlige, idet Kortenes Maalestok og mindre Forskelligheder ikke tillader en nøjagtigere Maaling. Det vilde imidlertid være i høj Grad urigtigt herfra at slutte sig til, hvor stort Landtabet har været i længere Tidsrum. En Mængde forskellige Faktorer gør sig da gældende, blandt andet Kystlinjens større eller mindre Tilbagerykning Nord og Syd for dette Sted, Beskaffenheden af Jordlagene, og om disse har været de samme i det Land, der er forsvundet, som i det, vi nu ser staa tilbage. Endvidere vil en ringe Hævning eller Sænkning af Landet og Havbunden kunne ændre Strømmen i saa høj Grad, at dens Virkninger paa Kysten slet ikke kan bedømmes paa Forhaand.

Ved Furreby Kirke, tæt $\mathrm{N} \varnothing$ for Løkken, træder det gamle, glaciale Højland tilbage og ses først igen ved den nuværende Kyst $4-5 \mathrm{~km}$ sydligere. Det mellemliggende Sletteland ved Løkken bestaar yderst af et ca. $2 \mathrm{~km}$ bredt Bælte af Strandsand, der er dækket af Tørv og Flyvesand. Saavidt det kan ses for det dækkende Flyvesand, er der en vis Regelmæssighed i Strandsandets og Tørvens indbyrdes Beliggenhed, der nærmest minder om flade Rimmer og Dopper. Tæt indenfor dette Parti findes udprægede Fjordaflejringer, 
marint Ler og Dynd, ikke alene i Overfladen, men til en Dybde af over $6 \mathrm{~m}$, og paa adskillige Steder hviler disse Lag paa Tørvemoser fra Fastlandstiden. Saadanne Forhold vilde imidlertid være utænkelige, saafremt det store Engdrag, der nu fører fra Kysten ved Løkken mod SSØ ind til Slettelandet ved Store Vildmose, tidligere havde været et Sund, gennem hvilket Limfjorden og den daværende Vildmose-Bredning havde staaet i Forbindelse med Skagerrak. Gennem et saadant Sund maatte der have løbet en saa stærk Strøm, at ikke alene enhver Aflejring af fint Materiale, Ler og planteførende Dynd, vilde være udelukket, men at ogsaa ældre, mindre modstandsdygtige Lag, f. Eks. Tørvelag fra Fastlandstiden, vilde være blevne ødelagte og skyllede bort.

Ved at sammenligne Faunaen i de hævede, marine Lag Sydøst for Løkken og omkring Store Vildmose med Kystfaunaen i Skagerrak og Vesterhavet, kom V. Nordmann ${ }^{1}$ ) til det Resultat, at Faunaen i de hævede Lag indenfor Løkken havde en udpræget Fjordkarakter, svarende til Dyrelivet i den nuværende Limfjords Bredninger, og at den intet havde med Skagerraks Fauna at gøre. Saavel Dyreresterne som Aflejringernes fysiske Beskaffenhed vidner derfor med største Tydelighed om, at den af Havet tidligere dækkede Strækning mellem Løkken og Vildemose ikke kan have været noget Sund med fri Forbindelse ud til Skagerrak, men har varet en fra den daværende Del af Limfjorden, »Vildmose-Bredningen " udgaaende Vig, der mod Nordvest ved Løkken har været afspærret fra Havet.

Da Leraflejringer fra denne Fjord ikke alene kan følges ud til Mundingen af Furreby Aa (Klostergrøft), men endogsaa træder frem i den direkte ud mod Havet vendende Skrænt paa en Strækning af 6-700 m N for Aamundingen, maa en Del af det Land, der i sin Tid afspærrede Fjorden fra Skagerrak, nu være forsvundet. Det lader sig derfor ikke afgøre, om det har været Stranddannelser i Lighed med den Tange, der beskytter f. Eks. Ringkøbing Fjord mod Havet, eller om det har været æeldre (glacialt) Land.

De marine Lag, der ses ved Mundingen af Furreby Aa og i Klinten $600 \mathrm{~m}$ Nord derfor, bestaar af skifret Ler og Dynd med talrige Molluskskaller, i Særdeleshed af Cardium; desuden findes der enkelte Ferskvandsskaller (Limnæa) samt Blade af Eg, Birk, Hassel og Bændeltang. Det er altsaa udprægede Fjorddannelser, aflejrede langt inde i en godt beskyttet Fjord med Vand af ringe Saltholdighed. En mindre, smal og stærkt forgrenet Sidefjord har fra Hovedfjorden

1) V. Nordmans. 1905. Bemærkninger om Molluskfaunaen; se A. Jessen. Kortbladene Aalborg og Nibe. Danm. geol. Unders. I. Række, Nr. 10. Side 145. 
strakt sig mod $\mathrm{N}$ og $\mathrm{N} \varnothing$ ind i Landet Øst for Furreby Kirke, mellem Landevejen og Kystèn; de marine Lag, der her overalt er dækkede af Tørv, har i den østligste Fjordarm en Tykkelse af $3-5 \mathrm{~m}$ og naar til en Højde af $8.2 \mathrm{~m}$ o. H. En anden Gren af denne lille Fjord har strakt sig mod Nordvest ud til den nuværende Kystlinje ved Kodalsrende, $1500 \mathrm{~m}$ N for Furreby Kirke. Her ude i Klinten ses et Lag af marint Dynd, tæt pakket med Cardiumskaller og over- og underlejret af Tørv; men iøvrigt veksler Lagfølgen noget, idet Skallaget tæt ved Bredden af den tidligere Fjord kan være delt i flere Lag med indskudte Tørvelag. Skallerne findes til en Højde af $8.3 \mathrm{~m}$ o. H. Saavel Lagserien som Faunaen viser, at man ogsaa her befinder sig ved den inderste Ende af en tidligere Fjord, og som allerede nævnt har det ved Boringer kunnet paavises, at det er en Gren af den Fjord, der kan følges fra Sydøst, fra Hjørring-Løkken Landevej, mod Nordvest ud til Kodal. Ogsaa Forholdene ved Kodalsrende viser, at der paa denne Del af Kysten maa være skyllet meget Land bort; yderligere vil man paa et Kort over Vendsyssel kunne se, at Kystlinjen fra Furreby Nord paa til Maarup i Virkeligheden er et Vandskel, idet alle Aaløbene her løber ude fra Kysten ind i Landet og danner Tilløb til Liver Aa.

Landhævningens Størrelse i denne Egn angives ikke alene ved den Højde, hvortil det marine Ler findes inde i de tidligere Fjorde, men ogsaa ved de gamle Strandlinjers nuværende Højde over Havet. Inde i de smalle Fjorde er Strandlinjerne dog oftest meget svagt udviklede eller dækkede af Tørv; enkelte er velbevarede, saaledes en tydelig Erosionsterrasse, der ved Landevejen NØ for Løkken kan følges langs Engen i en Højde af $9.5 \mathrm{~m} \mathrm{o.} \mathrm{H}$.

Fra Hovedfjorden mellem Vildmosen og Løkken strakte forskellige andre Sidefjorde sig ind i Højlandet baade mod Øst og Vest. Længst mod Nord naaede en bred Fjordarm ind mod SØ langs Klostergrøft til Klosterenge $\mathrm{S}$ for Børglumkloster; de marine Lag har her en Mægtighed af kun 2-3 m, og Faunaen deri er ret fattig. En anden Fjord strakte sig mod Øst ind mellem Vrensted og Tise og dækkede de nuværende Vitmose Enge. Ogsaa her er de marine Lag af ringe Mrgtighed, og Faunaen er en meget fattig Fjordfauna; foruden Molluskskaller indeholder det dyndede Ler Blade af Eg og hviler paa Fastlandstidens Tørvelag, der her indeholder Rester af Fyr.

Imod Vest har flere Fjorde strakt sig fra Hovedfjorden ind i Ingstrup-Saltum Højland, saaledes baade Nordvest og Syd for Ingstrup Kirke; under Tørv og Ferskvandsdynd findes her $2-3 \mathrm{~m}$ dyndet, marint Ler med Skaller og derunder atter Tørv.

Jo mere man nærmer sig Ryaa og den store Slette omkring Vildmosen, desto rigere bliver den marine Fauna, og samtidig tiltager 
Fjordaflejringerne i Mægtighed. I Egnen Vest og Syd for Tise Kirke har de marine Lag saaledes ofte en Mægtighed paa 8-12 m.

Den udstrakte Flade, der nu indtages af Store Vildmose og det omliggende Sletteland, har under Litorina-Sænkningens Maksimum været fuldstændig dækket af Havet. Paa Slettelandet mellem den egentlige Mose og Højlandet bestaar Overfladen dels af Strandsand, dels af skalførende, marint Ler, over hvilket der ofte ligger et tyndt Lag Strandsand. Inde under Vildmosens indtil $5 \mathrm{~m}$ mægtige Tørvelag er Undergrunden af lignende, vekslende Beskaffenhed, dog saaledes, at Lerbunden er overvejende mod Syd og Sydvest, Sandbunden mod Nord. Kystlinjerne rundt om den tidligere $»$ VildmoseBredning « er paa enkelte Steder meget iøjnefaldende, f. Eks. ved Tise Bakke; i Reglen viser de sig som lavere, men dog tydelige Kystskrænter, saaledes over lange Strækninger mellem Tise og Brønderslev, mellem Brændskov og Sønder Elkjær, mod Vest ved Jetsmark og flere Steder. Paa Grund af Tørvedannelsen langs Foden af Brinkerne er det ikke altid muligt at maale Strandlinjernes Højde nøjagtigt; mod Nord mellem Tise og Brønderslev ligger den gamle Kystlinje 8.5-9.0 m o. H., paa Østsiden af Vildmose-Bredningen, N for Sønder Elkjær, 8-8.5 m o. H., og mod Vest, paa Sydøstsiden af Jetsmark Højlandet, $7-7.5 \mathrm{~m}$ o. $\mathrm{H}$.

Højden, hvortil det marine Dynd og Ler findes, viser tilsvarende Tal, aftagende fra $\mathrm{N} \varnothing \bmod \mathrm{SV}$. I en smal Fjord, der mod Nord har strakt sig ind langs Østeraa, mellem Tise og. Brønderslev, naar det marine Ler til $7.2 \mathrm{~m}$ o. H. ; Laget har en Tykkelse af indtil $7^{1 / 2}$ m og dækkes af $1-6 \mathrm{~m}$ Tørv. Mod Øst, hvor Vildmose-Bredningen gennem et Sund mellem Hammer Bakker og Biersted Bakke har staaet i Forbindelse med Limfjorden, findes Strandlinjer $7.5 \mathrm{~m}$ o. H., og marint Dynd i nogle smaa, beskyttede Vige til en Højde af $7 \mathrm{~m} \mathrm{o.} \mathrm{H.} \mathrm{I} \mathrm{dette} \mathrm{Sund,} \mathrm{hvor} \mathrm{der} \mathrm{aabenbart} \mathrm{kan} \mathrm{have} \mathrm{løbet} \mathrm{en}$ stærk Strøm, og hvor der har været rigelig Tilgang af salt Limfjordsvand, er Faunaen i de hævede Lag meget righoldig; blandt andet findes der tæt Nord for Hvorup en gammel Østersbanke af stor Udstrækning. Usædvanlig er den Mægtighed, hvortil de marine Lag kan naa i dette Sund. Ved Hvorupgaard Station er der ved en Boring fundet ialt $27 \mathrm{~m}$ marint Ler og Sand med talrige Skaller, og i en Dybde af mellem 19 og $20 \mathrm{~m}$ under Overfladen endog et $0.3 \mathrm{~m}$ tykt Skallag, hovedsagelig bestaaende af Østers. Da det senglaciale Yoldialer faa Hundrede Meter derfra naar op til Markens Overflade, drejer det sig rimeligvis om en smal, dyb Rende, der er bleven udfyldt af Stenalderhavets Sediment.

Mod Sydvest har Vildmose-Bredningen staaet i Forbindelse med den tidligere Limfjords-Bredning omkring Gjøl og Øland ved flere 
Sunde, hvoraf det bredeste mellem Aaby og Jetsmark allerede i lange Tider har været kendt for sin rige Fauna. I den gamle Østersbanke ved Aastrup, ca. $1 \mathrm{~km} \mathrm{~N}$ for Aaby, er det egentlige Skallag ca. $2 \mathrm{~m}$ tykt; ude i Midten af det tidligere Sund, NV for Aastrup, har man ved Brøndgravning fundet et Skallag med en Tykkelse af henved $5 \mathrm{~m}$. I de tidligere Vige og Sunde ved Biersted, Syd for Vildmosen, findes marint Ler op til $6.8 \mathrm{~m} \mathrm{o}$. H. og til lignende Højde naar Strandgruset mellem Biersted og Aaby.

Fra Vildmose-Bredningen har der mod Vest strakt sig en bred Bugt ind mellem Jetsmark og Saltum. I Bugtens ydre, østlige Del har de marine Lag en Mægtighed af indtil $9-10 \mathrm{~m}$ og hviler paa meget dybtliggende Tørv fra Fastlandstiden; Faunaen, der her er ret righoldig, bliver fattigere og fattigere, jo længere man fjerner sig fra Vildmose-Bredningen. Et Sund har fra Bugtens indre Del strakt sig videre mod Sydvest mellem Jetsmark og Hune til den Lavning, der nu dækkes af Lundergaards Mose, og mod Nordvest har en Fjord naaet ind mellem Hune og Saltum; her dækkes de marine Lag dog af et saa tykt Lag Flyvesand, at dens Udbredelse ikke har kunnet fastslaas.

Af Betydning er det at se, at Faunaen i Vildmose-Bredningen er rigest mod Syd og Sydvest, i de Sunde gennem hvilke den har staaet i Forbindelse med den egentlige Limfjord; her findes de kendte, store Østersbanker og de rigeste Skallag. Ogsaa ude i den store Bredning har Dyrelivet været veludviklet og rigt saavel paa Arter som paa Individer. Men kommer man herfra ind i de Fjorde, der har strakt sig videre ud mod Øst, Nord eller Vest, f. Eks. i den Fjord, der naaede ud til den nuværende Kystlinje ved Løkken, er der en kendelig Forandring, der tyder paa mere brakt Vand. Bløddyrfaunaen faar her Præg af en fattig Fjordfauna med faa Arter og tyndskallede Individer og viser paa iøjnefaldende Maade, at Vildmose-Bredningen ikke kan have staaet i aaben Forbindelse med Skagerrak, men kun med Limfjorden.

Paa Vestsiden af Saltum-Hune Højlandet staar den gamle Kyst ud mod Skagerrak som en stejl Skrænt, der i meget minder om den gamle Kystskrænt fra Hirshals til Lønstrup. Skønt Kystlinjen her mod Syd paa mange Steder er dækket af Klitter, kan den dog følges som en næsten ret Linje paa en Strækning af over $10 \mathrm{~km}$. Nedbrydningen er senere, under Landhævningen, bleven afløst af en Tilvækst af Land, saaledes at der nu foran den gamle Kystskrænt ligger et lavt, af Klitter delvis dækket Forland, hvis Bredde vokser mod Syd. Udfor Blokhus har det saaledes en Bredde af $1 \mathrm{~km}$.

Omtrent $4 \mathrm{~km}$ Syd for Blokhus træder det diluviale Højland tilbage fra Kysten; herfra til de høje Bakker ved Tranum bestaar Lan- 
det udelukkende af postglaciale Lag, dækkede af store Mængder Flyvesand. Nærmest den nuværende Kyst findes paa denne Strækning udprægede Stranddannelser, som Regel Strandsand, sjældnere Strandgrus; indenfor dette Bælte ligger en af Flyvesand dækket, 1-3 km bred, meget flad Ryg, der fra Sydenden af Højlandet ved Hune strækker sig mod Sydvest til Bakkerne ved Tranum. Indenfor denne Ryg træffes f. Eks. Syd for Lundegaards Mose og ved Tranum Aa, Øst for Tranum, marine Lag af en helt anden Karakter, nemlig dyndet Ler med en fattig Fjordfauna. Længere ude paa det store Sletteland, der herfra breder sig mod Syd til Limfjorden, findes dels Strandsand, dels marint Ler, ofte ogsaa flade Banker af Yoldialer. Under de marine Lag er der endvidere paa en Del Steder paavist Tørvelag fra Fastlandstiden. Alt tyder paa, at der her i Stenalderhavets Tid har været et udstrakt, meget lavvandet Farvand, hvor Bølgeslag og Strøm ikke har kunnet spille nogen større Rolle. Jo nærmere man kommer den nuværende Limfjord, jo rigere bliver Faunaen; hist og her findes der endog Østersbanker, men overalt er det dog Limfjordstypen, der gør sig gældende, baade med Hensyn til de optrædende Arter og de enkelte Indviders Udvikling. V. NorDMANN har (anf. Sted Side 162) gennem faunistiske Undersøgelser godtgjort. at dette af Havet tidligere dækkede Sletteland Nord for Øland og Gjøl ikke kan have staaet i aaben Forbindelse med Skagerrak; det har ikke været noget Sund mellem Limfjorden og Skagerrak, men har været en tidligere Limfjords-Bredning, »Gjøl Bredning《, der - rimeligvis ved en Tange opbygget af Strandsand og Flyvesand - har været afspærret fra Skagerrak, hvad ogsaa Lejringsforholdene og Lagenes fysiske Beskaffenhed tyder paa.

Det er altsaa fuldstændig det samme Forhold, som (Side 23) omtaltes for Vildmose-Bredningens Vedkommende; men medens det beskyttende og afspærrende Land ved Løkken nu er omtrent forsvundet, har man aabenbart i den ovenfor nævnte Ryg mellem Hune og Tranum den Tange, der har beskyttet den indenfor liggende Gjøl Bredning mod Vesterhavet og tilladt Aflejring af Fjorddynd og fint Ler umiddelbart langs dens Øst- og Sydrand samt ude i Bredningen. Dannelsen af Revlen er sandsynligvis begyndt paa et ret tidligt Tidspunkt under Landsænkningen, hvorefter Bølgeslaget og Strømmen langs Kysten uafbrudt har bygget Revlen højere, i samme Grad som Landet sænkedes; det aabne Hav har derved til Stadighed lukket sig selv ude fra det lave Terrain indenfor, hvor Limfjorden lidt efter lidt bredte sig ud over Fastlandstidens Moser og Landoverflade.

Ude i Terrainet faar man ikke noget stærkt Indtryk af, at der findes en saadan Revle eller flad Ryg, idet omtrent alt er dækket af Flyvesand, der har givet Landskabet et helt andet Præg. Paa Højde- 
kortene kan man derimod, ved at se bort fra Klitterne, følge Revlen, hvis Østside viser sig at have været noget bugtet, medens dens Vestside har dannet en næsten ret Linje i Fortsættelse af den gamle Kyst ved Blokhus. Mod Sydvest støtter Tangen sig til Højlandet ved Tranum, og det er interessant at se, hvorledes Højlandet netop paa dette Sted har været beskyttet mod Havets Angreb, medens der umiddelbart Syd derfor, ved Bratbjerg staar en udprænget Kystklint, fremkommen ved Bølgeslaget i Gjøl Bredningen; og tæet Vest for det Sted, hvor Tangen har støttet sig til Højlandet, altsaa ud mod Jammerbugt, har Havets Erosion været saa voldsom og efterladt sig et saa imponerende Minde som kun faa Steder i Landet. Den indtil $50 \mathrm{~m}$ høje, meget stejle, gamle Kystklint strækker sig fra dette Punkt som en flad Bue forbi Lerup og Hjortdal Kirker mod Vest helt ud til Svinkløv; under Landhævningen er Erosionen bleven afløst af Accumulation, hvorved nyt Land voksede op foran den gamle Kyst; nu ligger der mellem denne og Jammerbugt en indtil $3 \mathrm{~km}$ bred, flad Slette af Strandsand.

Svinkløv, der bestaar af Skrivekridt med et Dække af glaciale Lag, har været et stærkt fremspingende Forbjerg, der har ydet betydelig Modstand mod Havets Angreb og derved været det nordvestlige Støttepunkt for Højlandet Syd herfor. Først i meget sen Tid er der foran Svinkløv aflejret saa meget Strandgrus, at Havet nu kun undtagelsesvis naar ind til Foden af de nøgne, hvide Kridtskrænter. Nutidshavstokken, der kun overskylles af Havet ved Vinterstorme, har ud for Slette Aa og Svinkløv en Højde af $3.1 \mathrm{~m} \mathrm{o.} \mathrm{H.}$

Da Erosionen paa de sidst omtalte Strækninger mulig har vedvaret til nogen Tid efter Landsænkningens Maksimum, behøver de fundne Strandmærker ikke at angive Havets højeste Niveau, og desuden har Flyvesandet dækket saa store Arealer, at det er ret tilfældigt, hvad der nu kan findes og maales. Omtrent midtvejs mellem Hune og Tranum findes ude paa den omtalte Tange foran den tidligere Gjøl-Bredning en Aflejring af Strandgrus ca. $8 \mathrm{~m} \mathrm{o.} \mathrm{H.,} \mathrm{og} \mathrm{ved}$ Mundingen af Slette Aa, $\mathrm{N}$ for Hjortdal Kirke, ses Grusterrasser $7.8 \mathrm{~m} \mathrm{o.} \mathrm{H}$.

\section{Fra Aalborg til Aggersund.}

Den nuværende Limfjord fra Hals til Thyborøn har i postglacial Tid undergaaet store Forandringer. Paa talrige Steder kan man ude i Fjorden og paa meget vekslende Dybde finde gamle Tørvemoser og Skovrester; ligeledes træffer man hyppigt ved Boring ned gennem de hævede, marine Lag paa ældre Tørvemoser eller andre Ferskvands- 
aflejringer som Sneglemergel eller lignende. Disse submarine eller under marine Lag liggende Tørvemoser og Ferskvandsaflejringer maa hidrøre dels fra Fastlandstiden, dels fra den første Del af Litorinatiden indtil det Tidspunkt, da Landsænkningen var saa vidt fremskreden, at vedkommende Sted drekkedes af Havet. Hvad der er fundet ved de forholdsvis faa Boringer, der er udførte i de hævede, marine Lag ved Limfjorden, er selvfølgelig ret tilfældigt og giver næppe den største Dybde, hvortil saadanne gamle Ferskvandsaflejringer findes; men de hidtil kendte Forekomster af disse Lag viser dog, at Limfjordsegnen maa have ligget adskillige Meter højere i Fastlandstiden end $\mathrm{nu}$, saaledes ved Aalborg mindst $6 \mathrm{~m}$ højere end $\mathrm{i}$ Nutiden.

Limfjorden maa altsaa i Fastlandstiden have haft et helt andet Udseende nu; de store, flade Strækninger med lavt Vand paa begge Sider af det dybe Sejlløb har været Land, og Løbet selv har været en smal, flodlignende Rende. Dennes Udseende faar man et Billede af ved paa Generalstabens Atlasblade (Maalestoksforhold $1: 40.000)$ at følge 2 Favne $(4 \mathrm{~m})$ Kurven i den nuværende Limfjord. Fra den store Løgstør (Livø) Bredning, hvor Havdybden er 6-10 $m$, fører en smal Rende ind mod Land, hvor Løgstør er bygget, og derfra videre gennem Aggersund; Renden har paa denne Strækning en Bredde af $50-100 \mathrm{~m}$ og en Dybde af $5-10 \mathrm{~m}$. Ca. $5 \mathrm{~km}$ Øst for Aggersund fører Renden ud i et Bassin, $1 \mathrm{~km}$ bredt, $4 \mathrm{~km}$ langt og med en Vanddybde af ca. 6 m, aabenbart en tidligere Sø. Øst herfor bliver Sejlløbet atter smalt og skarpt udskaaret, indtil det Sydvest for Øland deler sig i en smal nordlig og en bredere sydlig Rende, der omslutter en $3 \mathrm{~km}$ lang Banke, en tidligere $\varnothing$; Havdybden i Renden er her meget konstant 6-7 m. Ude i Nibe Bredning, Sydøst for Øland, er Renden paa en kort Strækning sandet saa meget til, at Dybden nu er mindre end $4 \mathrm{~m}$. Den største Del af Nibe Bredning er en overordentlig flad Strækning, der dækkes af $1 / 2-2 \mathrm{~m}$ Vand, og kun et mindre Parti, en tidligere Indsø, mellem Nibe og Gjøl har en Dybde af over $3 \mathrm{~m}$. Langs Randen af denne tidligere Indsø findes submarine Tørvelag, blandt andet Sydvest for Gjøl og ved Nibe. Da Nibe Havn anlagdes i 1866 fandtes der, ved Uddybning af Renden ind til Byen, Tørvelag, »hele Lag af forgaaet Skov* i en Dybde af $3.7-4 \mathrm{~m}$ under Havfladen.

Fra Nibe Bredning bliver Renden igen meget udpræget og kan nu uden Afbrydelse følges videre Øst paa forbi Aalborg til Hals. Vest for Aalborg er Bredden gennemsnitlig $300 \mathrm{~m}$ og Dybden 11-15 m; Øst for Aalborg er Renden oftest bredere, fra 400 indtil $600 \mathrm{~m}$, men Dybden er den samme, nemlig 11-15 m. Hvorledes Dybdeforholdene har været i Fastlandstiden, kan dog ikke direkte udledes af 
disse Tal, idet Bunden i Renden paa enkelte Strækninger bestaar af blødt, marint Dynd til stor Dybde. Dette iagttoges f. Eks. ved Aalborg ved Bygningen af Jernbanebroen, hvor fast Bund først fandtes $30 \mathrm{~m}$ under Fjordens Vandspejl. Saadanne dybe, kløftlignende Partier i Renden skyldes dog næppe Floderosion, men maa snarere sættes i Forbindelse med Spalter og Indsynkninger i det her optrædende Skrivekridt. Længst mod Øst ved Hals, hvor den nuværende Limfjord munder ud i Kattegat, findes et submarint Delta, idet Løbet deler sig i 3 Grene, der vifteformet skærer sig ud mod Sydøst og Syd mellem de der liggende, store Sandbanker, paa hvilke der, ved Anlæget af Fyret ud for Hals, ogsaa fandtes submarin Tørv.

Ud til Hovedløbet gennem den østlige Del af Limfjorden fører saavel fra Nord som fra Syd enkelte meget smalle Render, saaledes mellem Øland og Fastlandet, hvor en $5 \mathrm{~m}$ dyb Rende kan følges ind omtrent til Mundingen af den nuværende Tranum Aa; ved Nibe, hvor en 2-3 $\mathrm{m}$ dyb Rende fører Syd paa tæt forbi Byen til Sebbersund og aabenbart er en Fortsættelse af Halkjær Aa; og Nord for Egholm, hvor Renden med en Dybde af $3-5 \mathrm{~m}$ kan følges helt ind til Mundingen af den nuværende Ryaa. Disse Render, hvori der nu kun er ubetydelig Strøm, kan ikke være udgravede i nyere Tid, dertil er de for smalle og for dybe; de er uden Tvivl ligesom selve Sejlløbet gamle Flodrender, Tilløb til Hovedfloden. Men ejendommeligt er det, at de har kunnet holde sig saa skarpe og tydelige trods de siden Fastlandstiden meget vekslende geografiske Forhold, og at de ikke, i alt Fald under Landsænkningen i Stenalderhavets Tid, er blevet fyldte med marint Sediment.

Det bugtede Sejlløb, der danner en dyb, skarpt begrænset Rende mellem de omliggende flade Sletter, de endnu bevarede Tilløb fra Nord og Syd og det submarine Delta ved Hals viser, at man her, fra Løgstør Bredning til Kattegat, har bevaret et sænket, gammelt, men dog postglacialt Flodleje. Hvad man kender til Niveauforholdene og de geografiske Forhold i den senglaciale og postglaciale Tid, viser endvidere, at der kun i Fastlandstiden har været Mulighed for Eksistensen af denne store og utvivlsomt vandrige Flod, der kan kaldes Aalborg-Floden. I Fastlandstiden, da Egnen ved Aalborg laa mindst $6 \mathrm{~m}$ højere end $\mathrm{nu}$, og da de vestlige Limfjordsegne rimeligvis laa endnu højere, var Løgstør Bredning en stor Indsø, hvis sydlige Forgreninger var den nuværende Hjarbæk Fjord og Skive Fjord, og som mod Vest gennem Feggesund stod i Forbindelse med andre Søer, den nuværende Thisted Bredning, Kaas Bredning, o. s. v. Ved Fundet af dybtliggende, submarine Tørvelag i Østersøen og Nordsøen synes det godtgjort, at Landet i Fastlandstiden har ligget højere mod Syd og Sydvest end mod Nordøst; Følgen heraf har været, at 
de nævnte Indsøer med deres Tilløb Syd fra maa have haft deres Afløb, ikke til Vesterhavet, men mod Øst til Kattegat, og utvivlsomt gennem den daværende Aalborg-Flod fra Logstør Bredning til Hals. Denne Flod har da haft et Opland, der var langt større end det Opland, der hører til noget nuværende Vandløb i Danmark.

I Litorinatiden, da Landet sænkedes, bredte Stenalderhavet sig over det lavest liggende Terrain med dets Indsøer og Tørvemoser. Den vestligste Del af Limfjorden, Vest for Løgstør, stod da ved brede Sunde i saa aaben Forbindelse med Skagerrak, at Faunaen blev præget deraf. Samtidig var den østlige Del fra Hals ind til Aalborg at betragte som en stor, aaben Bugt fra Kattegat. Stenalderhavets "Limfjord «, karakteriseret ved forholdsvis smalle Forbindelser mod Øst og Vest til Kattegat og Vesterhav, og i Særdeleshed ved en Molluskfauna af omtrent samme Præg som i Nutidens Limfjord, strakte sig - som tidligere paapeget af V. Nordmann (anf. St. S. 163) egentlig kun fra Aalborg til Aggersund ved Løgstør. Selv paa denne korte Strækning var Fordelingen af Land og Hav i Stenalderhavets Tid vidt forskellig fra Nutidens. Nord for Nørresundby Øen førte et Sund ind til den S. 23 omtalte Store Vildmose-Bredning, der atter mod Sydvest ved det brede Sund mellem Aaby og Jetsmark stod i Forbindelse med den tidligere Gjøl-Bredning; denne strakte sig ind over det store Lavland Nord for Gjøl og Øland og var kun ved en lav (S. 27 omtalt) Sandtange skilt fra Jammerbugt. Ogsaa paa Sydsiden af den nuværende Limfjord var store Arealer dækkede af Havet, der naaede ind til Foden af det høje Land, og Fjorde strakte sig dybt ind i Højlandet saavel Syd for Aalborg som Syd for Nibe og længere Vest paa.

Mægtigheden af de Sedimenter, der afsattes i disse Bredninger og Fjorde, er gennemgaaende ikke stor og overskrider sjældent $6-7 \mathrm{~m}$. Paa en Mængde Steder er de ældre Lag, senglacialt Yoldialer, Moræneler og Skrivekridt, kun dækkede af et ubetydeligt Lag Strandsand; i Særdeleshed Skrivekridtet ses ofte liggende omtrent udækket ude i Strandengene, saaledes f. Eks. paa Gjøl, Øland, langs Sydranden af Højlandet Vest derfor, ved Nibe og flere Steder.

Højden, hvortil de marine Lag nu findes, er størst mod Øst og paa saadanne Steder, som har haft en meget aaben Beliggenhed. Paa den udsatte Vestside af Nørresundby Øen findes hævede Havstokke $7.8 \mathrm{~m}$ o. H., og den gamle Kyst staar Nordvest for Nørresundby som en stejl, meget iøjnefaldende Brink. I Vestenden af Nørresundby har der paa denne Kridtbrink ligget en Stenalders Affaldsdynge, der imidlertid nu er fuldstændig ødelagt og bortgravet. Omkring de tidligere Øer mellem Vadum og Biersted findes Strandlinjer indtil 7.0-7.5 m 
o. H., og i de beskyttede Vige mellem de tidligere Øer naar det marine Ler og Dynd til 6.3-6.9 $\mathrm{m} \mathrm{o}$. H. Den flade, kun et Par Meter høje Ø Egholm, Vest for Aalborg, har været fuldstændig dækket af Havet.

Øen Gjøl, der i Stenalderhavets Tid kun havde en Trediedel af sin nuværende Størrelse, laa meget isoleret ude i den store Bredning, og Stranddannelserne naar derfor ber op til forholdsvis stor Højde. Paa Nordsiden af den høje Del af Øen findes saaledes Strandvolde til $7.8 \mathrm{~m}$ o. H., og til samme Højde naar Strandstenene i en Accumulationsterrasse paa Vestsiden af den lille isolerede Banke »Bjerget«, der nu er bleven landfast med Gjøls Højland, men som i Stenalderhavets Tid laa et Par Kilometer Vest for Hovedøen. En lille Affaldsdynge paa Vestsiden af Gjøls Højland viser, at Øen har været beboet eller i alt Fald besøgt af Mennesker allerede i Stenalderen. Dyngen, der for største Delen bestaar af Østerskaller, ligger $7.7 \mathrm{~m} \mathrm{o.} \mathrm{H.,} \mathrm{alt-}$ saa netop ved den Højde, hvortil Bølgeslaget kunde naa under Sænkningens Maksimum. Ligeledes vidner de talrige Flintredskaber, der findes langs Bakkefoden ude paa »Bjerget» om Stenalderfolkets Færden paa denne lille Holm.

Øland, hvoraf kun det centrale, høje Parti og en lille Banke, Knudebjerg, ragede op over Stenalderhavet, laa mere i Læ af Højlandet mod Vest; Stranddannelserne er derfor ikke saa kraftigt udviklede her som paa Gjøl, dog vidner de stejle Bakkeskrænter ud mod Lavlandet om en ret betydelig Erosion. Erosionsterrassen paa Øens Vestside ligger $6 \mathrm{~m}$ o. H., og en Strandvold paa Østsiden naar op til $6.3 \mathrm{~m}$ o. H. Ogsaa paa denne $\varnothing$, paa dens tidligere Sydkyst, findes et Par, hovedsagelig af Østersskaller bestaaende Affaldsdynger, liggende et Par Meter over Stenalderhavets Kystlinje.

Nordvest for Øland har den smalle Højderyg, hvorpaa Brovst By og Gaarden Bratskov ligger, været en $\varnothing$, adskilt fra det store, vestligere Højland ved et smalt Sund. Dette Sund har aabenbart ydet gode Betingelser for Molluskfaunen, idet der her foruden marint Ler, fyldt med Skaller, findes en righoldig Østersbanke, $1 \frac{1}{2} \mathrm{~m}$ mægtig. Paa Sundets Vestside, netop ovenfor denne Østersbanke, findes en $30 \mathrm{~m}$ lang, $10--15 \mathrm{~m}$ bred og $0.3 \mathrm{~m}$ tyk Affaldsdynge fra Ældre Stenalder. Dyngen, der overvejende bestaar af Østersskaller, og som desuden indeholder en Del Flintredskaber, bl. a. Skivespaltere, ligger 7-10 m o. H. Omtrent i samme Højde findes der overfor paa den anden Side af Sundet en mindre Affaldsdynge af lignende Beskaffenhed som den vestlige. Underlaget for de marine Aflejringer nede i det tidligere Sund er dels Ferskvandskalk, dels Tørv med Levninger af Fyr. Nordvest for dette Sund har en Fjord strakt sig ind mellem 
Tranum og Øster Svenstrup, hvor den har delt sig i flere Grene; de marine Lag ses dog ikke, idet de dækkes af ret betydelige Tørvelag.

Den mod Øst ud mod den tidligere Gjøl Bredning vendende Side af Højlandet har været udsat for stærk Erosion, og Stranddannelser findes til betydelig Højde. Ved den nordøstlige Side af Bratskov Øen ligger der en stor Accumulationsterrasse af Strandgrus med en Højde af $7.2 \mathrm{~m} \mathrm{o}$. H. I Sundet Vest for Bratskov Øen, altsaa paa et mere beskyttet Sted, findes lange, smalle Strandvolde parallelt med Kysten; deres Højde er kun 6-6.6 m o. H. Sydvest herfor, N for Torslev, har de stenede Strandvolde ligeledes en Højde af $6.6 \mathrm{~m}$, og i Læ af dem findes marint, skalførende Ler til $5.3 \mathrm{~m} \mathrm{o}$. H. Syd for Torslev ligger Foden af den gamle Kystklint, der til Dels bestaar af Skrivekridt, kun 5.6-5.8 m o. H. Kommer man derimod om paa Sydvestsiden af den Halvø, der fra Torslev og Øster Svenstrup har strakt sig Syd paa, er Stranddannelsernes Højde adskilligt større. Ved Alsbjerg, SV for Torslev, staar den gamle Kyst som en 12. m høj, stejl Skrænt, ved hvis Fod der ligger en bred, stenet Strandvold $6.3-6.6 \mathrm{~m}$ o. H.

Herfra og Vest paa til Aggersund er. Stenalderhavets Kystlinje ikke synderlig iøjnefaldende; hverken Erosion eller Accumulation har været af Betydning, og højtliggende Stranddannelser mangler. Først paa Nordsiden af Aggersund, Øst for Aggersborg Kirke, findes større, stenede Strandvolde, hvis Højde er indtil $6 \mathrm{~m} \mathrm{o.} \mathrm{H.,} \mathrm{og} \mathrm{i}$ samme Højde ligger Erosionsterrassen i Højlandet indenfor.

Langs Sydsiden af Limfjorden mellem Aalborg og Aggersund var Landets Kystform i Stenalderhavets Tid ligeledes en væsentlig anden end nu. Største Delen af Aalborg By er bygget paa gammel Havbund i Mundingen af en tidligere Fjord; Bunden, der for en Del bestaar af dyndet, skalfyldt Ler, er paa mange Steder saa blød, at den vanskeligt kan bære Vægten af Bygningerne. Langs den ydre Del af denne tidligere Aalborg-Fjord er de gamle Kystlinjer endnu meget iøjnefaldende, f. Eks. SØ for Byen ved Blegkilde, hvor der har ligget en Affaldsdynge fra den ældre Stenalder; Fjorden, som mod Syd har strakt sig dybt ind i Landet, og som ved flere Sunde Øst paa har staaet i Forbindelse med Kattegat, skal omtales nærmere under Beskrivelsen af Strækningen fra Aalborg til Mariager Fjord. Ogsaa Vest for Aalborg har det brede, lavtliggende Forland foran Bakkerne været dækket af Havet; den gamle Kystklint staar meget stejl og tydelig fra Kasted i Vestenden af Aalborg mod Sydvest og Syd forbi Hasseris By til Sydenden af den tidligere Hasseris $\varnothing$. Klintens Fod ligger her ca. $6 \mathrm{~m}$ o. H., og længst mod Syd findes Stranddannelser til $6.6 \mathrm{~m}$ o. H. Imod Vest forbi Store Restrup, 
hvorfra der kendes en Affaldsdynge fra den ældre Stenalder, kan den gamle Kyst følges, snart tydeligt, snart omtrent skjult under Tørvelag, i en Højde af ca. $6 \mathrm{~m}$ o. H. En tæt Nordøst for Store Restrup liggende, ejendommelig Grusryg, der med en Længde af 6-700 m, en Bredde af $30-100 \mathrm{~m}$ og en Højde af $14 \mathrm{~m}$ forbinder Højlandet med en Nord derfor liggende plateauformet Banke, der har samme Højde som Grusryggen, er ikke nogen postglacial Strandvold, men er rimeligvis af senglacial Alder. I en Højde af $6-7 \mathrm{~m}$ kan Stenalderhavets Kystlinje følges omkring den høje Banke Nørholm, der har ligget ret isoleret ude i den tidligere Limfjord; paa Nørholm Øens Sydvestside, der har været udsat for det kraftige Bølgeslag i Nibe Bredning, findes Strandvolde og Banker af Strandgrus indtil $7.2-7.5 \mathrm{~m}$ o. $\mathrm{H}$.

En lige saa aaben og udsat Beliggenhed har den tidligere Kyst haft Sydvest herfor ved Mundingen af Binderup Aa og videre forbi Nibe til Sebbersund. Den gamle Kyst tegner sig paa denne Strækning meget skarpt; de tidligere Kystklinter, der for en Del bestaar af Skrivekridt, hæver sig stejlt op fra den gamle Havbund, de nuværende, flade Strandenge. I de tidligere Aamundinger og paa lignende Steder, hvor Strømmen har kunnet aflejre det Materiale, som Bølgeslaget brød løs andre Steder, findes ofte store Mængder af Strandgrus. Hvor Landevejen passerer Binderup Aa, ses saaledes Strandvolde med mere end haandstore Sten, der naar til $5.6-6.0 \mathrm{~m}$ o. H. Noget vestligere findes mindre tydelige og af Flyvesand delvis dækkede Strandvolde af senglacial Alder, hvor Strandgruset naar til $8^{1 / 2} \mathrm{~m} \mathrm{o.} \mathrm{H.}$

Sydvest for Nibe findes paa Østsiden af Sebbersund et stort System af Strandvolde, hvor Strandgruset naar til $6.3 \mathrm{~m} \mathrm{o}$. H. Ogsaa paa Vestsiden af Sebbersund er saavel Stenalderhavets Kystlinje som hævede Stranddannelser smukt udviklede. Midt i den tidligere Fjord har den $30 \mathrm{~m}$ høje Banke Sct. Nicolai Bjerg ligget som en lille Holm med stejle Kyster, udsat for stærk Erosion. Det udskyllede Grus aflejredes paa Nordsiden af Banken og ligger nu som en bred, flad Strandvold, der nærmest den tidligere $\varnothing$ naar til 5.3-5.6 m o. H. og længere mod Nord ved Valsted By til $4.7 \mathrm{~m}$. Vest herfor kan den gamle Kystlinje følges fra Valsted til Sebberkloster i en Højde af ca. $6 \mathrm{~m} \mathrm{o.} \mathrm{H.,} \mathrm{og} \mathrm{udenfor} \mathrm{er} \mathrm{der} \mathrm{ved} \mathrm{Sebber} \mathrm{Skole,} \mathrm{NV} \mathrm{for} \mathrm{Sct.}$ Nicolai Bjerg, aflejret en stor Grusterrasse med ægstore Strandsten og med en Højde af 5.6-6.0 m o. H. Umiddelbart ovenfor den gamle Kystlinje, i en Højde af mellem 6.3 og $7.8 \mathrm{~m} \mathrm{o}$. H., ligger der ved Skolen en Affaldsdynge fra den ældre Stenalder. Stranddannelserne paa Sundets Vestside ligger, som det ses, noget lavere end paa dets Østside, hvad der aabenbart staar i Forbindelse med Beliggenheden 
i Forhold til den overvejende Vindretning fra Vest, et Forhold der iøvrigt ogsaa kan iagttages paa mange andre Steder.

Den nuværende Fjord indenfor Sebbersund naar kun ca. $4 \mathrm{~km}$ mod Syd, og Indløbet er kun en smal Rende, hvorover Landevejen fra Nibe er ført paa en Bro. I Stenalderhavets Tid var Indløbet til Fjorden et Par Kilometer bredt, og Fjorden strakte sig langt mod Syd; de marine Lag, dækkede af et Par Meter Ferskvandslag, kan følges Syd paa indtil NØ for Aars. I den ydre Del af den tidligere Fjord var Faunaen temmelig righoldig; ved Hedegaard, $6 \mathrm{~km} \mathrm{~S}$ for Sebbersund er der fundet en Affaldsdynge fra den ældre Stenalder. Længere Syd paa blev Faunaen fattigere, men endnu saa sydligt som ved Veggerbro, NV for Skivum, findes dog talrige Molluskskaller i de gamle Fjorddannelser. Lagfølgen er her $1.9 \mathrm{~m}$ Tørv og Sand, $4 \mathrm{~m}$ marint Ler og Dynd og derunder groft Sand.

Længere Vest paa, mellem Sebbersund og Aggersund, har en anden stor og bred Fjord strakt sig langt ind i Landet, indtil $2-3 \mathrm{~km}$ Syd for Nibe-Løgstør Landevej. I den tidligere. Fjords ydre Del, de store Strandenge $\varnothing$ for Næsborg, ses de marine Lag overalt, og den gamle Kystlinje er her som oftest meget tydelig, i alt Fald paa Fjordens Østside, hvor Erosionen har været stærkest. Saaledes har f. Eks. den ejendommelige, kegleformede, $40 \mathrm{~m}$ høje Banke, Marbjerg, der har ligget som en lille Holm i Fjordens Munding, været meget udsat for Havets Angreb og hæver sig nu med en meget stejl Vestside op ovẹr den tidligere Havbund. Længere mod Syd er de marine Lag dækkede af Tørv, og Mosedannelsen har fuldstændig skjult den gamle Kystlinje.

Længst mod Vest ved Aggersund findes smukke Strandvolde, der som et vifteformet System af Grusrevler strækker sig fra Færgestedet Øst paa. Her, hvor Bølgeslaget næppe har været saa stærkt, er Højden kun 5-5.3 m o. H. Syd for Færgestedet, paa Vestsiden af Landet, naar Strandgruset derimod til 6.3-6.6 $\mathrm{m} \mathrm{o.} \mathrm{H.;} \mathrm{disse}$ Stranddannelser er imidlertid aflejrede af den store Løgstør Bredning og staar altsaa ikke i Forbindelse med den i dette Afsnit behandlede »Stenalders-Limfjord *.

\section{Vester Hanherred og nordlige Thy.}

Skønt denne Del af Landet har en saa udsat Beliggenhed ud mod Skagerrak og Vesterhavet, og skønt Størrelsen af den postglaciale Landhævning har været stærkt aftagende fra Øst til Vest og Sydvest, har Tilvæksten af Land siden den ældre Stenalder dog været usædvanlig stor, for enkelte Strækningers Vedkommende endog større, 
i Forhold til det gamle Land end i Vendsyssel. Paa den anden Side er det vanskeligt at bedømme, hvor meget Land der samtidig eller senere er skyllet bort, men noget betydeligt Areal er det næppe; efter alt at dømme har Landvindingen siden den ældre Stenalder (Affaldsdyngernes Tid) været mange Gange større end Tabet af Land — til Trods for Vesterhavets og Skagerraks saa meget omtalte og saa meget overdrevne Virksomhed.

Grunden til dette Forhold ses let paa medfølgende Kort. Ved den postglaciale Landsænkning, der fulgte efter Fastlandstiden, og ved hvilken betydelige Landarealer efterhaanden dækkedes af Havet, var der opstaaet ejendommelige Kystformer. Vestkysten af Thy var paa Stenalderhavets Tid bugtet og fliget, og udenfor den egentlige Kystlinje laa enkelte Forposter, mindre Holme og Skær. Øst for Thisted var Landet opløst i en Mængde større og mindre Øer, spredte mellem hinanden, og uden at der hverken i Øernes Form eller indbyrdes Beliggenhed var nogen som helst Tilpasning til det omgivende Hav og dets Kræfter. Saa unaturlige Forhold kunde ikke opretholdes i synderlig lang Tid; Havet maatte naturnødvendigt ved Hjælp af de store Kræfter, der stod til dets Raadighed, søge at tilvejebringe en Grænse mellem sig og Landjorden, hvor Erosion og Accumulation saa nogenlunde holdt hinanden i Ligevægt. Mod Vest og Nord angreb det de yderste Skær; adskillige af disse er utvivlsomt fuldstæendig forsvundne; af andre er der endnu smaa Rester tilbage, medens atter andre, der bestod af Kridt og Kalk, bedre kunde holde Stand mod den voldsomme Brænding. Samtidig lagde Strømmen Barrer og Revler fra Pynt til Pynt og fra Ø til Ø, og i Læ af disse Barrer aflejredes ind mod Limfjorden det fineste Sand og Leret, hvorved Vige og Sunde efterhaanden udfyldtes. Idet Landet samtidig hævedes, tørlagdes paa denne Maade store Strækninger, Kystlinjerne fik efterhaanden jævne og bløde Former, og de enkelte Øgrupper samledes til større Landmasser.

Det er saaledes først og fremmest Strømmen langs Kysten og dernæst Landhævningen, der har bevirket den nuværende Fordeling af Land og Hav. Strømmen brød ned paa de udsatte Punkter, flyttede Materialet i Strømretningen og aflejrede det i Læ af Pynter og Øer; eller den skar sig ned i Havbunden og satte Sandet ind paa Kysten. De uhyre Mængder Sand, der siden den postglaciale Sænknings Maksimum er aflejrede som Strandsand og sekundært som Flyvesand i det nordlige og vestlige Thy, maa vistnok antages for en stor Del at hidrøre fra Vesterhavets Bund.

Strømmen langs Jyllands Vestkyst er en Følge dels af Ebbe og Flod, dels af Vinden. Flodbølgen rammer Vestkysten omtrent ved den nordlige Ende af Ringkøbing Fjord; herfra løber Flodstrømmen 
dels mod Syd til Blaavandshuk, dels mod Nord forbi Thyborøn, Hanstholm og rundt om Skagen ind i Kattegat. Ebbestrømmen løber modsat Vej. Den af Vinden frembragte Strøm, Stryget, der opstaar, idet Vandmasserne med vestlige Vinde presses fra Atlanterhavet ind i Nordsøen, er dog ofte langt stærkere og afgørende for Strømretningen langs Kysten. Resultatet af mange Aars Iagttagelser er da, at fra Stenbjerg, lidt Syd for Vorupør paa Vestkysten af Thy, og til Skagen foregaar Materialvandringen fra Syd mod Nord, og fra Stenbjerg til Blaavandshuk fra Nord mod Syd.

Det store Højland, der fra Aggersund strækker sig mod Nord over Fjerritslev til Svinkløv og mod Øst til Tranum og Torslev, har paa sin Nord- og Vestkyst været stærkt udsat for Havets Angreb. Nordkysten af denne tidligere $\varnothing$, fra Tranum til Svinkløv, er allerede omtalt (Side 28). Længst mod Nordvest har Svinkløvs hvide Kridtklinter gennem lange Tider staaet som et Forbjerg ud mod Skagerrak; først efter at Landet var hævet omtrent til sit nuværende Niveau, aflejredes der saa meget Sand og Grus foran Klinten, at den beskyttedes mod Bølgeslaget. Den var herefter udelukkende udsat for den almindelige Vejrsmuldring, som i Aarhundredernes Løb har givet den sin nuværende, karakteristiske Form.

Fra Svinkløv kan den gamle Kyst følges som en stejl Skrænt mod Syd og Sydvest til Fjerritslev. Mod Nord er Skræntens Højde ca. $30 \mathrm{~m}$; det rindende Vand har udgravet skarpe, dybe Dale i den, og Flyvesandet, der dækker Lavlandet mod Vest, er med sine uregelmassige Klittoppe vandret op over Skrænten og op paa Højlandet. Dette lyngdækkede Landskab, der er saa ejendommeligt ved sin Storslaaethed og sine vekslende Former, er endnu saa uberørt af Nutidens Kultur, at man umiddelbart faar Indtryk af de forskelligartede Kræfter, der har omformet Landet siden Stenalderhavets Tid.

Nedenfor den høje Skrænt, ca. ${ }^{1 / 2} \mathrm{~km}$ fra Kysten, findes et Lag Skalgrus, skyllet sammen paa den daværende Strand og bestaaende af stærkt rullede Skaller og Skalfragmenter. Højden, hvortil Skalgruset findes, er 7.8-8.1 $\mathrm{m}$ o. H.; Nutidshavstokken udenfor naar til en Højde af $3.1-3.4 \mathrm{~m}$ o. H. Da Skalgruset er skyllet sammen ved Foden af en stærkt eroderet Kystskrænt, er det næppe aflejret under Litorina-Sænkningens Maksimum, men snarere lidt senere, under den følgende Tids Landhaevning.

Mod Sydvest hen imod Fjerritslev bliver Landet lavere, og den gamle Kyst er mindre iøjnefaldende. Nedenfor Skrænten findes dog paa mange Steder Revler af Strandsten. Hvor den gamle Kystlinje omtrent ved Aalborg-Thisted Landevej tager en mere sydlig og sydøstlig Retning, har Strømmen ført Grus og Sand videre ud i den 
oprindelige Retning mod Sydvest; noget ældre er et System af Strandvolde, der udgaar fra den tidligere $\varnothing$ ved Gjøttrup, og som fra dennes Nordende breder sig vifteformet ud mod Nord og Nordøst. Disse Strandvolde, der bestaar af æeg- til haandstore Sten, danner lange, smalle Rygge, hvis Højde mod Syd er $7.8 \mathrm{~m}$, noget nordligere ca. 7 m o. H. Efterhaanden som Landhævningen skred frem, voksede de fra Fjerritslev udgaaende, yngre Strandvolde videre mod Sydvest indtil $\mathrm{V}$ for Gjøttrup Kirke, hvor de nu danner et bredt System af $5 \mathrm{~m}$ høje Strandvolde, Gjøttruprimmer. Paa den tidligere $\varnothing$ ved Gjøttrup, ligesom paa den sydligere liggende, mindre $\varnothing$ ved Bjergegarde, har Havets Erosion været stærkest paa Nord- og Vestsiderne, der danner stejle Skrænter, til Dels bestaaende af Limsten, og hvorfra Materialet til Strandvoldene er taget.

Vest herfor breder den hævede Havbund sig som en stor, flad Slette, der kun afbrydes af Klitterne og af nogle isolerede Banker, tidligere Øer i Stenalderhavet. Østligst findes en saadan $\emptyset$ ved Klim, derefter Torup Øen og længst mod Nordvest den høje, tidligere Ø Nord for Vust, hvis nordligste Punkt er det bekendte Bolbjerg.

Medens Underlaget for de løse, kvartære Jordlag ved Svinkløv og Fjerritslev er Skrivekridt, bestaar de næunte tre, tidligere Øer for en Del af Limsten. Øen ved Klim har for en Del ligget i Læ bag den vestligere liggende Torup $\varnothing$, og Erosionen har derfor været ret ubetydelig undtagen paa Nord- og Nordøstkysten. Her staar den gamle Limstensklint høj og stejl, og her brydes og udsaves Limstenen. Foden af Skrænten er dog dækket af Flyvesand, saa at de gamle Kystlinjer er skjulte; derimod findes Øst og Syd for Kirken, altsaa paa Læsiden af den tidligere $\varnothing$, et System af stenede Strandvolde, der nærmest Højlandet har en Højde af $5.3 \mathrm{~m}$ og længere mod Syd $4-4.7 \mathrm{~m}$ o. H.

Ved Torup fandtes der under Landsænkningens Maksimum en større nordlig og en mindre sydlig $\varnothing$, forbundne ved Revler af Strandgrus med sammenskyllede Strandskaller. Disse Revler ligger nu 5-5.3 m o. H. Den nordlige $\varnothing$ bestaar af høje Limstensbanker, Stenbjerg og Kløv, der staar med stejle Klinter ud mod Vest og Nord, hvor Havets Angreb har været stærkest. I Kløv er der nu smaa Brud i Limstenen. De gamle Strandlinjer er her, ligesom paa Nordenden af Klim Øen, skjulte under Flyvesandet.

Bolbjerg Øen, der er den største og højeste, har ligget overordentlig udsat for Havets Angreb. I Særdeleshed under Stenalderhavets Maksimumudbredelse har Havet virket med voldsom Kraft mod dette, den Gang langt fremspringende Forbjerg. I Begyndelsen maa Nedbrydningen være skredet meget hurtig frem, men efter at Havet havde bortført det gennem Aartusinders Vejrsmuldring løsnede 
Materiale og var naaet ind til den faste Limstensklippe, saavel i Bolbjerg som i Skareklit, ydedes der stærkere og stærkere Modstand. Det er derfor umuligt, med Klintens nuværende, aarlige Tilbagerykning som Udgangspunkt, at slutte sig til, hvor lang Tid der er forløbet, siden Skareklit var en Del af det faste Bolbjerg.

Ved Sydenden af Bolbjerg Øen aflejrede den nordfra kommende Strøm saa meget Sand og Grus, at den flade Banke, hvorpaa Vust nu ligger, blev forbundet med Hovedøen. Syd for Vust førtes Gruset videre ud mod Syd og Sydvest og aflejredes som et stort System af Grusrimmer, hvis Højde er 4.7-5.3 m o. H. En Del af Strandgruset paa dette Sted har faaet Anvendelse ved Bygningen af FjerritslevThisted Banen, blandt andet til Jernbanedæmningen over Lund Fjord. I et af de herved fremkomne Profiler i Strandgruset, paa et Sted, hvor dette naaede til $3.5-3.7 \mathrm{~m}(11-12 \mathrm{Fod})$ o. H., fandtes, i Følge V. Nordmann $\left.{ }^{1}\right), 1.9-2.5 \mathrm{~m}(6-8$ Fod $)$ under Overfladen Takker af Kronhjort og Knogler af Hest og Tamokse. Knoglerne, der var stærkt rullede, laa $\mathrm{i}$ fint Sand med Tang og maa oprindelig være aflejrede paa Stranden eller paa lavt Vand; de er derefter blevet dækkede af Strandgrus, og ved den fortsatte Landhævning bragt op i deres nuværende Niveau. Da de fundne Knogler af Hest og Tamokse i det tidligste kan stamme fra Broncealderen, slutter Norduann, »at i det nordlige Danmark var den sidste Hævning i alt Fald ikke afsluttet i Broncealderen «.

De ovenfor anførte Tal giver et betydeligt Spillerum for Bestemmelsen af den Højde over Havet, hvori Knogler og Takker fandtes, nemlig $0.9-1.9 \mathrm{~m} \mathrm{(3-6 \textrm {Fod } )}$ o. H. Denne Højde vilde angive Landhævningens Størrelse siden Broncealderen, saafremt Knoglerne oprindelig var aflejrede netop i Kystlinjen ved Middelvandstand. Er de aflejrede udenfor Kystlinjen eller kastede op paa Strandbredden, maa Tallene henholdsvis forhøjes eller reduceres. Noget bestemt Maal for Landhævningens Størrelse siden Broncealderen giver dette Fund altsaa ikke; men at der er foregaaet en Hævning, fremgaar af den Højde, 3.5 -3.7 m o. H., hvortil det dækkende Strandgrus naar. Strandvoldene ved Vust er nemlig ikke dannede ved en aaben Skagerrakkyst, idet Grusrevler allerede paa et langt tidligere Tidspunkt var voksede ud fra Bolbjerg mod Sydvest og havde skabt Læ mod vestlige og nordvestlige Vinde, og mod Øst har Sundet mellem Bolbjerg-Partiet og Kløv utvivlsomt ogsaa været helt eller delvis lukket ved Grusrevler. Strandgruset ved Vust har under disse Forhold næppe kunnet kastes op til større Højde end $2^{1 / 2} \mathrm{~m}$ over Middelvandstand, saaledes at

$\left.{ }^{1}\right)$ V. Nordmann. 1905. Danmarks Pattedyr i Fortiden. Danm. geol. Unders. III. Række, Nr. 5. Kjøbenhavn. Side 90. 
Landhævningen siden Broncealderen rimeligvis maa sættes til ca. $1 \mathrm{~m}$ paa dette Sted.

Vestsiden af Bolbjerg og af dettes Fortsættelse mod Syd, Troldsting, staar med en stejl, 20-30 m høj Skrænt, et Vidnesbyrd om den voldsomme marine Erosion i Stenalderhavets Tid. Umiddelbart efter Sænkningens Maksimum maa dog Aflejringen af Strandgrus foran den gamle Klint være begyndt. Den store Slette Vest for Bolbjerg bestaar tilsyneladende kun af Flyvesand, men enkelte Steder findes der dog Revler af Strandgrus og flade, afrundede Strandsten. Saaledes ligger der $1.8 \mathrm{~km}$ SV for Bolbjerg en udpræget, stenet Strandvold ved den Vej, der fra Lild og Nørklit fører ud til Kysten. Dens Højde er 9.4 m o. H. Efter Beboernes Udsagn vil man overalt paa Sletten kunne finde Strandgrus (Havør), der ligger som lange, smalle Revler med Retning $\mathrm{N} \varnothing-\mathrm{SV}$; mellem Grusrevlerne er der rent Sand, og Gruset dækkes som oftest af $1 / 2-1 \mathrm{~m}$ Flyvesand.

Den nævnte Højde, 9.4 m, hvortil Strandgruset findes, er forbavsende stor; dog maa det erindres, at paa den nuværende Kyst ud mod Skagerrak kaster Havet Strandsten op til 3.2-3.7 m over Middelvandstand (i Følge »Danske Lods« endog over almindeligt Højvande), og ringere har Bølgernes Kraft ikke været i Stenalderhavets Tid. En anden Maalestok maa derimod, som ovenfor berørt, anvendes ved Bedømmelsen af de Stranddannelser, der aflejredes paa Syd- og Østsiden af de daværende Øer eller i Læ af den yderste Ørække. Her er den Højde, hvortil Bølgeslagets Virkning har naaet, langt ringere end ud mod det aabne Hav, og vil være afhængig af Vanddybden foran Kysten samt af Stedets mere eller mindre aabne Beliggenhed, i Særdeleshed i Forhold til vestlige (sydvestlige og nordvestlige) Vinde.

Sydvest for Bolbjerg Øen findes nogle høje Banker, tidligere Øer, hvis Vestsider staar som stejle, $15-25 \mathrm{~m}$ høje Brinker, der ligger i Forlængelse af hinanden i Retning NNØ-SSV, drejende til NØ-SV. Flyvesandet har nu dækket Bakkernes Fod, og de Stranddannelser, eller der efter al Sandsynlighed aflejredes langs den daværende Kystlinje som Revler mellem Øerne, er nu skjulte. Gaar man fra Foden af en af disse tidligere Øer, f. Eks. »Bjerget», hvorpaa Lild Kirke ligger, ud mod VNV, falder Terrainet paa den første Kilometer fra en Højde af 9 til $6.3 \mathrm{~m}$ o. H. Det danner her en $1^{1 / 2}-2 \mathrm{~km}$ bred, trugformet Lavning, hvori der findes en Række langstrakte Klitsøer, parallele med den indenfor liggende, gamle Kyst. Derefter stiger Terrainet atter mod Vest til ca. $11 \mathrm{~m}$ o. H. og danner en henved 2 km bred, flad Højderyg; herfra har Overfladen et meget jæunt Fald paa de sidste $1 \frac{1}{1} 2-2 \mathrm{~km}$ ud til den nuværende Kyst. Den flade Højderyg, der løber fra Nø til SV, kan følges omtrent fra Lildstrand, 
V for Bulbjerg, en halv Snes Kilometer mod Sydvest, hvorefter den bøjer mod Syd til det høje Land, den tidligere $\varnothing$ ved Tovsig, i Vesløs Hede. Højderyggen er saa regelmæssig og har saa konstant Højde, at den næppe udelukkende kan skyldes Flyvesandet; sandsynligvis bestaar den af Strandvolde og Grusrevler, hvorover Flyvesandet i sin Tid har lagt sig som et jævnt, 2-3 m tykt Dække, og mulig er den en Fortsættelse af det i NØ-SV løbende System af indtil 9.4 $\mathrm{m}$ høje Strandvolde, der som ovenfor omtalt findes paa Sletten Vest for Bulbjerg (se desuden Side 43).

Den iøjnefaldende Udbugtning, som den ellers saa retlinjede $\mathrm{Nu}$ tidskyst danner ved Lildstrand, $3 \mathrm{~km} \mathrm{~V}$ for Bulbjerg, skyldes de haarde og modstandsdygtige Bjergarter, der her naar omtrent frem til Jordoverfladen. Ved de Boringer, der foretoges paa Sandnæshage i Anledning af Anlæget af Vestkysthavnene ${ }^{1}$ ), fandtes den faste Kalksten, Limsten, i en Dybde af $4 \mathrm{~m}$ under Havets Niveau, dækket af Sand, Grus og Rullesten. Endvidere ligger der $2^{1 / 2} \mathrm{~km}$ fra Kysten et Rev, Bragerne, der bestaar af store Kalkstensflager og derunder vistnok af faststaaende Limsten, og som nu dækkes af kun 2-3 $\mathrm{m}$ Vand. Sandsynligvis er disse Kalkstensrev Rester af tidligere Øer, der er blevet ødelagte ved Havets voldsomme Angreb, men som dog baade under Landhævningen og senere har haft Betydning som faste Støttepunkter for Strømmens Aflejring af Sand og Grus og dermed for Kystlinjens Beliggenhed.

Indenfor den yderste Række af tidligere Øer har der ligget en langstrakt $\varnothing$ og nogle mindre Holme, det nuværende Hannæs. Indtil for nylig var Hannæs en lang, smal Halvø, mod Øst begrænset af Bygholm Vejle og Selbjerg Vejle, mod Vest af Vesløs Vejle og Tømmerby Fjord; ved Anlæget af de store Dæmninger tværs over Fjordmundingerne og delvis Udtørring af Vejlerne har hele Landskabet skiftet Karakter, dog maaske nok saa meget paa Kortet som i Naturen.

Baade paa Øst- og Vestsiden har Hannæs Øen været udsat for stærk marin Erosion, og hævede Strandmærker findes paa mange Steder. Gennem Tømmerby kan den gamle Kystlinje følges over en lang Strækning som en stor Erosionsterrasse ca. $6 \mathrm{~m} \mathrm{o}$. H. Sydligere, mellem Tømmerby og Vesløs Gaard, findes stærkt eroderede, gamle Kystskrænter og i disses Fortsættelse Strandvolde, der er lagt tværs over den indenfor liggende Lavning. Disse Strandvolde langs Østsiden af Tømmerby Fjord er nu delvis ødelagte ved den

$\left.{ }^{1}\right)$ Betænkning afgiven af den af Ministeriet for offentlige Arbejder den 25. Juni 1914 nedsatte Kommission vedrørende Anlæg af Fiskerihavne m. m. paa Jyllands Vestkyst. København. 1916. 
stærke Grusgravning; længst imod Syd ved Hybjerg har Strandvoldene inde ved Banken en Højde af $6.3-6.6 \mathrm{~m} \mathrm{o.} \mathrm{H.,} \mathrm{og} \mathrm{tæt} \mathrm{Nord}$ derfor har den øverste Strandvold, paa hvis Ryg der ligger en Gravhøj, en Højde af 6.6 m o. H. Fra denne Strandvold skraaner Grussletten mod Vest jæunt ned mod Landevejen, og paa denne Skraaning staar der i en Højde af $4-5.5 \mathrm{~m} \mathrm{o}$. H. nogle til Dels velbevarede Skibssætninger. Syd herfor, langs Vestsiden af Hybjerg, findes en iøjnefaldende Erosionsterrasse 6.3 m o. H. Længere mod Sydvest kan Kystlinjen følges gennem Vesløs By i en Højde af ca. 6 m o. H.

Østsiden af Hannæs Øen staar for største Delen som en brat Kystskrænt, der er særdeles tydelig ved Selbjerggaard S for Tømmerby Kirke, ved Højstrup og mod Syd ud ad mod Feggesund. Erosionen maa paa hele denne Strækning have vedvaret til meget sen Tid, idet Klinternes Fod kun ligger et Par Meter over Havet. Derimod findes gamle Havstokke til betydelig Højde omkring de tidligere Smaaøer Øst for Hannæs, NØ for Øsløs. Fra Hannæs Øen udgaar en smaastenet Strandvold, $4.7 \mathrm{~m}$ o. H., til Nordenden af den vestlige af Øerne, Lyngbjerg, hvis Nordende staar med stejl Kystklint. Herfra strækker der sig videre mod Øst til Nordenden af den østlige $\varnothing$, Thorsbjerg, en anden stor og smukt formet Strandvold, ganske vist noget forhøjet ved Flyvesand, men hvori Strandgrus naar til $6.3 \mathrm{~m} \mathrm{o}$. H.; i Strandvoldens nordlige Skraaning er der gravet meget Grus. Østsiden af Thorsbjerg staar som en stejl Kystklint, i hvis Fortsættelse mod Syd Strømmen har aflejret betydelige Mængder af Strandgrus. Umiddelbart Øst for Gravhøjen paa Sydenden af Lyngbjerg ses en lille Affaldsdynge ca. $7-7.5 \mathrm{~m}$ o. H.; den indholder Mæengder af store Østerskaller, desuden Cardium, Litorina og enkelte Pecten. Affaldsdyngen, hvori der ikke er foretaget nogen Gravning, men som i Følge sin Beskaffenhed maa antages at hidrøre fra den ældre Stenalder og at være samtidig med Stenalderhavets største Udbredelse, ligger ved Roden af en stor, flad Strandvold, der herfra strækker sig Øst paa med en Højde af $5.6 \mathrm{~m}$ o. H. Syd herfor findes en Række smalle Strandvolde ca. $5 \mathrm{~m}$ o. H., og mod Nordvest løber endnu en Strandvold, temmelig kort, men med en Højde af $5.6 \mathrm{~m}$ o. H. Paa denne Egn findes i det hele taget en usædvanlig stor Mængde Strandgrus. Ogsaa mod Vest udgaar der fra Lyngbjergs Sydende en stor, bred Strandvold, der afspærrer Øsløs Sundet mod Syd.

Paa Nordsiden af den nu delvis udtørrede Tømmerby Fjord findes ved Langvad en tidligere $\varnothing$, der ved et temmelig bredt Sund har været adskilt fra Hannæs Øen. Trods de betydelige Mængder af Flyvesand, der er gaaet hen over Langvad Øen, er den dog meget fremtrædende i Terrainet, idet dens Nordside staar som en retlinjet, indtil $15 \mathrm{~m}$ høj, stejl Skrænt, der danner en Fortsættelse mod Sydvest 
af de Side 40 nævnte høje, stejle Bakkeskrænter ved Lild Kirke. Medens Øens stejle Nordvestside vidner om stærk marin Erosion, har de andre Sider aabenbart ligget i Læ for Bølgeslaget, idet de skraaner jævnt ned mod Lavlandet.

Paa en mellem Langvad og Østerild liggende, tidligere $\varnothing$, ved Tovsig paa Vestsiden af Tømmerby Fjord, er Kystkonturerne af en anden Karakter. Paa Ostsiden findes der ud mod Lavlandet omkring Tømmerby Fjord flere mindre Kystklinter; derimod viser Nordvestsiden af den tidligere $\varnothing$ intet som helst Tegn paa marin Erosion, skønt Øen tilsyneladende har ligget lige saa udsat for nordvestlige Vinde som de NØ herfor liggende, tidligere Øer. Grunden hertil maa rimeligvis søges i den Side 40-41 nævnte, flade Højderyg, der fra Sletten Vest for Bolbjerg og Lild kan følges et Stykke mod Sydvest og derefter mod Syd, hvor den netop støder til Nord- og Vestsiden af den tidligere Tovsig $\varnothing$. Saafremt det er rigtigt, at Grundlaget for denne Højderyg ogsaa mod Syd er hævede Havstokke, er det ikke usandsynligt, at disses Aflejring her er begyndt allerede under Landsænkningen, og at deres Vækst er foregaaet efter samme Maalestok som denne, saaledes at der stadig Nord og Vest for Tovsig Øen har ligget Strandvolde, der beskyttede Banken mod Bølgeslaget.

Hele den udstrakte Slette mellem Bolbjerg i Nordøst, Østerild i Syd og Vigsø i Nordvest er gammel Havbund og Stranddannelser, der nu for største Delen er dækkede af Flyvesand.

Fra Østerild og Lønnerup Fjord har der mod Nordvest til Hanstholm strakt sig en Ørække, der ved et snart smallere, snart bredere Sund har været adskilt fra den Sydvest derfor liggende Hovedø Thy. Da der i dette Sund har været en baade stadig og stærk Tilførsel af salt Vesterhavsvand og dog samtidig noget Læ for Bølgeslaget, har Stenalderhavets Fauna her kunnet udvikle sig til stor Rigdom saavel paa Arter som paa Individer. Hævede Skallag, ofte hele Østersbanker, af betydelig Udstrækning og Mægtighed findes derfor nu paa mange Steder i dette Terrain.

Medens Vestsiden af den sydligste af de tidligere Øer, Lønnerup Øen, har været udsat for stærk marin Erosion i Stenalderhavets Tid og nu staar med stejl Skrænt ud mod de lave Enge, har Nord- og Østsiden ligget mere i Læ; her er der derimod aflejret Stranddannelser af betydelig Udstrækning. Saavel i en NV for Østerild Kirke i $\mathrm{N}-\mathrm{S}$ løbende Strandvold, der naar til $6.3 \mathrm{~m} \mathrm{o}$. H., som i andre af Strandvoldene ved Østerild findes talrige, opskyllede Molluskskaller, bl. a. af Østers. Disse Revler af Strandgrus og Skalgrus har gennem lange Tider været anvendle som Vejmateriale. Øst herfor, langs Landevejen gennem $\varnothing$ sterild Klit, findes næsten overalt Strandgrus 
som smaa, rimmelignende Volde $4.7-6.0 \mathrm{~m} \mathrm{o}$. H. Største Delen er dog skjult under et Dække af Flyvesand.

Lønnerup Øen har ved et smalt Sund været skilt fra den Nord derfor liggende Hjardemaal $\varnothing$ eller, som den kaldes, Østholmen. Saavel ved Øst- som ved Vestenden af dette Sund har Strømmen ført Grusmasser ud, der som Strandvolde efterhaanden har afspærret Sundet og forbundet de to Øer. Den vestlige Strandvold, NV for Hunstrup Kirke, danner en smal Grusryg, paa hvilken Landevejen er ført over Kæret; trods sin ringe Højde, $4.7 \mathrm{~m} \mathrm{o.} \mathrm{H.,} \mathrm{træder} \mathrm{Strand-}$ volden meget tydeligt frem i Terrainet som Modsætning til de omgivende, flade Enge. Ved den anden Ende af Sundet er der fra Hjardemaal Øens Sydøstside vokset et System af Strandvolde ud mod Sydøst og Syd, hvor de forenes med de tidligere nævnte Havstokdannelser ved Østerild. Disse Strandvolde er dog dels udviskede, dels stærkt forhøjede ved paafløjet Flyvesand.

De to nordligste Øer, Hanstholmen og Østholmen (Hjardemaal Øen) har en meget ejendommelig Form. Begge Øer er langstrakte, deres Langsider danner parallele, omtrent rette Linjer, og Siderne er paa de fleste Steder meget stejle. Skrænternes Højde varierer paa Østholmen fra 10 til noget over $20 \mathrm{~m}$; paa Hanstholmen er de noget højere, fra 20 til $30 \mathrm{~m}$, og paa en kort Strænkning paa Nordkysten har Skrænten endog en Højde af $45 \mathrm{~m}$. Den nederste Del af Hanstholmen bestaar at Skrivekridt, derover findes Danien-Aflejringer, fortrinsvis Blegekridt, og øverst glaciale Aflejringer. Fra Hjardemaal Øen, Østholmen, kendes kun Blegekridt, men det er muligt, at der ogsaa her i Bakkefoden vil kunne findes Skrivekridt. Overfladen er noget bølget, men dog ikke mere, end at »Holmene« paa Afstand, ude fra Sletten, ligner et Par store, flade Klodser med skarpt afskaarne Sider.

At tyde disse Kridtøers Form udelukkende som Resultatet af den marine Erosion, vil næppe være rigtigt. Paa Hanstholmen er der saaledes ikke nogen Forskel paa de Skrænter, der har været mest udsat for Havets Angreb, og de Skrænter, der har ligget i Læ; Nord-, Syd-, Øst- og Vestskrænterne er alle lige stejle og danner den skarpeste Modsætning til Terrainformerne i Højlandet $2-3 \mathrm{~km}$ Syd herfor, paa den anden Side af det tidligere Sund; her, hvor den marine Erosion næppe kan have været ret meget ringere end paa Hanstholmen, har Bakkesiderne bløde, afrundede Former, og de rette Linjer mangler, saaledes at Stenalderhavets Kystlinje bugter sig ud og ind. Hertil kommer, at f. Eks. ved Bjerre (Bjerget) paa Hanstholmen ligger Foden af den bratte Skrænt ca. $20 \mathrm{~m}$ o. H., altsaa langt over den Højde, hvortil Havet har naaet, og nedenfor Skrænten findes en jævnt skraanende Flade, paa hvilken Gaardene i Byen Bjerre er byg- 
gede. Endvidere har det (efter mundtlig Meddelelse af Ingeniør J. Fibiger, sml. Vestkysthavne-Kommissionens Betænkning) ved Forundersøgelserne i Anledning af Bygningen af en Havn ved Helshage vist sig, at Havbunden her ud for Hanstholm Pynten ikke bestaar af det bløde Skrivekridt, der findes i den nederste Del af selve Hanstholmen, men af en haard Kalksten, der angives at minde om det Dække af Kalksten (Danien), der ligger over Skrivekridtet i Hanstholmen, og at det ude i Havbunden er yderst vanskeligt at bore i og endog har en Haardhed, der minder om Saltholmskalkens.

Der synes derfor at være god Grund til at antage, at disse Holme med deres karakteristiske Begrænsning, deres nordvest-sydøstlige Retning og deres fra det øvrige Højland i Thy meget afvigende Udseende oprindelig har faaet deres Form bestemt ved Brudlinjer i Jordskorpen. De maa vistnok betragtes som et Par Horste, idet de omgivende Partier er sænkede. Trods lange Tiders Vejrsmuldring og den stærke marine Erosion paa dette Sted, et af de mest udsatte Punkter paa Danmarks Kyster, har Holmene i Hovedsagen beholdt den ved Brudlinjerne bestemte Form.

Da Havets Angreb paa de gamle Kyster har vedvaret ret langt ned i Tiden, og da Flyvesandet senere har dækket den hævede Havbund, ses kun faa Strandaflejringer fra Stenalderhavets maksimale Udbredelse, men blandt disse Stranddannelser er en Strandvold ved Kaas paa Sydsiden af Hjardemaal Øen ogsaa ualmindelig storslaaet. Strømmen, der har løbet fra NV mod Sø, er ved en ringe Drejning af Kysten ført i en Bue ud fra denne og har derved aflejret det medførte Grus som en »Hale«, hvis Retning først er fra Nord mod Syd, senere mod SØ parallel med Kysten, og hvis Højde aftager fra Roden ud mod Spidsen. Volden er jævnt skraanende paa den ydre, vestlige Side og stejl paa den indre Side. Rullestenene i Volden er oftest flade, afrundede Sten af den sædvanlige Vesterhavstype, og Materialet er for en stor Del Blegekridt fra. Hjardemaal Øen. Нøjden, hvortil denne Strandvold naar, er $7.8 \mathrm{~m} \mathrm{o.H.,} \mathrm{altsaa} \mathrm{usædvan-}$ lig stor. Da Vesterhavet ved Hanstholm i Nutiden kan kaste Strandsten op til en Højde af mellem 3.5 og $3.8 \mathrm{~m}$ over Middelvandstand, vil man her igennem kunne slutte sig til en Landhævning paa ca. 4 m for dette Punkt.

Efterhaanden som Landhævningen skred frem, blev Hanstholmen og Østholmen forbundne ved Sand- og Grusrevler; senere indsnævredes og lukkedes det Sund, der skilte Holmene fra den Syd derfor liggende store $\varnothing$ Thy. De fleste af disse yngre og lavere liggende Havstokaflejringer er nu skjulte under Flyvesandet eller dækkede af Kærmoser, men enkelte Steder kan de dog endnu eftervises. Dette gælder f. Eks. om det System af Strandvolde, der forbandt de to 
Holme, og som efterhaanden voksede ud mod Syd, over mod Thy. Disse Strandvolde viser sig nu som et af Flyvesandet stærkt medtaget, men dog let genkendeligt Rimmesystem, der fra Sydøstenden af Hanstholmen breder sig vifteformet mod Sydøst og Syd.

\section{Vestlige og sydlige Thy. Mors.}

De lavtliggende Enge og Flyresandsstrækninger, der fra Lønnerup Fjord strækker sig mod Nordvest til Hanstholm, har som ovenfor nævnt været et Sund, der har skilt det sydlige Thy fra den i det foregaaende Afsnit beskrevne, tidligere Øgruppe mellem Hanstholm og Fjerritslev. Sundets nordøstlige Side træder overordentlig tydelig frem i Terrainet; de gamle, høje Kystskrænter staar endnu saa stejle og retlinjede, som om de var skaarne ud med en Kniv. Som Modsætning hertil danner den tidligere Kyst langs Sundets Sydvestside en bugtet Linje med bløde Bakkeformer, og kun undtagelsesvis finder man tydelige Kystskrænter. Paa flere Steder er det endog meget vanskeligt at paavise den gamle Kystlinje; det gælder i Særdeleshed Strækningen mod Nordvest mellem Tved og Rær, hvor saa store Mængder af Flyvesand er vandret ind over Landet, at de oprindelige Landkonturer er udviskede. Den paa Kortet angivne Kystlinje maa derfor paa denne Strækning kun betragtes som omtrentlig. Længere mod Sydøst er der derimod ingen Tvivl om, hvor Grænsen mellem Land og Hav har gaaet; mellem Kaastrup og Lønnerup Fjord hæver de gamle Kystskrænter sig endog stejlt op fra de foranliggende, store Tørvemoser og Enge, hvor de talrigt forekommende Skaller af marine Mollusker angiver, at det er gammel Havbund. Kysten har her været bugtet og indskaaret og af en helt anden Type end Kysten langs Hanstholmen og Østholmen. Blandt andet har en smal Fjord strakt sig fra den nuværende Lønnerup Fjord langt ind $\mathrm{i}$ Landet forbi Momtoft og Kjeldstrup til hen imod Hillerslev.

Østkysten af Thy har i Stenalderhavets Tid haft omtrent samme Kystform som i Nutiden. Noget, men næppe meget Land maa antages at være skyllet bort, og et Par mindre Fjorde er nu tørlagte. Ejendommeligst er den smalle Fjord, der fra Vilsund har strakt sig $3-4 \mathrm{~km}$ mod Nord, parallelt med den nuværende Limfjordskyst, og kun adskilt fra denne ved en $1-1^{1} / 2 \mathrm{~km}$ bred Bakkeryg, paa hvilken Byen med det betegnende Navn Aas ligger. Andre, mindre Fjorde fandtes Syd for Visby og Øst for Heltborg ved Næs Sund. Det højtliggende Boddum Sogn var i Stenalderhavets Tid en Ø Nord for Thyholm, men er nu bleven landfast med Thy. Det tidligere Sund, 
der skilte Boddum Øen fra Thy, og som var meget smalt, fremtræder endnu overordentlig tydeligt, begrænset paa begge Sider af $30-40 \mathrm{~m}$ høje Bakker. Da Landet hævedes, lagde en Strandvold sig tværs over Sundet, hvor dette mod Syd munder ud i Skibsted Fjord; men for at forklare Beliggenheden af de store Grupper af Broncealders Gravhøje Ø og SØ for Ydby maa man antage, at den nordlige Del af Sundet endnu saa sent som i Broncealderen har været sejlbar Nord fra, fra Doverkil, og saa langt Syd paa som til Horshøj, hvor Landevejen fra Ydby til Boddum nu passerer Engdraget. Strandvoldene paa Sydsiden af den tidligere Boddum Ø har som Følge af den meget beskyttede Beliggenhed kun en Højde af $3.7 \mathrm{~m} \mathrm{o.} \mathrm{H.}$

Paa Vestsiden af Thy er der foregaaet store Forandringer siden Litorina-Sænkningens Maksimum; saavel Kystformen som Landets Udstrækning er nu en ganske anden end den Gang. Gennemgaaende maa Kystlinjen i Stenalderhavets Tid have ligget ca. $5 \mathrm{~km}$ indenfor (Øst for) den nuværende Kyst, men foran Hovedlandet fandtes adskillige Holme, der som en Skærgaard brød noget af Havets Magt, og som senere - under Landets Hævning - virkede som Støttepunkter for det af Strømmen aflejrede Grus og Sand. Selv om adskillige af disse Holme efterhaanden er blevne et Offer for Havets Erosion og nu næppe kan paavises, har de dog haft deres Betydning for Kystformen og for den store Landvinding paa Vestkysten af Thy.

Længst mod Nord laa Hanstholms Kridt- og Kalkklinter som et langt fremspringende Forbjerg. Syd derfor var Kystens Retning indtil Nors Sø omtrent Nord-Syd. Der er paa denne Strækning gaaet uhyre Mængder af Flyvesand ind over Landet, men de gamle Kystklinter, der delvis bestaar af Kridtformationens Bjergarter, har været saa høje og stejle, at de endnu paa lange Strækninger træder tydeligt frem i Klitlandskabet. Ved Højlandets Fod har Flyvesandet opdæmmet en Række Søer; da disse og den omgivende Sandslette ligger $\mathrm{i}$ en Højde af $15-16 \mathrm{~m}$ o. H., er selvfølgelig alle Havstokdannelser skjulte under Sandet.

Det synes, som om Kystlinjens Retning i dette Terrain paa enkelte Strækninger er bestemt ved gamle Brudlinjer eller Sprækker i Kridtet. Fra Neder Hindinggaarde ved det nordlige Hjørne af Nors Sø kan man følge en saadan Linje $5 \mathrm{~km}$ direkte mod Nord; i sin nordligste og sydligste Del viser Brudlinjen sig som smalle Dale med stejle Sider. Den nordlige Dal har rimeligvis i Stenalderhavets Tid været et Sund, men muligt forekommende marine Lag er nu dækkede af Flyvesandet; Brinkerne langs Dalens Østside hæver sig meget stejlt $15 \mathrm{~m}$ op over Dalbunden. Det midterste Parti af Linjen, indenfor Blegsø, er mindst udpræget; men da netop denne Strækning, og kun denne, har været direkte udsat for Vesterhavets Erosion, er 
det et Vidnesbyrd om, at de stejle Brinker Nord og Syd derfor ikke kan skyldes Havets Angreb. Linjens sydligste Del nærmest Nors Sø er en smal Sprækkedal, der til Trods for den Mængde Flyvesand, der halvvejs har fyldt Dalen og dækket dens Sider, dog har et fra vore almindelige Dale meget afvigende Præg.

Mellem de to Lavninger, der nu indtages af Nors Sø og Vandet Sø, løber den gamle Kystlinje omtrent fra Øst til Vest som en iøjnefaldende og stejl Skrænt, der vistnok for en Del bestaar af Skrivekridt. Vest for Vandet Sø har det gamle Land skudt sig ud mod Nordvest til Boelsande som en Halvø, udenfor hvilken der har ligget en eller flere Holme. Dog kan den tidligere Kystlinje fra Vandet Sø, uden om Boelsande og Syd paa til hen imod Vang Kirke kun angives i grove Træk, idet store Mængder af Flyvesand her er gaaet ind over Landet og nu ligger som mægtige Klitter baade foran den gamle Kyst og oppe paa det høje Land. Udenfor Boelsande ses den tidligere Ø Vegebjerg, hvis højeste Punkt ligger $33 \mathrm{~m} \mathrm{o.} \mathrm{H.,}$ $17 \mathrm{~m}$ over den omgivende Slette. Denne tidligere Holm, der har Form af en retvinklet Trekant, har ejendommeligt nok jæunt skraanende Sider mod Vest og Syd ud mod det aabne Hav, hvorimod den mod Nordøst vendende Side, der har ligget mest beskyttet mod Havets Angreb, staar som en skarpt skaaret meget stejl Skrænt. Denne i NV-SØ løbende Skrænt, der ikke udelukkende kan være fremkommet ved marin Erosion, maa sandsynligvis, ligesom adskillige af de $\mathrm{i}$ det foregaaende omtalte Terrainformer, skyldes et Brud og en Sænkning i Kridtformationens Bjergarter, hvis Niveauforhold i denne Egn i saa høj Grad afspejler sig i Overfladens Terrainformer.

NNV for Vegebjerg ligger Pynten Ørhage ved Klitmøller. Grunden til denne tilsyneladende umotiverede Udbugtning af den ellers saa retlinjede Nutids-Kystlinje er en tæt op til Overfladen ragende Banke af Skrivekridt. Ved de i Anledning af Anlæget af Vestkysthavne foretagne Boringer fandtes der ude paa Ørhage Pynten blødt Kridt med Flint $\mathrm{i}$ en Dybde af kun $4 \mathrm{~m}$ under Havets Niveau. Østpaa synker Kridtoverfladen; $300 \mathrm{~m}$ Øst for Pynten ligger den saaledes ved $\div 17.6 \mathrm{~m}$, og her boredes der $\mathrm{i}$ Løbet af 1 Time ikke mindre end 9.4 m ned i Kridtet. Endnu østligere har man boret $32 \mathrm{~m}$ ned i »blød Kalkmasse«. At man her er truffet paa det bløde, flintfattige Skrivekridt, maa anses for givet. Fra Ørhage udgaar der ifølge »Danske Lods« i nordvestlig Retning et Rev af Sten, der ligger paa Ler, og paa hvilket der $300 \mathrm{~m}$ fra Land kun er $1 \mathrm{~m}$ Vand; ved Lavvande kan det endog ligge tørt.

Denne Del af Jyllands Vestkyst ligger meget udsat for vestlige og nordvestlige Vinde, og af og til kan maaske endog Atlanterhavsbølger naa ind hertil (sml. Vestkysthavne-Kommissionens Betæenk- 
ning); Nutidshavstokken har derfor en Højde af henved $4 \mathrm{~m}$ o. H. I »Danske Lods« skrives om denne Kyststrækning: „Vandet kan undtagelsesvis stige 2 à $2.5 \mathrm{~m}$, det overskyller da hele Strandbredden lige til Foden af Klitterne, idet Braadet løber op paa Land indtil $4 \mathrm{~m}$ over almindeligt Højvande«.

Ved Vang Kirke har den gamle Kystlinje løbet i Nord--Syd langs Østsiden af Vang Sø. Højlandet skraaner jævnt ned mod Søen, nogen Kystklint ses ikke, men det maa erindres, at Overfladen af Flyvesandssletten her ligger $15-17 \mathrm{~m}$ o. H. og saaledes skjuler alle Stranddannelser og lavere Kystklinter. Mellem Vang Sø og Vestenden af den nu udtørrede Sjørring Sø er den gamle Kystlinje skjult under høje Klitter og lader sig ikke følge i Enkeltheder.

Sjørring Sø, ligeledes en af Flyvesandet opdæmmet Sø, udtørredes i 1862. Dens Vandspejl maa da have ligget $14 \mathrm{~m} \mathrm{o.} \mathrm{H.} \mathrm{Sand-}$ synligvis har Søen i Stenalderhavets Tid været en lang og smal Fjord, men noget Bevis derfor haves ikke, idet muligt forekommende marine Lag er dækkede af mægtige Lag Ferskvandsdynd. Hist og her langs den tidligere Søbred findes smaa, stejle Erosionsbrinker, der dog næppe er af marin Oprindelse. Gaar man ud fra det tidligere, naturlige Afløb, fra Egebaksande Syd paa gennem Aarup Aa, maa Søens Vandspejl oprindelig have ligget $16 \mathrm{~m}$ o. H. Med denne Højde vilde Voldstedet Djernæs paa Søens Nordside netop være omflydt af Vand, og med samme Højde vilde Søen naa ind i Gravene omkring Voldstedet »Sjørring Volde« ved Søens Østende. Men forinden Søen udtørredes i 1862, maa Vandspejlet være bleven sænket til ca. 14 m ( 45 Fod) o. H. (sml. en Skitse i Trap: Danmark, II. Udg. 1878, S. 142).

Mellem Jannerup ved Sjørring Sø og Nordenden af Ovesø er Stenalderhavets Kystlinje vanskelig at paavise. Det gamle Land har været temmelig lavt, og Flyvesandet har derved haft let ved at udviske de oprindelige Former og givet Landskabet et helt andet Præg. Forskellige Forhold tyder dog paa, at det gamle Land som en lille Halvø er naaet ud mod Vest til den nuværende Vorup Sø, til Dels beskyttet af udenfor liggende, mindre Øer. En af disse er endnu bevaret nemlig Stenbjerg, Sydvest for Vorupør Kirke. Den viser sig nu som en lille, i VNV-ØSØ langstrakt Banke, der helt eller delvis bestaar af Moræneler, en Lokalmoræne af Blegekridt. Men om den virkelige Udstrækning af denne Diluvialbanke, den tidligere $\varnothing$, er det vanskeligt at dømme. Flyvesandssletten ligger nemlig paa Bakkens Sydside 17-18 m o. H., paa dens Nordside 20--22 m, og endvidere findes mod Vest høje Klitter, hvis Toppe ligger 30-35 $\mathrm{m}$ o. H., medens den diluviale Banke kun naar til $25 \mathrm{~m} \mathrm{o}$. H. Det mægtige Flyvesandsdække skjuler saaledes ikke alene den gamle 
Strandbred, der har omgivet den tidligere $\varnothing$, men maaske ogsaa store Partier af denne selv.

Nord for Stenbjerg danner den nuværende Kystlinje ud for Vorupør en ejendommelig Udbugtning; af samme Udseende som den i det foregaaende beskrevne Ørhage ved Klitmøller. Ogsaa her ved Vorupør giver de geologiske Forhold Forklaringen: Ved den indre Ende af den for faa Aar siden byggede Læmole er der ved Boring paavist Kalksten med Flintlag i en Dybde af $2^{1 / 2} \mathrm{~m}$ under Havets Niveau. At det drejer sig om en Forekomst af Blegekridt, fremgaar af Boringerne, der førtes ned gennem vekslende Lag af »blød Kalk « og » fast Kalk med Flint«, et Forhold der netop er karakteristisk for Blegekridtet i denne Del af Landet. Endvidere udgaar der (i Følge »Danske Lods«) fra Vorupør Pynten et i VNV løbende Rev af større og mindre Sten, i Reglen store, flade Fragmenter af Blegekridtets Flintlag. Mulig er denne Blegekridt-Banke med de oven paa Kalken liggende Flintblokke Rester af en tidligere $\varnothing$, der er bleven et Offer for Havets nedbrydende Kraft.

Ved Gaarden Legind ved Nordenden af Ovesø træffer man igen paa en iøjnefaldende Kystklint fra Stenalderhavet. Skrænten, der delvis bestaar af Blegekridt, kan følges dels et Stykke Syd paa langs Søen, dels lige saa langt Nord for Søen, hvor den hæver sig stejlt op over det foranliggende, flade Land. Ovesø, hvis Vandspejl nu ligger $2.8 \mathrm{~m}(9 \mathrm{Fod})$ o. H., har i Stenalderhavets Tid været en 8 $\mathrm{km}$ lang og $1 / 2-1 \mathrm{~km}$ bred Fjord. Rimeligvis har der ved Legind strakt sig en Sidearm ind mod Øst gennem de nuværende lave Enge til Nørhaa Sø, hvis Vandspejl kun ligger $3.1 \mathrm{~m}$ (10 Fod) o. H., og maaske har ogsaa den store Tørvemose Aakær, Øst for Hvidbjerg Kirke, været en Gren af Fjorden. Derimod har der ikke ført noget Sund videre mod Syd gennem Dalen omkring Hvidbjerg Aa til Ørum Sø.

Sydvest for Ovesø er det meget vanskeligt at angive Stenalderhavets Kystlinje nøjagtigt. Det gamle Land har her skraanet jæunt ud mod Vest, og senere Tiders Sandflugt har drkket og skjult de af Stenalderhavet aflejrede Havstokke. Hvidbjerg og Ørum Kirker ligger paa Istidsdannelser, og Kystlinjen maa have løbet noget Vest herfor, rimeligvis langs Østsiden af Storkjær. Flade Sø og Ørum $\mathrm{S} \varnothing$ har været en Gren af Limfjorden, der her er naaet ind til Morup Vandmølle, V for Bedsted, og sandsynligvis har Ørum og Lodbjerg Sogne været adskilte ved et smalt, nu af Flyvesand udfyldt Sund. Lodbjerg-Øens Grænser mod Nord og Vest er yderst usikre; rimeligvis har denne $\varnothing$ ved et Sund været adskilt fra en anden stor, NV for Flade Sø liggende $\varnothing$.

Grænserne for denne, NV for Flade Sø liggende, tidligere $\varnothing$ kan 
delvis bestemmes ved Hjælp af Profilerne $\mathrm{i}$ den nuværende Klint ud mod Vesterhavet. Af Kortet ses, hvorledes kun Halvdelen eller maaske mindre end Halvdelen er tilbage af den oprindelige $\varnothing$; Resten er i Tidens Løb skyllet bort af Havet. Lige saa stærk har Erosionen været lidt sydligere ved Aalum og Agger og er først i nyeste Tid hæmmet ved Bygningen af Høfder.

Hvor meget Land der er forsvundet i historisk Tid kan næppe afgøres. Nogen Vejledning har man i gamle Angivelser om det dyrkede Lands Størrelse og om de Afgifter, der betaltes; endvidere ved Beliggenheden af den gamle Agger Kirke o. s. v. Men her som saa mange andre Steder paa Jyllands Vestkyst er Beretningerne om det tabte Lands Størrelse vistnok meget overdrevne. Dog er der alene i de sidste 50--100 Aar sket store Forandringer paa denne Kyststrækning. Andresen omtaler ${ }^{1}$ ) saaledes en Lerbakke, der strækker sig fra Lodbjerg Sogn »til Agger gamle Kirkebakke, hvilket er omtrent det sydligste Punkt af denne Bakkerække, som er omtret $1 / 2 \_3 / 4 \mathrm{Mil}$ lang, kun paa et Par Hundrede Alen afbrudt ved Aalum, hvor den gaar nogle Fod under Overfladen«. Nu er Kystlinien rykket saa meget Øst paa, at Gabet ved Aalum er vokset fra et Par Hundrede Alen til ca. $1 \mathrm{~km}$ (1500 Alen), og af Aggerbjerg findes kun nogle mindre Bakkeknuder bevarede. Østerbol omtaler ${ }^{2}$ ) endnu i 1878 Aggerbjerg som en 3000 Fod (henved $1 \mathrm{~km}$ ) lang Lerbakke. Til Bedømmelse af, hvor meget der aarlig skylles bort af Kysten, før Høfderne byggedes, giver Andresen nogle Tal: fra 1822 til 1830 borttog Havet ialt 64 Alen af Agger Kirkebakke, eller gennemsnitlig $5 \mathrm{~m}$ aarlig. I Tidsrummet fra 1815 til 1839 bortskylledes 225 Alen, eller gennemsnitlig 5.6 $\mathrm{m}$ aarlig. Her som andre Steder er Tabet af Land dog ikke det samme fra Aar til Aar, men varierer stærkt. Under en enkelt Storm i 1822 bortskylledes der saaledes 24 Alen $(15 \mathrm{~m})$ af Agger Kirkebakke, der bestaar af fast Moræneler. I 1827 stod Agger gamle Kirke 27 m fra Skrænten; i 1839 styrtede den i Havet, og en ny Kirke byggedes derefter et Par Kilometer fra Kysten. Længere Nord paa har Tabet af Land været ringere. ANDRESEN angiver saaledes, at ved Sogneskellet mellem Agger og Lodbjerg Sogne $(3-4 \mathrm{~km}$ $\mathrm{N}$ for Agger Kirkebakke) er der i de 14 Aar fra 1845 til 1859 borttaget 51 Alen af Kysten, altsaa gennemsnitlig $2.3 \mathrm{~m}$ aarlig. Endnu nordligere, mellem Hvidbjerg og Stenbjerg Sogne var Bortskæringen i samme Tidsrum 35 Alen eller $1.6 \mathrm{~m}$ aarlig.

Nordvest for Flade Sø og tæt Syd for Skellet mellem Agger og

1) C. C. Andresen. 1861. Om Klitformationen og Klittens Behandling og Bestyrelse. Kjøbenhavn. S, 40.

2) A. Østerbol. 1878. Fra Agger Sogn. Geogr. Tidsskr. Bd. 2. Kjøbenhavn. 
Lodbjerg Sogne fandtes tidligere »den sorte Knop«, en stor, løs Blok af Glimmerler, indlejret i eller i alt Fald dækket af Moræneler. Andresen (1861, anf. St.) angiver dens Dimensioner i Klinten til: Længde 100 Fod $(30 \mathrm{~m})$, Højde 15 Fod $(4.7 \mathrm{~m})$ og det dækkede Lag Moræneler ligeledes til 15 Fod $(4.7 \mathrm{~m})$. Østerbol (1878, anf. St.) beskriver den sorte Knop som et 40 Fod $(12 \mathrm{~m})$ langt og 10 Fod (3 m) højt Parti af Glimmerler. Nu eksisterer den ikke mere; i 1901 iagttog Forfatteren kun en mindre, løs Flage af Glimmerler i Moræneleret, men ellers kun kvartære Lag i denne Klint. Moræneleret udgør som næunt en væsentlig Del af Klinten og for saa vidt den vigtigste Del, som det er ualmindelig rigt paa smaa og store Sten (for største Delen lokale Bjergarter, Flint, Blegekridt og Limsten; desuden de sædvanlige Gneiser, Graniter, samt Rhombeporfyr m. m.) og derved bidrager sit til Kystens Sikring. Moræneleret kan være stærkt bænket, næsten lagdelt, og har sine Steder en Mægtighed af over $10 \mathrm{~m}$. Mod Nord er Klintens Modstandskraft mod Havets Angreb ikke saa stor, idet Moræneleret her aftager i Mægtighed og samtidig underlejres af glaciofluvialt Materiale, dels Sand og Grus, dels glimmerholdigt Diluvialler, der oftest er brokket og uden Lagdeling. I Lavninger i Moræneleret kan der være aflejret fra 1 til henved $2 \mathrm{~m}$ stenfrit, sandet, senglacialt Ler, der dækkes af Tørv, som atter overlejres af Flyvesand.

Saavel ved Nordenden som ved Sydenden af Klinten findes postglaciale Ferskvandslag, Tørv, Gytje og Ler, i eller lidt over Havets Niveau, og som Regel stærkt komprimerede af de Flyvesandsmasser, der har dækket dem. Andresen (anf. St. Side 128) omtaler saadanne Tørvelag, ved Lodbjerg, Aalum og Vester Agger: „Paa de to førstnævnte Steder [ved Nordenden og ved Sydenden af den overfor beskrevne Klint] ligger den i Havstokken og ind under Klitten, .... Tørven hviler paa stenet Blaaler, er af et Par eller nogle Fods Dybde og ikke tilgængelig, undtagen naar Havet bortskyller endeel af Klitten og Overfladen af Havstokken, hvorved den tildeels blottes eller dog kun er bedækket af et Par Fod Gruus. Undertiden blottes Undergrunden, som udgør Mosens Sider, saameget, at man ved Aalum seer Egestøde med deres Rødder fra den fordums Skov, som engang har bedækket Jordbunden her og bidraget til Tørvens Dannelse, staae i deres naturlige Stilling heftede til den lerede Grund. Mosens Bund ligger paa begge Steder dybere end Havet, og Moserne ere Skovmoser. Især er det Birk, Eg og tildeels Hassel, hvoraf Tørven bestaar «. Disse Moser, der ligger i Randen af den tidligere $\varnothing$, og hvis Bund for en Del ligger under Havets Niveau, er sandsynligvis dannede forud for Stenalderhavets Tid, i alt Fald forud for Landsænkningens Maksimum, ved hvilken de dækkedes af Strandgrus. 
De i højere Niveau liggende Mosers Vækst er derimod fortsat, indtil Sandflugten ødelagde Vegetationen; dette gælder f. Eks. om den af Østerbol (anf. St.) omtalte lille Mose, der blottedes ud for Vester Agger, og i hvilken der fandtes: »et næsten fuldstændigt Skelet af en Uroxe, Takker af Raadyr, et Par slebne Øxer, Stammer af Eg og Birk samt Hasselnødder«. Det samme gælder om en af ANDREsen beskrevet Mose i Klinten ved Agger; Profilet var her (Andresens Betegnelser er bibeholdte):

$$
\begin{aligned}
& \text { 15-20 Fod }(4.7-6.3 \mathrm{~m}) \text { Flyvesand. } \\
& 1 \frac{1}{3}, \quad(0.4 \mathrm{~m}) \text { muldet Sand og sandet Muld med enkelte } \\
& 1, \quad(0.3 \mathrm{~m}) \text { Tørv dannet af Vandplanter. } \\
& 2, \quad(0.6 \mathrm{~m}) \text { Lag af Grene og Blade, nederst fortrinsvis } \\
& \text { Birk og Hassel, øverst overvejende Eg. } \\
& { }^{1 / 4}, \quad \quad(0.08 \mathrm{~m}) \text { Mostørv (Hypnum) med mange Frø af Bukke- } \\
& \text { blad (Menyanthes). } \\
& 1 / 6-1 / 4,(0.04-0.05 \mathrm{~m}) \text { Lag af Grene og noget Ler blandet med } \\
& \text { Skaller af Planorbis marginatus (Planorbis } \\
& \text { umbilicatus), der forekom i saa stor Mæng- } \\
& \text { de, at Laget paa enkelte Steder var hvidligt } \\
& \text { deraf. } \\
& \text { Nederst Blaaler. }
\end{aligned}
$$

Her er Sandflugten først begyndt, og Mosens Vækst ophørt, i den fugtige Tid, der fulgte efter Egetidens tørre (subboreale) Periode. Det anførte Moseprofil, hvis Beskrivelse bærer Præg af samme Nøjagtighed og Iagttagelsesevne som Adresens øvrige Arbejde, viser - i meget lille Maalstok - den fra norske og svenske, senere ogsaa fra danske Moser kendte Vekslen mellem fugtige og tørre Vækstperioder.

I Forbindelse med Naturforholdene i denne Egn paa Stenalderhavets Tid maa endnu nævnes en Angivelse af Østerbol (anf. St. Side 130) om Fundet af to Affaldsdynger i Nærheden af Agger. Meddelelsen er desværre meget kortfattet: »Ved Bjærgets østlige Fod findes, en halv Snes Alen Nord for Agger Skole og lige ved Vejen, en mindre Kjøkkenmødding. Hovedmassen dannes som sædvanlig af Østerskaller; desuden findes i den Strandsnegle, Hjærtemuslinger, Blaamuslinger, enkelte Knokler af Pattedyr, bl. a. af Sæl, og Flintflækker«. »Da Flade Søs Udtørring paabegyndtes og Landkanalen gravedes langs Foden af Taabel Bakker, fandtes .... ogsaa en Kjøkkenmødding, som især indeholdt en Mængde Flintflækker«. Disse Affaldsdynger, der utvivlsomt hidrører fra Stenalderen — den store Mængde Østerskaller ved Agger Skole tyder paa den ældre Stenalder - er et Vidnesbyrd om, at Nissum Bredning paa den Tid ikke har 
været en aaben Bugt fra Vesterhavet, men et helt eller delvis beskyttet Indhav.

Den Tange, hvorpaa den østlige Del af Agger ligger, og som skiller Flade Sø fra Nissum Bredning, bestaar af udprægede Limfjordshavstokke. De udgaar fra det gamle, høje Land ved Krik, V for Vestervig Kirke, og breder sig herfra som et System af smalle Strandvolde vifteformet mod Nordvest og Vest over til Agger. Materialet er Sand og Grus med indtil ægstore Sten, men hverken Stenenes Form eller Strandvoldenes smalle Rygge tyder paa, at de er aflejrede af Vesterhavet. Typen er den samme som ved Odde Sund og alle andre Steder i Nissum Bredning; intet Steds findes Vesterhavstokke, der kunde vidne om, at den vestlige Del af Limfjorden havde været en aaben Bugt fra Vesterhavet, men kun typiske Limfjordshavstokke, der paa den tydeligste Maade viser, at der i hele den postglaciale Tid maa have ligget en beskyttende Tange som Skel mellem Vesterhavet og den nuværende Nissum Bredning. Dette Forhold skal iøvrigt belyses yderligere i det følgende Afsnit.

Strandvoldene mellem Krik og Agger naar indtil $3.8 \mathrm{~m} \mathrm{o.} \mathrm{H.,} \mathrm{og}$ da Nutidsstrandvolde i Nissum Bredning næppe naar højere end til $2.3-2.5 \mathrm{~m}$, tyder det paa en Landhævning paa noget over $1 \mathrm{~m}$. Til Sammenligning kan nævnes, at Vesterhavets Nutidshavstok (fra Vinterstormene) $\mathrm{V}$ for Agger af Forf. maaltes til 3.7-3.8 m o. H. Andresen skriver (anf. St. Side 32): „Det højeste, hvortil Bølgeslaget er naaet her ved Agger i min Tid er 9 Fod over Havets daværende Vandstand, som var 4 Fod over daglig Vandstand, altsaa 13 Fod [4 m] over denne $\ll$.

Paa Stenalderhavets Tid har Vestkysten af Thy altsaa haft et fra Nutidens Kyst meget afvigende Udseende. Mod Nord og Syd fandtes stærkt fremspringende Punkter, Hanstholmen og Aggerøen. Den mellem disse Punkter liggende Kyststrækning, der laa 4-6 km indenfor Nutidens Kystlinje, var bugtet, enkelte Steder skød smalle Fjorde (nuværende Søer) sig endog dybt ind i Landet, og foran Kysten laa mindre Øer, hvoraf der endnu findes mere eller mindre tydelige Rester, f. Eks. Ørhage ved Klitmøller, Vegebjerg, Vorupør og Stenbjerg. Medens Hanstholm med sine Kridtklinter og sin store, kompakte Masse modstod Havets Angreb, gik det stærkt ud over de mindre Holme og den af Istidsdannelser bestaaende Aggerø. Ved Samvirken mellem Landhævning og Aflejring af det af Kyststrømmen transporterede Sand og Grus opbyggedes efterhaanden den $4-6 \mathrm{~km}$ brede og $35-40 \mathrm{~km}$ lange Landstrækning i Vest-Thy udenfor den gamle Kystlinje. Meget Land maa være gaaet til Grunde for at skaffe Materiale 
hertil; store Mængder af Sand og Grus har Strømmen vel ogsaa skaaret ud af Havbunden og ført ind paa Kysten. Men af disse udstrakte Havstokaflejringer ser man i Nutiden næsten intet; alt dækkes af Flyvesandet, der ligger dels som et jævnt Dække over de marine Lag, dels optræeder som mægtige Klitpartier.

Et Indtryk af, hvilke umaadelige Mængder af Flyvesand, der er føget ind over Landet, faar man ved Hjælp af Højdekurverne paa Generalstabens Kort. Selv om man ser bort fra Klittoppe, Klitrækker og det Flyvesand, der er vandret tværs over det nydannede Forland ind paa det gamle Land, kommer man dog til meget store Tal.

Fra Hanstholm til Vandet Sø og Klitmøller har det marine Forland en Bredde af $3-5 \mathrm{~km}$. Paa de vestligste $15-1800 \mathrm{~m}$ stiger Landet meget jæunt fra 0 til $16 \mathrm{~m}$; derefter findes en $2-2^{1} / 2 \mathrm{~km}$ bred, næsten horizontal Flade med en Højde af $16-16^{1 / 2} \mathrm{~m}$ o. H., og inderst, nærmest den gamle Kyst, træffer man en svag Sænkning, delvis udfyldt af de flade Klitsøer Nord for Nors Sø. Da man paa denne Strækning næppe kan vente at finde Havstokaflejringer til større Højde end $7-7^{1} / 2 \mathrm{~m}$, ligger der altsaa her - bortset fra Klitterne - et Flyvesandsdække paa indtil $8-9 \mathrm{~m}$ over de marine Lag.

Fra Klitmøller til Stenbjerg har Forlandet en gennemsnitlig Bredde af $5 \mathrm{~km}$. Fra den nuværende Kyst hæver Landet sig med regelmæssig Stigning paa de første $1 \frac{1}{2}-2 \mathrm{~km}$ til $18-19 \mathrm{~m} \mathrm{o}$. H.; derefter følger et $2 \mathrm{~km}$ bredt Plateau med en Højde af $19-21 \mathrm{~m} \mathrm{o.} \mathrm{H.,} \mathrm{og}$ Øst derfor sænker Landet sig atter ind mod den gamle Kyst og de dér liggende Søer, Vang Sø (15.7 m o. H.), Vorup Sø (17 m o. H.) og den tidligere Sjørring Sø. Vestsiden af den højeste, flade Del af Forlandet ligger i Fortsættelse af Vegebjergs Vestside og løber derfra Syd paa til Stenbjerg, parallelt med den gamle og den nuværende Kystlinje. Det er aabenbart en gammel Havstok eller Kystlinje, der endnu trods Flyvesandet giver sig til Kende i Overfladens Højdeforhold. Flyvesandsdækkets Tykkelse paa denne Strækning kan anslaas til $10-12 \mathrm{~m}$.

Fra Stenbjerg til Lodbjerg og Agger er Forlandets Bredde gennemsnitlig $5 \mathrm{~km}$; Højdeforholdene er dog ikke fuldt saa regelmæssige her som Nord paa. Den højeste Del af Forlandet Syd for Stenbjerg ligger meget tæt ved Nutidens Kyst, idet Overfladen af det jævne Land paa mindre end $1 \mathrm{~km}$ stiger til $16-18 \mathrm{~m} \mathrm{o.} \mathrm{H.;} \mathrm{dette} \mathrm{højeste} \mathrm{Parti}$ er nærmest Stenbjerg temmelig smalt, $1 / 2--1 \mathrm{~km}$. Paa de første $4 \mathrm{~km}$ Syd for Stenbjerg nærmer det sig Nutidskysten mere og mere, indtil det ud for Nordenden af Ovesø tager en mere sydlig Retning og efterhaanden med voksende Bredde svinger ind mod den gamle Kyst midt imellem Hvidbjerg og Ørum Kirker. Hældningen fra denne 
Rygs højeste Del ind mod Øst er som Regel meget ringe; kun udfor Nordenden af Ovesø er Hældningen temmelig stærk, idet Søens Vandspejl som tidligere nævnt kun ligger $2.8 \mathrm{~m}$ o. H. Følger man en Linje fra Søens Nordende mod VNV, vinkelret paa den nuværende Kystlinje, stiger Overfladen paa de første $1500 \mathrm{~m}$ fra 3 til $14 \mathrm{~m} \mathrm{o}$. H. Paa de følgende $2^{1 / 2} \mathrm{~km}$ er der en meget ringe Stigning, fra 14 til $18 \mathrm{~m}$, hvorefter Landet paa den sidste Kilometer sænker sig rask ned mod Havet. Dog er denne yderste Bræmme saa dækket med Klittoppe, at Overfladens gennemsnitlige Hældning ikke træder tydelig frem; paa flere Strækninger staar Klitterne endog med stejle Skrænter ud mod Nutidshavstokken.

Over de marine Lag mellem Hanstholm og Agger, et Areal paa mange Kvadratkilometer, ligger der saaledes et Dække af Flyvesand paa 8-10-12 Meters Tykkelse, foruden de mægtige Klitpartier, der giver hele Landskabet et eget Præg. Man staar da overfor Spørgsmaalet om, hvorfra disse uhyre Masser af Sand er komne, om de hidrører fra Vesterhavets Bund og af Strømmen er sat ind paa Kysten, og i hvilket Tidsrum dette er sket. Intet Steds kan det siges, at Stenalderhavets Kystlinje er markeret ved samtidige Klitter; overalt synes det være den nuværende Kystlinje, der er Udgangspunktet for Sandflugten og Vandreklitterne. Man kunde maaske tænke sig, at medens de store Sandmasser, der allerede under Landets Hævning førtes ind mod Kysten, blev fæstnede her som Havstokke og opbyggede det ny Land, ændredes Forholdene, da Landhævningen ophørte, og da der ved forskellige Kræfters Sammenspil var dannet en Kystlinje, der var forholdsvis konstant og tilpasset efter Forholdene. Det stadig tilførte, store Overskud af Sand blev da omsat fra Strandsand til Flyvesand og dyngedes op langs Kysten. Da Forholdene paa Landjorden i langt senere Tid ændredes, — ved Skovenes, Krattenes og Klitvegetationens Ødelæggelse - kunde Kystklitterne som Vandreklitter uhindret vælte sig ind over Landet og afstedkomme de gennem historiske Beretninger saa velkendte Ødelæggelser. Selv om der endnu i vor Tid føres en Del Sand fra Vesterhavet ind paa Kysten, og selv om Mængden af det Sand, der aarlig eller daglig vandrer langs Jyllands Vestkyst, maa angives med meget høje Tal, synes der dog at være sket en meget betydelig Nedgang i Tilførslen, en Nedgang, hvortil Aarsagen vanskelig lader sig paavise.

Af det foregaaende vil det være forstaaeligt, at der paa Strækningen mellem Hanstholm og Agger ikke er et eneste Sted, hvor man kan hente Oplysning om Landhævningens Størrelse; endvidere har Stenalderhavets Kystlinje kun kunnet angives med Sikkerhed paa Steder, hvor det gamle Land har været saa højt og staaet med en Kystskrænt, der var saa stejl, at Flyvesandet ikke har kunnet skjule 
den. Endelig er der ogsaa en Mulighed for, at der skjult under dette uhyre Flyvesandsdække og under de mægtige Klitpartier kan ligge større eller mindre Banker af Kalksten eller glaciale Aflejringer, som i Stenalderhavets Tid har været Øer udenfor den egentlige Kyst, og som har spillet en Rolle ved at beskytte denne. I denne Forbindelse maa der ogsaa henvises til det i det foregaaende beskrevne, $1-2 \mathrm{~km}$ brede og 16-20 m o. H. liggende Plateau, der som en Højderyg i nogen Afstand fra Stenalderhavets Kystlinje kan følges fra Hanstholm Syd paa til mellem Hvidbjerg og Ørum Kirker, og som slutter sig nøje til flere af de tidligere Øer. Mulig er denne Højderyg en Afspejling af gamle, høje, nu af Flyvesand dækkede Havstokke eller Revler, der er dannede paa et tidligt Tidspunkt under Landhærningen, og som saaledes kan have medvirket til at beskytte den indenfor liggende Kyststrækning mod Vesterhavets Angreb. De i Særdeleshed mod Syd svagt udviklede Kystskrænter kunde tyde herpaa.

Syd for det egentlige Thy, kun forbundet dermed ved en lav Tange, Draget, ligger Thyholm. Store Forandringer er der ikke sket her siden Landsænkningens Maksimum; den tidligere $\varnothing$ er ved Dannelsen af Draget blevet landfast med Thy; en Odde, Sunddraget, er vokset ud mod Syd og har indsnevret Oddesund til en $1 / 2 \mathrm{~km}$ bred og 20-24 m dyb Rende, og endelig er et Par smalle Fjorde, der Syd for Søndbjerg og Vest for Hvidbjerg strakte sig $2-3 \mathrm{~km}$ ind i Landet, blevet tørlagte.

Syd- og Vestsiden af Draget bestaar af et System af stenede. Strandvolde. Nutidshavstokken (Tanglinjen) ud mod Nissum Bredning ligger $2.1-2.3 \mathrm{~m} \mathrm{o}$. H., medens de gamle Strandvolde naar til $3.8-3.9$ $\mathrm{m}$ o. H. Dette vilde altsaa kun svare til en Landhævning paa ca. $1 \frac{1}{2} \mathrm{~m}$; dog er det ikke rimeligt, at Strandvoldene her ude paa Draget er dannede under Sæenkningens Maksimum, snarere er de aflejrede noget senere. Det tidligere Sund er vistnok først blevet lukket mod Syd mellem Thyholm og den lille Banke Thybjerg ude paa Draget. Mod Nord, nærmest Thy, er Strandvoldene langt yngre og saa lave, at de endnu kan overskylles ved Stormfloder, og først for nylig er den der liggende Thyholmvejle blevet udtørret. Stedet har selvfølgelig været overordentlig gunstigt for Limfjordens Dyreliv, og i de marine Lag i Thyholmvejle findes Rester af en rig og veludviklet Fauna.

Sunddraget, Sydspidsen af Thyholm, bestaar ligeledes af stenede Strandvolde. Deres Højde er $3.4-3.7 \mathrm{~m}$ o. H.; Nutidshavstokken naar til $2.1-2.3 \mathrm{~m}$ o. H. Jegind $\varnothing$, Øst for Thyholm, har i Stenalderhavets Tid varet delt i to Øer, en større nordlig og en mindre. sydlig. Det tidligere Sund mellem de to Øer er nu et lavt, næppe 
1 m o. H. liggende Engdrag. Paa Øens Sydende, Jegind Tap, findes veludviklede Strandvolde til en Højde af $3.4 \mathrm{~m}$ o. H.

Om Øen Mors siges der i æeldre Beskrivelser, at den er vokset sammen af en Mængde mindre Øer. Dette er dog i høj Grad overdrevet, selv om der flere Steder er sket betydelige Forandringer siden Stenalderen.

Nordligst er den lille, plateauformede Banke, Feggeklit, bleven landfast med Hovedøen. I Litorinatiden har Feggeklit været udsat for stærk Erosion; baade mod Øst og Vest staar Banken med stejle Sider. Mod Øst, hvor Stranden er smal og lav, angriber Havet endnu, saa at det stærkt foldede Moler ses i den lodrette Klint; mod Vest er der senere lagt Strandvolde op foran Banken, og den gamle Kystskrænt er nu græsdækket, men Erosionen har dog vedvaret saa langt ned i Tiden, at Mærkerne efter den højeste Vandstand er forsvundne eller meget utydelige. Ved Bankens Nordende findes en næsten udvisket Kystlinje $5.6 \mathrm{~m}$ o. H.; de Strandvolde, der ses ved Bankens Nord- og Sydende, naar kun til $3-3.5 \mathrm{~m}$ o. H. og er altsaa langt yngre. Landets Tilvækst omkring Feggeklit er nemlig under Landhævningen foregaaet ved Materialtransport fra Sydvest mod Nordøst, først fra Mors ud mod Feggeklit, derefter videre mod Nord, hvorved Feggesund er blevet indsnevret (Sundet har paa det smalleste Sted en Dybde af $20 \mathrm{~m}$ ). De Strandvolde, der udgaar fra Mors, er altsaa de reldste og har en Højde af $4.7 \mathrm{~m} \mathrm{o.} \mathrm{H.;} \mathrm{inde} \mathrm{i}$ en af disse Strandvolde dannet Lagune, hvor der ikke kan have været nogen synderlig Bølgebevægelse, naar det med lukkede Skaller af Cardium edule fyldte Strandsand til $3.5-3.8 \mathrm{~m}$ o. H., hvilket Tal omtrentlig maa angive Landhævningen paa dette Sted.

Fra Nordenden af Mors har en smal Fjord strakt sig ca. $4 \mathrm{~km}$ Syd paa ind i Landet forbi Hesselbjerg og Sejerslev til Vester Hundrup; den for et halvt Hundrede Aar siden udtørrede Hunsø var en Rest af denne Fjord.

En ret betydelig Landvinding er foregaaet mod Nordvest ved Skarrehage og paa Østkytsen ved Jørsby. Paa sidstnævnte Sted er der fra Nord til Syd opbygget en Strandvold, der stadig vokser videre mod Syd som en lang Tange, Buksør (Buxer) Odde, i Læ af hvilken de lave Strandenge inde i Draaby Vig er groede op i meget sen Tid.

Fra Draaby Vig har der i omtrent nordlig Retning strakt sig et Sund forbi Ullerup og Flade over til Thisted Bredning, saaledes at den nordlige Del af Mors under Litorinasæenkningens Maksimum har været en selvstændig $\varnothing$. Dette Sund er dog - kort efter at Landhævningen var begyndt - blevet lukket og omdannet til to 
Fjorde fra Nord og fra Syd, idet Sandbunden omtrent midtvejs i det tidligere Sund ligger saa højt, at det salte Vand netop, da Landsænkningen var størst, har kunnet strømme hen derover. Ser man bort fra de Sunde, der i Stenalderhavets Tid skilte Feggeklit og nogle andre Smaaholme fra Hovedøen, er Sundet ved Ullerup det eneste, der nogen Sinde har strakt sig igennem Mors; og da det utvivlsomt er blevet lukket allerede meget tidligt i Stenalderen, er der intet som helst Grundlag for de ældre Beretninger om, at Mors har bestaaet af 7 eller endnu flere Øer.

Længere mod Syd har et Par Fjorde naaet langt ind i Landet. Den største og den interessanteste er den Fjord, der fra Dragstrup Vig har strakt $\operatorname{sig} 6-7 \mathrm{~km}$ ind $\bmod \varnothing$ st forbi Eerslev. Ude ved Dragstrup Vig har Fjorden bestaaet af flere Grene, der omsluttede nogle Smaaholme; ind mod Eerslev, hvor Fjordens Bredde var meget betydelig, findes øverst $1 / 2-1 \frac{1}{2} \mathrm{~m}$ Tørv, derunder marint Ler eller Dynd af meget vekslende Mægtighed og med Skaller af Muslinger og Snegle, og under dette Lag fra Fjordtiden træffes atter Tørv, der stammer fra Fastlandstiden, eller fra Litorinatidens Begyndelse, da Landet endnu laa noget højere end i vor Tid. De marine Lag inde i den gamle Fjord er kun fulgt til en Højde af $2 \mathrm{~m}$ o. H.; i Fjordens Munding er der Syd for Dragstrup Kirke opkastet Strandvolde, hvis Rygge nu ligger indtil $3.8 \mathrm{~m}$ o. H., og desuden ses Erosionsterrasser, hvor Terrassehakket ligger indtil $4.4 \mathrm{~m} \mathrm{o.} \mathrm{H.}$

Fra Dragstrup Vig Syd paa langs Øens Vestkyst er der næsten overalt lagt Land til, ofte kun som et smalt Bælte. Nord og Syd for Næs Sund findes dog større, meget lavtliggende Arealer af nyt Land, og enkelte Steder ses Strandvolde til en Højde af $3^{1 / 2} \mathrm{~m}$ o. H. Agerø ved Sydvestkysten af Mors er vokset stærkt og er nu omtrent landfast med Mors, og Øst herfor har der strakt sig en tvedelt Fjord langt ind i Landet. De to nuværende Fjorde, Tissing Vig og Glomstrup Vig, naaede endnu for et halvt Hundrede Aar siden mod NO ind til Nøraa Gaard og mod SØ til Mydum Gaard, $1^{1} / 2 \mathrm{~km}$ Vest for Øster Assels; senere er de ved Kunst blevne udtørrede. Under Landsænkningens Maksimum har Fjorden naaet endnu længere Øst paa, ind til Øster Assels By; herfra fører et smalt Engdrag videre mod Øst over det flade, lave Land til den Fjord, der i Litorinatiden naaede fra Øens Østkyst her ind imod. Mellem de inderste Dele af de to Fjorde har der kun været en Afstand af $1^{1 / 2} \mathrm{~km}$, men der er dog ingen Sandsynlighed for, at de har staaet i Forbindelse med hinanden, da den faste, glaciale Bund i Vandskellet ligger mere end 3 m o. H., og da Landhævningen i den sydlige Del af Mors næppe tør antages at have oversteget $2^{1 / 2} \mathrm{~m}$.

Ved Nykøbing og ved Legind, $4 \mathrm{~km}$ Syd derfor, fandtes i 
Litorinatiden et Par Fjorde, der naaede ret langt ind i Landet. Den nordligste af Fjordene havde sin Munding netop, hvor Nykøbing nu ligger; Byen er for største Delen bygget paa den flade Strandvold eller Sandrevle, der under Landhævningen dannedes tværs over Fjordens Munding, og som forbandt Højlandet ved Dueholm Kloster med Banken Nordøst for Byen. Fra denne Banke, der i Litorinatiden var en $\varnothing$, idet Fjorden ogsaa havde et smalt Udløb gennem Lavningen mod Nord, er der senere vokset en Odde, Ørodde, ud mod Syd, hvorved opstod den godt beskyttede Vig, ved hvilken Nykøbing anlagdes. Strandvoldene naar ved Plantagen Syd for Byen til en Højde af $3^{1 / 2-4} \mathrm{~m} \mathrm{o.} \mathrm{H}$.

\section{Fra Agger til Løgstør. \\ (Sydsiden af Limfjorden).}

Under Omtalen af Kyststrækningen ved Agger næuntes det (Side 51), hvor stærkt Havet i den første Halvdel af det 19de Aarhundrede havde angrebet Landet og skyllet bort deraf. At ogsaa den lave Tange, der fra Agger strækker sig Syd paa forbi Thyborøn og Harboøre til Bovbjerg, har lidt meget ved Vesterhavets Angreb, fremgaar dels af de historiske Beretninger og de æeldre Kort, dels direkte af de geologiske Forhold. Ved Agger og Thyborøn kaster Havet ved hver Storm Mængder af store og smaa Lerflager op paa Strandbredden. Det er ikke, som man skulde tro, Moræneler, men fedt, blødt, stenfrit, marint Ler, fyldt med Blade af Bændeltang og med Skaller af Ostrea, Tapes. Cardium, Scrobicularia, Litorina, Trochus o. s. v.; endvidere maa det bemærkes, at Skallerne ikke er af den tykke, svære Vesterhavstype, men af Former, der nøje svarer til Individernes Udvikling inde i Nissum Bredning i Nutiden.

Medens man Nord for Agger, Vest for Flade Sø, støder paa fast Moræneler ude i Stranden, - Høfderne funderes til Dels deri -, finder man i Havet Sydvest for Agger denne gamle Fjordaflejring. Den omtales iøvrigt allerede af Andresen (1861, anf. St. Side 36) som »en Art blaa Mergel«. Han angiver, at dette Lerlag findes under hele Agger-Tangen Syd paa til Langer, NV for Harboøre; ved Røn, 6 km S for Thyborøn Kanal, er Laget saaledes ${ }^{1 / 2} \mathrm{~m}$ mægtigt, hviler paa Sand og dækkes af $1 / 2 \mathrm{~m}$ Sand. Det benyttes her til at kline med og til soltørrede, ubrændte Mursten. For nylig er dette marine Ler fundet paa Sydsiden af Thyborøn Kanal; ved en Boring, som Vandbygningsvæsenet har ladet udføre umiddelbart ved den nyanlagte Havn, og hvor Jordoverfladen ligger $1 \mathrm{~m} \mathrm{o.} \mathrm{H.,} \mathrm{fandtes}$ 
$6 \mathrm{~m}$ rent Strandsand.

29 ,, blaat Saltvandsklæg med en Mængde Skaller.

4 , fint Sand med Skaller, og derunder Moræneler.

Laget har altsaa her en usædvanlig stor Mægtighed, der, selv om den for en Del maatte skyldes lokale Forhold, dog vidner om, at Aflejringen af den marine Klæg ikke kan være foregaaet i Løbet af en kortvarig Periode, men maa have strakt sig over et langt Tidsrum. Dette Ler, der indeholder en Fauna svarende til Faunaen i Nissum Bredning i Nutiden, er altsaa ikke alene et Vidnesbyrd om Aggertangens Forskydning indad mod Øst, men tyder ogsaa paa, at den vestlige Del af Limfjorden gennem lange Tider maa have været beskyttet mod Vesterhavet rimeligvis ved en lignende Sandtange som i Nutiden.

Kystlinjens Tilbagerykning har i det 19de Aarhundrede været stærkest paa den Del af Tangen, hvor Vesterhavet har brudt igennem; siden 1791 (Videnskabernes Selskabs Kort) har Tilbagerykningen udfor Thyborøn Kanal endog varet mellem 1 og $2 \mathrm{~km}$. De i de sidste 100 Aar bestaaende Forhold, hvor der findes en bred, dyb Kanal tværs igennem Tangen, maa dog fra et geologisk Synspunkt betragtes som usædvanlige og vil i Tidens Løb kun kunne opretholdes ved Kunst. Det naturligste for Kyststrækningen fra Agger til Bovbjerg er, at disse to faste Punkter forbindes ved en ubrudt Tange, hvis Vestside danner en retlinjet Kystlinje i Fortsættelse af Kysten Nord og Syd derfor. Saaledes har det utvivlsomt ogsaa været Tilfældet forhen - med korte Afbrydelser - helt tilbage til Stenalderhavets Tid, og maaske tidligere. Den vestligste Del af Limfjorden har aldrig været en aaben Bugt ind fra Vesterhavet; det bløde, under rolige Forhold aflejrede, marine Ler, der nu ligger under Agger-Tangen tyder derpaa, og de hævede Havstokke, saavel langs Sydkysten af Thy og Vestkysten af Thyholm indtil Oddesund, som mod Syd paa Kyststrækningen fra Harboøre over Lemvig til Oddesund, er alle udprægede Limfjords-Havstokke. Ikke paa et eneste Sted i Nissum Bredning kan der paavises nogen Stranddannelse af Vesterhavstypen, og i de hævede Skallag findes en Fauna, der (i Følge Meddelelse fra V. Nordmann) ligeledes er en udpræget Limfjordsfauna. Den vestligste Del af Limfjorden maa saaledes lige siden Stenalderen have været skilt fra Vesterhavet ved en Landtange, men af og til har Havet brudt Hul i Tangen, en smal Kanal har holdt sig i nogen Tid, men derefter vil Havet atter, naar det faar Lov til at arbejde uforstyrret, lukke den og atter opbygge den jævne, ubrudte Kystlinje.

Om de geografiske Forhold ved Agger-Tangen vides der meget 
lidt fra den tidlige historiske Tid. En enkelt Oplysning haves dog, der belyser Forholdene i det 11te Aarhundrede, idet Snorre SturLusøn beretter, hvorledes Harald HaArderaAde under et af sine talrige Vikingetog til Danmark var løbet ind i Limfjorden og her blev spærret inde af Svend Estridsøn, der med en stor Flaade lagde sig ved Fjordmundingen ved Hals. HaraLD reddede sig ved at styre sine Skibe længere ind i Fjorden og om Natten trække dem over set smalt Ejd vester til Havs", hvorefter han styrede Nord paa langs Jyllands Kyst og hjem til Norge. Denne korte Beretning viser, at Limfjorden paa dette Tidspunkt har været en lukket Fjord, idet $\mathrm{HA}_{\mathrm{A}}$ RALD HaARDERaAde kun kunde undslippe ved at trække sine Skibe over en Landtange mod Vest. Utvivlsomt har Agger-Tangen eksisteret den Gang, og der kan ikke have været noget Sejlløb igennem den. Den i 1868-76 stedfundne Diskussion mellem Historikerne, saavel danske som norske, om den rette Forstaaelse af Snorre Sturlusøns Beretning skal ikke omtales her; kun maa der fra et geologisk og geografisk Synspunkt tages Afstand fra den, særlig fra norsk Side, hævdede Anskuelse, at Stedet, hvor Harald trak sine Skibe over Land, maatte være ved Bolbjerg. Ikke alene har Strandvoldene her en betydelig Højde (indtil $9 \mathrm{~m}$ o. H., sml. Side 40) og har dannet et meget ujævnt og vanskeligt passabelt Terrain, men de breder sig ogsaa over meget store Arealer. Ganske vist lader det sig ikke i Enkeltheder paavise, hvor bred denne Landtange, Forbindelsen mellem Vendsyssel og Thy, har været i det 11te Aarhundrede, før: Flyvesandet under den store Sandflugt drekkede de marine Lag; men Afstanden fra Hav til Hav har i alt Fald været saa betydelig, at det vilde være uoverkommeligt, selv for norske Vikinger, paa én Nat at trække Langskibe over denne Landstrækning.

Forholdene ved Agger-Tangen har mulig ændret sig allerede i Slutningen af samme Aarhundrede. Det falder i alt Fald vanskeligt at forstaa, at KNuD den hellige samlede den til det paatænkte Tog til England bestemte, store danske Flaade, 1000 Skibe, i den indre eller vestlige Del af Limfjorden, saafremt der ikke paa det Tidspunkt havde været uhindret Sejlads Vester ud af Fjorden.

Gennembrud vil fremkomme i Perioder, hvor Tangen ved Kystens langsomme Tilbagerykning er bleven smal og har mistet sin Modstandskraft. Der kendes fra de senere Aarhundreder adskillige saadanne Gennembrud, saaledes fra 1566, 1572, 1586 og 1685. I 1623 eller 1624 brød Havet en bred Aabning i Tangen ved Rønland, men Kanalen lukkedes dog snart. Jens Sørensens Kort fra 1694-95 viser en 2-300 $\mathrm{m}$ bred Landtange med en fuldstændig retlinjet Vestkyst; flere Smaabyer laa ude paa Tangen, og Vester Agger laa over $300 \mathrm{~m}$ fra Stranden. Ad denne Vej gik de svenske Tropper i 1657 
op i Thy, efter at de havde slaaet det danske Landeværn, 1500 Bønder, der havde taget Opstilling tværs over Tangen noget Syd for Agger. Paa Videnskabernes Selskabs Kort fra 1791 er Tangen langt smallere, men endnu den almindelige Færdselsvej fra Thy Syd paa, i Srerdeleshed for Driften med Stude, der skulde til Holsten. Vester Agger laa da tæu ved Stranden. Mod Vest var Tangen beskyttet ved en Række Klitter, og paa dens Østside var der endnu Rester af de frugtbare, marsklignende Fjordenge. Sidst i Aarhundredet led Tangen meget, den var paa sine Steder kun »et Bøsseskud « bred; Havet gik jævnlig over den ved Storm, og Fiskerne kunde trække deres Baade fra Fjorden til Havet og omvendt. Under en Storm i Februar 1825 led Tangen meget, og Havet brød igennem den ved Langerhuse NV for Harboøre; denne Kanal lukkedes dog snart efter, men Havet kunde stadig ved Storm gaa over den opkastede Revle. I November 1825 brød Havet igennem Syd for Agger og dannede en bred Kanal. Agger gamle Kirke laa da lige ved Kystbrinken, og Dele af Kirkegaarden styrtede i Havet; efter Gennembrudet bøjedes Tangen indad, baade Nord og Syd fra, ind mod Agger Kanalen, der udvidedes baade i Dybde og Bredde. I 1839 styrtede de sidste Rester af Agger Kirke i Havet, hele Tangen overskylledes, alle Klitterne skylledes bort, og gennem mange Render strømmede Havvandet ved hvert Højvande ind i Fjorden. Indenfor Agger Kanalen aflejrede den indadgaaende Strøm store Mængder af Sand, og efterhaanden voksede denne Fjordgrund saa stærkt, at den hæmmede Strømmen i Kanalen, hvorefter en Stormflod i 1863 brød en ny Rende gennem Tangen noget Syd for Agger Kanalen. Denne Rende, Thyborøn Kanal, tiltog efterhaanden i Dybde og Bredde, samtidig med at den gamle Agger Kanal sandede til og til sidst, i 1875, lukkedes. Indenfor Thyborøn Kanal indtraadte nu de samme Forhold som tidligere ved Agger Kanal, og som i nyeste Tid er kendt fra lignende Render, f. Eks. Hvide Sande ved Ringkøbing Fjord, nemlig at den indadgaaende Strøm opbyggede en stor Sandbanke i Fjorden indenfor Kanalen og derved arbejdede hen til Kanalens Tilsanding og Lukning. Blandt andet af Hensyn til Saltvandsfiskeriet i Limfjorden var det imidlertid ønskeligt at bevare Thyborøn Kanal, og en Rende blev derfor uddybet gennem Fjordgrunden, et Uddybningsarbejde, der stadig maa holdes i Gang, samtidig med at man ved Bygning af Høfder søger at fæstne Kanalens Sider og Tangens ydre, vestlige Kystlinje; men kun ved store Ofre er det muligt at holde den nuværende Tilstand vedlige og bryde med den naturlige Udvikling.

Efter at Agger Kanal og senere Thyborøn Kanal var dannede, foregik der en Bøjning indad i Limfjorden af Tangens to Grene. Andresen udstak i 1840 en Linje fra Agger til Agger Kanal og maalte 
i de følgende 17 Aar Afstanden fra denne Linje ud til Havet. I detfe Tidsrum bortskylledes gennemsnitlig $9.4 \mathrm{~m}$ aarlig, og lige saa meget bortskylledes af Tangen Syd for Kanalen. I Løbet af de 11 Aar fra Thyborøn Kanalens Dannelse til 1874 udførte Overklitfoged BREINHOLT en Række Maalinger paa den sydlige Del af Tangen. Kystens gennemsnitlige Tilbagerykning paa følgende Strækninger, der hver har en Længde af ca. $10 \mathrm{~km}$, fandtes at være: fra Thyborøn til hen imod Harboøre 11.3 m aarlig; fra Harboøre til Sydenden af Ferring Sø $5 \mathrm{~m}$ aarlig; fra Sydenden af Ferring Sø til noget Syd for Fjaltring Kirke (Bovbjerg Partiet) $4.7 \mathrm{~m}$ aarlig, og fra. Fjaltring til Thorsminde $3.1 \mathrm{~m}$ aarlig. Det ses altsaa, hvorledes Kystlinjens tilbagegaaende Bevægelse var stærkest ved Stedet for Gennembrudet og herfra forplantede sig med aftagende Styrke ud langs Kysten. Efter at det ved Bygning af Høfder er lykkedes at stanse denne Tilbagerykning ude paa Tangen og befæste Udløbet for Thyborøn Kanal, vil Landets Bortskylning dog endnu i en Aarrække - saafremt der ikke foretages tilstrækkelige Sikringsforanstaltninger — være følelig i længere Afstand fra Kanalen, dels Nord for Agger, dels ved Bovbjerg, indtil der er naaet en naturlig Ligevægttilstand og et saa jæunt Forløb af Kystlinjen som muligt.

Af det her anførte vil det ses, at de Beregninger, som enkelte Forfattere har foretaget over, hvor meget Land der er skyllet bort af Jyllands Vestkyst i de sidste 400, 1000 eller 2000 Aar, savner ethvert Grundlag. De Maalinger, der foreligger, stammer alle fra en kritisk Periode, kort efter Aggertangens Gennembrydning i dette Aarhundrede, hvor Tabet af Land selvfølgelig var eksceptionelt stort. Er der Tale om flere Hundrede eller Tusinde Aar, da vil et saadant Tidsrum omfatte saavel lange, rolige Perioder med en Kystform, der er i Ligevægt, og hvor Landtabet er ringe, som kortvarige Perioder med Gennembrud og stødvis, stærk Tilbagerykning af Kystlinjen.

Tangens sydligste Parti omkring Harboøre er, fraregnet Klitterne, et meget lavt og fladt Land, hvis Overflade kun ligger $1-2 \mathrm{~m} \mathrm{o}$. H. Enkelte Steder, f. Eks. SV for Harboøre Kirke, kan der findes Strandgrus; det er dog ikke Vesterhavs Havstokke, men Gruset er af samme Type som Strandgruset i Limfjordens Bredninger. Det samme gælder de Stranddannelser, der ses paa enkelte Steder Sydøst derfor langs Randen af Højlandet, og som naar til en Højde af $2^{1 / 2}-3^{1 / 2}$ $\mathrm{m}$ o. H. Højlandets Rand danner fra Ferring Sø mod NNØ forbi Engbjerg Kirke en tydelig og paa sine Steder stejl Kystskræent; ved Engbjerg Kirke har den endog en Højde af $25 \mathrm{~m}$. Den vidner om marin Erosion, men dog ikke stærkere, end hvad der kan findes talrige Steder i Limfjordens Bredninger. At anse denne Bakkerand for en tidligere Vesterhavskyst, er utvivlsomt fejlagtigt; intet Steds i Mun- 
dingen af Dalene findes Strandsten af Vesterhavstypen, og paa lange Strækninger, baade mod Nordøst ved Hygum Kirke og mod Syd ved Ferring Sø, skraaner det høje Land jævnt ned mod Lavlandet. Langt større Lighed er der mellem denne Skrænt og Skrænten ved Nymindegab, hvor det tidligere Udløb fra Ringkøbing Fjord har eroderet stærkt i Rendens sydlige (og østlige) Bred som Følge af Materialvandringen langs Kysten og den deraf følgende Forskydning af Udlobet i sydlig Retning. At lignende Forhold under en eller flere Perioder har gjort sig gældende ved Harboøre, er højst sandsynligt. Den store Engstrækning, der skiller Harboøre Banken fra det høje Land, ligger kun $1 / 22^{2 / 3} \mathrm{~m}$ o. H., og store Dele deraf er endnu dækkede af Vand (Hygum Nor, Noret, Mellemvese, Søndervese og Ferring Sø); den lave Tange, der skiller Ferring Sø fra Havet og beskytter den nævnte Engstrækning mod Oversvømmelse, har kun en Bredde af 2--300 $\mathrm{m} \mathrm{og}$ er et meget svagt Punkt, der endog i nyeste Tid flere Gange (i 1839, 1868 og 1874) er bleven gennembrudt af Havet. Alt tyder paa, at dette lave Engdrag og Rækken af Søer er Rester af en tidligere Kanal, et ældre Udløb fra Limfjorden til Vesterhavet, og at det, i alt Fald for en Del, er den stærke Strøm i denne Kanal, der ved sin Erosion har frembragt den stejle Bakkeskrænt mellem Engbjerg Kirke og Ferring Sø.

Følger man Bakkeskrænten fra Engbjerg Kirke videre mod Nordøst og Øst, bliver den utydelig og viser sig som en udpræget Fjordkyst, der aldrig har været udsat for Vesterhavets Angreb. Vest for Lemvig har i Stenalderhavets Tid en smal Fjord strakt sig Syd paa mellem Bakkerne indtil SV for Tørring Kirke, og NNV for Lemvig er ret store Arealer blevne tørlagte omkring Vestersø og Gjellersø. Den i disse hævede Lag fundne marine Fauna er, efter Meddelelse fra V. Nordmann, en typisk Limfjordsfauna, saaledes som nu kendes fra Nissum Bredning eller maaske endog visende hen til noget mindre Saltholdighed i Vandet end i Nutiden.

Fra Lemvig til Oddesund er der ikke foregaaet større Forandringer i Kystlinjens Beliggenhed. Hen imod Oddesund er en Fjord, der har strakt sig ind i Landet mod Sydøst, bleven tørlagt, og i dens Munding er der mellem Aamølle og Rimmerkro opkastet smaastenede Strandvolde, der naar til $3.5 \mathrm{~m} \mathrm{o}$. H. Ved Oddesund findes paa Tangens Vestside græsbevoksede Strandvolde, hvis Krone ligger 3.5-3.8 $\mathrm{m}$ o. H.; udenfor disse ses en nøgen Strandvold, der naar til $2.5 \mathrm{~m}$ og uden for den atter en nøgen Strandvold $1.6 \mathrm{~m} \mathrm{o}$. H.

Øst for Oddesund, hvor der er Læ for Vestenvinden, er Strandvoldene lave og Strandstenene ufuldstændigt rullede. Ved Struer naar Strandvoldene saaledes kun til $2.5 \mathrm{~m}$ o. H., men Nutidshavstokken har her ganske vist ogsaa kun en Højde af $1.2 \mathrm{~m}$. Paa Venø, 
der i Litorinatiden bestod af en Hovedø og nogle mindre Holme Syd derfor, er Tilvæksten af Land forholdsvis stor, men Strandvoldene naar sjældent til større Højde end $3.0 \mathrm{~m}$ o. H.

Vestsiden af Salling har i Litorinatiden været langt mere indskaaret og uregelmæssig end nu. Længst mod Syd ved Vinderup Station er en større Fjord og nogle Sunde blevet tørlagte ved Landhævningen. Kystlinjen inderst $\mathrm{i}$ Venø Bugt har derved faaet en afrundet Form, og en større $\varnothing$ samt nogle Smaaholme NV for Vinderup er blevne landfaste. Paa Vestsiden af den tidligere $\varnothing$ ved Landting findes hævede Havstokke indtil $3.4 \mathrm{~m} \mathrm{o}$. H. I Engene, den tidligere Fjordbund, ses tæt under Overfladen de hævede, marine Lag med en rig Fjordfauna.

Sønderlem Vig, Øst for Venø, har i Stenalderhavets Tid haft langt større Udstrækning end nu og har været fuldstændig aaben ud mod Vest mod Limfjorden. Ved Fjordmundingens Sydside findes Strandvolde, der naar indtil $3.5 \mathrm{~m}$ o. H., og ved Hostrup Teglværk, umiddelbart Nord for Fjordmundingen, afspærres en mindre Lavning af en lang, smal, indtil $3.7 \mathrm{~m}$ høj Strandvold, der er vokset ud fra Nordvest mod Sydøst. Nutidsstrandvolden har en Højde af $1.6 \mathrm{~m}$.

Paa de geologiske Kort over Danmarks Overfladedannelser, selv paa de nyeste Kort, angives det, at der har strakt sig et bredt Sund fra Sønderlem Vig Øst paa til Skive, saaledes at Salling skal have været en $\varnothing$, adskilt fra det øvrige Jylland. Dette er urigtigt; et saadant Sund har aldrig eksisteret, og Salling har ikke paa noget Tidspunkt efter Istiden været en $\varnothing$. I Stenalderhavets Tid havde Sønderlem Vig som nævnt langt større Udstrækning end i Nutiden, og Fjorden naaede temmelig langt mod Øst ind $\mathrm{i}$ Landet. De marine Lag kan følges Øst paa til et kort Stykke Ø for Landevejen ved Kjærgaardsholm; saa langt har Fjorden naaet. Øst herfor træffes paa en Strækning af $6-7 \mathrm{~km}$ intet som helst marint Alluvium, men udelukkende glaciale Lag, der enten naar direkte til Overfladen eller dækkes af lidt Tørv eller Engjord. At det omtalte Sund aldrig har eksisteret, ses tydeligst ved at følge Vejen fra Hvidbjerg Syd paa, tværs over Lavningen; her ligger Istidslagene næsten overalt udækkede lige op til Lyngskjolden, og kun paa det laveste Sted, der ligger ikke mindre end $7 \mathrm{~m} \mathrm{o.} \mathrm{H.,} \mathrm{dækkes} \mathrm{de} \mathrm{af} 0.6 \mathrm{~m}$ Tørv. Først tæet ved Skive træffes atter marine Lag nede i Aadalen.

Den mod Vest fremspringende Halvø ved Kaas er under Landhævningen vokset betydeligt; Kaas Sø er bleven afspærret fra Havet, og stenede Strandvolde, indtil $3.7 \mathrm{~m} \mathrm{o.} \mathrm{H.,} \mathrm{er} \mathrm{aflejrede} \mathrm{langs} \mathrm{Vest-}$ og Nordvestkysten. Noget længere mod Nordøst, ved Kysten mellem Kaas og Spøttrup, ses høje, smalle, lyngbevoksede Strandvolde, be- 
staaende af ægstore Sten og med en Højde af $4-4.2 \mathrm{~m}$ o. H. Nutidshavstokken (Tanglinjen) maaltes her til $1.9 \mathrm{~m}$ o. H. Nu skærer Fjorden atter bort af disse Strandvolde, der paa flere Steder staar med stejle Brinker ud mod Stranden. Endnu lidt nordligere har Strandvolde med en Højde af $3.5 \mathrm{~m}$ lukket for Spøttrup Sø, der tidligere har været en Fjord. Ogsaa den Nord for Spøttrup liggende Mollerup Sø har været en Fjord, der i Stenalderhavets Tid strakte sig langt ind i Landet, indtil $5 \mathrm{~km}$ fra den nuværende Kystlinje. $\mathrm{Nu}$ er Søen skilt fra Limfjorden ved brede, lavtliggende Strandenge.

Harre Vig har i Litorinatiden haft omtrent samme Udseende som nu; kun har de mod Syd og Nord udgaaende, smalle Vige, Hjerk Nor og Harre Nor, strakt sig noget længere ind i Landet. Inderst inde i Harre Vig, hvor Nutidshavstokken (Tanglinjen) kun naar til $1^{1 / 4} \mathrm{~m}$ o. H., og hvor der ogsaa i Litorinatiden maa have været et meget svagt Bølgeslag, findes Strandvolde indtil $4 \mathrm{~m} \mathrm{o}$. H.; enkelte Steder kan Strandgruset følges til $4.2 \mathrm{~m}$ o. H. Landhævningen maa paa dette Sted være i alt Fald $2.5 \mathrm{~m}$, snarere lidt mere. En i Vile Sogn paa Nordsiden af Harre Vig liggende Affaldsdynge fra den ældre Stenalder er ejendommelig ved sit store Indhold af Muslingen Tapes decussatus.

Nordsiden af Salling har i Stenalderhavets Tid været stærkt indskaaret. Den nu udtørrede Grønnerup Sø med omliggende Enge har været en stor Fjord, der fra Fur Sund strakte sig mod Sydvest til Jernbanelinjen fra Glyngøre, og som desuden stod i Forbindelse med en anden Fjord, der langs Hinnerup Aa naaede ind til Aasted og Østergaard. Fra den gamle Kyst ved Aasted kendes en Affaldsdynge fra den ældre Stenalder. Ogsaa østligere, langs Sydsiden af Fur Sund hen imod Selde er der ved Tilsanding og ved Landets Hævning vokset nyt Land frem. Strandvolde findes paa mange Steder og kan optræde som brede Bælter af Grusvolde med trinvis aftagende Højde. Inde i Salling Sund findes tæa Syd for Glyngøre Station Strandgrus som en Terrasse op mod Bakkesiden til en Højde af $4 \mathrm{~m} \mathrm{o.} \mathrm{H.} \mathrm{Længere} \mathrm{mod} \mathrm{Nordøst,} \mathrm{ud} \bmod$ den aabne Bredning, ses Nord for Grønnerup et stort System af stenede Strandvolde, der, udgaaende fra den tidligere Halvø, hvorpaa Grønnerup By nu ligger, strækker sig mod NØ og derefter bøjer mod SØ langs Fur Sund. Strandgruset naar mod Sydvest til en Højde af $4.7 \mathrm{~m} \mathrm{o.} \mathrm{H.}$ Inde i Fur Sund findes ligeledes en Del Strandvolde, bedst udviklede Nord og Vest for Selde, hvor de naar til 4.0-4.3 $\mathrm{m} \mathrm{o.} \mathrm{H.}$

Paa Øen Fur er Landet vokset stærkest mod Øst, hvor en mindre $\varnothing$ er bleven landfast med Hovedøen; den nuværende Færkør Hede bestaar, hvad ogsaa Navnet $(\varnothing \mathrm{r}=$ Grus) viser, for største Delen af Strandgrus, der dog paa enkelte Strækninger er skjult under Flyve- 
sand. De ældste Strandvolde har Retning N-S langs Østkysten af de to tidligere Øer og løber helt ud til Nordsiden af Fur, hvor de afskæres vinkelret af den nuværende Kystlinje. Dette i Forbindelse med de stejle, til Dels nøgne Klinter paa Nordsiden af Fur viser, at der her er foregaaet og endnu foregaar en stærk Bortskæring af Landet. De ældste Strandvolde i Færkør Hede naar indtil $4.4 \mathrm{~m} \mathrm{o}$. H. Ude ved Øens Vestende er det tidligere Sund, Faskjær, blevet lukket baade mod Nord og mod Syd ved 4.0-4.4 $\mathrm{m}$ høje Strandvolde. Ogsaa paa Øens Sydvestside, hvor der næppe er sket store Forandringer siden Litorinatiden, findes Strandgrus til $4.4 \mathrm{~m} \mathrm{o}$. H. Om alle de fra Fur nævnte Strandvolde gælder, at der forud for deres Aflejring er foregaaet en stærk Kysterosion, og at derfor næppe nogen af dem kan antages at hidrøre fra Landsænkningens Maksimum.

Østsiden af Salling synes $\mathrm{i}$ det store og hele at have bevaret sin Kystform uforandret lige fra Stenalderhavets Tid indtil Nutiden; dog er der paa nogle Strækninger skaaret Land bort, hvor meget kan ikke siges, medens der paa andre Steder er tørlagt Smaavige, eller der er vokset lave Strandenge op udenfor de gamle Klinter.

Nord for Hvalpsund findes hævede Strandvolde paa flere Steder, f. Eks. ved Nørre Tise, hvor der indenfor en $2.5 \mathrm{~m}$ høj Strandvold findes ældre Havstokke, der naar til 4.4-4.7 m o. H. Ved Sundgaard, ved Hvalpsunds snævreste Del, findes Strandvolde indtil $4.7 \mathrm{~m}$ o. H., og umiddelbart ved og ovenfor denne Grænse ligger en righoldig Affaldsdynge fra den ældre Stenalder. Syd for Hvalpsund, hvor Farvandet er mere lukket, er Strandvoldene svagere udviklede.

Skive Fjord, der nu kun naar Syd paa omtrent til Skive, har tidligere været stærkt forgrenet og har sendt smalle Fjorde ind mod Sydvest og Syd. Mod Sydvest har en Fjord naaet temmelig langt ind gennem Skive Aa Dalen. Marine Lag, dækkede af Ferskvandssand og Ferskvandsdynd, er ved Boring fulgte Syd paa omtrent til Fly. Mod Vest har denne smalle Fjord vistnok sendt en Arm ind gennem den nuværende Flyndersø. Vandspejlet i denne, paa Grund af sine ejendommelige Kystformer og Omgivelser oftere omtalte Sø, ligger nu $2.8 \mathrm{~m}$ o. H., men er kunstig opstæmmet ved en Dæmning ved Søens nordlige Ende. Engen umiddelbart Øst herfor ligger 2.2-2.5 m o. H., og trækkes herfra Mægtigheden af det øverste Dække af senere aflejret Ferskvandssand og Dynd, naar man ned under det Niveau, til hvilket Fjordens Vandspejl har naaet i Stenalderhavets Tid. Marine Aflejringer eller Dyrerester er dog hidtil ikke fundne inde i Flyndersø, til Dels paa Grund af Søens nuværende, ved Kunst frembragte, høje Vandstand, men vistnok hovedsagelig fordi det salte Vand kun i meget ringe Grad kunde trænge ind over den Tærskel, der adskilte den store, ret dybe Sø fra den egentlige Fjord. 
Skive ligger som bekendt nu henved $1 \mathrm{~km}$ fra Fjorden, og dens Havn er anlagt Øst for Byen ude ved Krabbesholm. Her, ved Mundingen af den tidligere Skive Fjord, fandtes den Affaldsdynge fra den ældre Stenalder, hvor igennem man for første Gang (i 1837) fik Oplysning om disse ejendommelige Kulturlag, hvis virkelige Natur og Dannelsesmaade dog først senere blev erkendt.

Øst for Skive har en anden betydelig Fjord strakt sig Syd paa ind $\mathrm{i}$ den store Lavning mellem Dommerby og Kobberup. Fjordens Udløb har været meget smalt, og da det ved Landhævningen lukkedes, omdannedes den store Bredning indenfor til en Ferskvandssø, den i 1869-72 udtørrede Tastum Sø. Til Trods for det smalle Udløb har Molluskfaunaen inde i den indre Fjord været meget rig og efterladt store Mængder af Skaller.

Udfor Mundingen af den sidst nævnte, tidligere Fjord er Landet vokset stærkt, idet tidligere Sunde og Bugter er blevet tørlagte ved Landhævningen, hvorefter den gamle Fjordbund er blevet dækket af Tørvemoser. Herved er flere store Øer Sydvest og Nordvest for Højslev og ved Lundø blevet landfaste. De gamle Sunde ses endnu i Terrainet, og de talrige Skaller af marine Muslinger nede i Engene vidner direkte om Fjordens større Udbredelse i Stenalderhavets Tid.

Af Stranddannelser kan nævnes Strandvoldene NV for Højslev, der naar til $3.4 \mathrm{~m}$ o. H., Nord for Lundø, hvor Højden er $4.4 \mathrm{~m}$, Øst for Lundø $3.4 \mathrm{~m}$, og en stor, bueformet Strandvold ved Baadsgaard, SØ for Lundø, der naar til $3.4 \mathrm{~m}$ o. H. Højderne er saaledes ikke betydelige og noget varierende, idet de bl. a. er afhængige af Beliggenheden inde i dette snævre Farvand.

I Nutiden staar Hjarbæk Fjord kun i Forbindelse med den øvrige Limfjord ved det smalle, men indtil $10 \mathrm{~m}$ dybe Virksund. I Stenalderhavets Tid var Forbindelsen friere, Virksund var bredere, og desuden førte et Sund gennem den Lavning, der nu optages af Ørslevkloster Sø og et Par mindre Søer. Dette sidste Sund havde dog næppe nogen større Betydning i hydrografisk Henseende, idet Vanddybden vistnok har været ringe, i alt Fald paa det Sted, hvor Landevejen nu gaar over Lavningen; dog er det ikke muligt at afgøre, hvor meget der her er oprindeligt, og hvor meget Fyld der senere er bragt ud for at føre Vejen over Engen. Fra Virksund kendes en Affaldsdynge fra den ældre Stenalder. Paa Sundet Vestside findes Strandvolde, der har en Højde af $3.5 \mathrm{~m} \mathrm{o.} \mathrm{H.} \mathrm{og} \mathrm{som} \mathrm{er} \mathrm{voksede}$ ud fra Nordvest mod Sydøst.

Læengere Syd paa har smalle Fjordarme strakt sig ind i Landet, dels ved Ørum langs Jordbro Aa, dels langs Fiskbæk Aa. Ved Jordbro Aa findes der Øst for Ørum Kirke, til Trods for den velbeskyttede Beliggenhed, en tydelig Erosionsterrasse, hvor Strandgru- 
set naar til $3.4 \mathrm{~m}$ o. H. Gennem den brede Dal ved Fiskbæk Aa har Fjorden strakt sig sydpaa omtrent til Jernbanelinjen. Usandsynligt er det ikke, at det salte Vand er naaet videre ind og har dækket den brede, kun $2^{1 / 2} \mathrm{~m}$ o. H. liggende Engstrækning omkring Bredsgaard Sø, men direkte Vidnesbyrd derom haves ikke.

I Stenalderhavets Tid har den inderste Del af Hjarbæk Fjord haft et andet Udseende end nu, idet to betydelige Fjorde har strakt sig ind mod Øst $\mathrm{i}$ de brede Dale langs Skals Aa og Simested Aa. Den store, glaciale Floddal langs Skals Aa har dog ikke i hele sin Bredde været dækket af Saltvand; dette er kun naaet ind over de laveste Partier midt i Dalen. Til Trods for den lange og smalle Vej herfra ud til den aabne og salteste Del af Limfjorden, har Molluskfaunaen dog været temmelig rig, hvad der ses dels i de hævede marine Lag i den tidligere Fjordbund, dels $\mathrm{i}$ en Stenalders Affaldsdynge ved Foden af Bakkerne Sydvest for Skals. De marine Lag følges med Lethed op til Løvel Bro, hvor Hovedlandevejen passerer Dalen Sydvest for Bjerregrav; men om Fjorden er naaet længere ind, og da hvor langt, har ikke kunnet bestemmes. Ved Løvel Bro maa Fjorden i alt Fald have været meget smal, men ogsaa temmelig dyb. Øst herfor liggere Engene 3.7-4 m o. H., men Tørvelaget har saa betydelig en Mægtighed, at de derunder værende Lag for en stor Del ligger under Havets Niveau, og i Litorinatiden har de altsaa ligget endnu dybere. Eksempelvis kan nævnes, at der i Engen mellem Hersom og Rødsø, $4 \mathrm{~m} \mathrm{o.} \mathrm{H.,} \mathrm{fandtes} 5.3 \mathrm{~m}$ Tørv og derunder Sand. Ogsaa andre Boringer i disse Enge viste kun Sand under Tørven, men gav ingen Oplysning om, hvorvidt dette Sandlag var af marin Oprindelse. Da den faste Sandbund (under 'Tørvelaget) mellem Rødsø, Hersom og Hærup Sø ligger saa lavt, i Stenalderhavets Tid indtil $3 \mathrm{~m}$ under Havets Niveau, er der dog næppe Tvivl om, at det salte Vand er trængt herind, og at man ved en mere detailleret Undersøgelse vil kunne paavise marine Dyreformer $\mathrm{i}$ de dybere liggende Lag $\mathrm{i}$ alt Fald op til Hærup Sø. Videre mod Nordøst mellem Hærup Sø og Kleitrup Sø aftager Ferskvands-Alluviet i Mægtighed, samtidig med at Dalbundens Højde over Havet stiger stærkere, saaledes at den faste Bund - med Undtagelse af en ganske smal Rende - ligger over Havets Niveau. Her vil der derfor næppe kunne findes Fjordaflejringer fra Litorinatiden.

Fjorden langs Simested Aa mellem Skals og Laastrup har ved sin Munding haft stor Bredde, og udstrakte Arealer langs den lavvandede, indre Del af Hjarbæk Fjord er nu tørlagte. Indad i Landet har Simested-Fjorden derimod været temmelig smal og har kun strakt sig $5-6 \mathrm{~km}$ ind i Højlandet.

Fra Lovns Bredning, mellem Virksund og Hvalpsund, har flere 
Vige strakt sig ind i Landet mod Øst. Lavningen mellem Ulbjerg og Gjedsted har været en stor, aaben Bugt. Under Landhævningen har Strandvolde lagt sig fra Syd til Nord og omdannet Bugten til en Lagune; inde i denne, ved Hjorthøje, ses en meget velbevaret Erosionsterrasse i Bakkefoden $4.7 \mathrm{~m}$ o. H. Strandvoldene, der bestaar af Strandsten og Skalgrus naar til 4.4-4.7 m o. H.

Nord for Gjedsted, mellem denne By og Ullids, har en Fjord strakt sig ind gennem den brede Dal omkring Lerkenfeld Aa. Her, hvor Saltholdigheden i Fjorden har været større end inde i Hjarbæk Fjords indre Del, har ogsaa Betingelserne været gunstigere for Udviklingen af et rigt Dyreliv. I den hævede Fjordbund og i Strandvoldene mellem Gjedsted og Ullids er Mængden af Muslingeskaller da ogsaa usædvanlig stor; i de senere Aar foretages der en fabrikmæssig Udgravning og Bearbejdning af disse Skalmasser, der anvendes til Hønsefoder. I 1917 solgtes der herfra 5 Millioner kg Skaller.

Nord for Hvalpsund er der ikke sket væsentlige Forandringer i Kystlinjens Beliggenhed. Udenfor de gamle, nu græsdækkede Kystskrænter er der paa mange Steder dannet nyt Land, men oftest kun som en smal Bræmme. En tidligere Fjord ved Stistrup Aa, Vest for Farsø, er bleven afspærret ved Strandvolde og tørlagt, og Syd for Ærtbølle Hoved er der vokset brede, lavtliggende Strandenge op udenfor den gamle Kyst.

Omtrent en Kilometer Sydøst for Ertbølle Hoved ligger den kendte og omhyggelig undersøgte, store Affaldsdynge fra den ældre Stenalder ${ }^{1}$ ). I Beskrivelsen af denne Affaldsdynge omtales, at den gamle Kystlinje, Grænsen mellem Bakkeskraaning og Strandenge, paa dette Sted ligger i en Højde af $4.5 \mathrm{~m}$ o. H., og at Affaldsdyngen er aflejret saavel op ad Skraaningen som paa Strandgruset nede paa Strandfladen. Dyngen maa altsaa - i alt Fald for den ydre Dels Vedkommende - være dannet efter Litorina-Sænkningens Maksimum paa en Tid, da Landet allerede var hævet noget. Det omtales endvidere, hvorledes der inde i Affaldsdyngen findes Lag af Strandsten og Strandsand i forskellig Højde, paa et Par Steder endog to saadanne Lag oven over hinanden med en indbyrdes Afstand af $0.1-0.6$ m. Sophus Müller skriver (anf. St. Side 17): „Disse Lag af smaa Strandsten, Grus og Sand, som strække sig ind fra Fjordsiden, yderst med størst Mægtighed og liggende over Skallaget, indadtil aftagende i Tykkelse og bredende sig gjennem Laget eller under det, bestandig mere nærmende sig Bunden [Bunden skraaner jævnt opad mod Bakke-

${ }^{1}$ ) A. P. Madsen, Sophus Mëller, Carl Neergaard, C. G. Joh. Petersen, E. Rostrup, K. J. V. Steenstrup, Herluf Winge. 1900. Affaldsdynger fra Stenalderen i Danmark. Kjøbenhavn. 
skræntens Fod], indtil de ophøre i Strækningen mellem Dyngens Midte og Strandbrinken, maa antages at være aflejrede af Havet ved flere, noget højere Vandstande«. Under Beskrivelsen af Affaldsdyngen ved Aamølle ved Mariager Fjord (anf. St. Side 94-95) omtales lignende Grusstriber i Skalmassen, og i det geologiske Afsnit forklarer K. J. V. Steenstrup dem som fremkomne ved, at Aavandet om Foraaret ved Tøbrud er steget op over Dyngen og har skyllet Grus ind over den. Imidlertid tilføjer han i en Note: „Ovenstaaende, der er nedskrevet umiddelbart efter Undersøgelsen i 1893 er maaske vel meget paavirket af Frygten for, uden gode Beviser at antyde en Sænkning under Skaldyngernes Dannelse. ..... Senere har Ertebølle-Dyngen jo utvivlsomt vist, at en Sænkning har fundet Sted«. Dette er utvivlsomt ikke rigtigt. Ligesom ved Aamølle maa Gruslagene i Ærtbølle Dyngen forklares ved Indvirkningen af lokalt Højvande, der jo er et ret almindeligt Fænomen i Limfjorden. Ved en Landsænkning vilde der være fremkommet et enkelt Gruslag, der strakte sig gennem hele Dyngen, og ikke forskellige Gruslag i forskellig Højde, mindst af alt to Gruslag over hinanden. Skallerne under Gruslaget vilde endvidere ved den længere Tids Paavirkning af Bølgeslaget være blevet omlejrede, rullede og sorterede efter Størrelse ligesom i en Havstok, og endelig vilde en saadan Landsænkning med efterfølgende Landhævning, saaledes at Stenalderfolket atter kunde tage den ny Strandbred i Besiddelse, fordre et saa langt Spand af Tid - mulig lige saa lang Tid som er medgaaet til Aflejringen af hele Affaldsdyngen - at det rimeligvis vilde have givet sig til Kende i Mængdeforholdet mellem de forskellige Redskabstyper under og over Gruslagene.

Mellem Ertbølle Hoved og Bjørnsholm har to betydelige Fjorde naaet langt ind i Landet, dels langs Trendaa, dels langs Bjørnholm Aa. Mellem Mundingerne af disse Fjorde findes der mellem den gamle og den ny Kystlinje en indtil $1 \mathrm{~km}$ bred, svagt skraanende, lyngdækket Strækning, der bestaar af usædvanlig smukt udviklede, stenede Standvolde. De lange, skarpe Grusrygge breder sig vifteformet ud fra Syd mod Nord, og Voldenes Højde stiger jævnt nede fra den nuværende Havstok paa 1.5 -2.0 Meters Højde op indtil de øverste Strandvolde, hvis Rygge ligger indtil 6.s $\mathrm{m} \mathrm{o.} \mathrm{H}$.

Fjorden, der tidligere har udfyldt Dalen Nordøst for Bjørnsholm, har strakt sig mod NØ til Vilsted og Vilsted Sø. En lille Vig er naaet mod Nordvest omtrent ind til Ranum, og et Par andre Vige har fra Vilsted Sø strakt sig endnu videre ind i Landet mod Øst og Sydøst.

Længst mod Nord ved Aggersund findes der (som omtalt Side 35) Syd for Færgestedet meget iøjnefaldende Strandvolde til en Højde af $6.3-6.6 \mathrm{~m}$ o. $\mathrm{H}$. 


\section{Fra Aalborg til Mariager Fjord.}

Den østligste Del af Limfjorden, fra Aalborg til Hals, eksisterede ikke som saadan under Litorina-Sænkningens Maksimum. Stenalderhavet dækkede de lave Mose- og Engstrækninger baade Nord og Syd for den nuværende Limfjord og naaede som en bred, aaben Bugt fra Kattegat ind til Bakkerne ved Aalborg. Den daværende Fordeling mellem Land og Hav i det sydøstlige Vendsyssel er omtalt Side 31. Landet Syd for Aalborg var, da Landsænkningen var størst, delt i fire større og nogle mindre Øer, adskilte ved smalle Sunde. Lille Vildmose og Strandengene udenfor denne, saavel ud mod Limfjorden som ud mod Kattegat, var dækkede af Havet, og op over dette hævede sig kun et Par Smaaøer, Tofte Bakke i den sydlige Del af Vildmosen og Muldbjerge Øst for Mosen, ude ved den nuværende Kyst.

Den store Havbugt $\varnothing$ st for Aalborg maa have haft en temmelig ringe Vanddybde; største Delen af det ved den senere Landhævning tørlagte Areal bestaar nemlig af Strandsand, der har en overordentlig plan Overflade. Noget Fald ud mod den nuværende Kystlinje kan næppe paavises, og dette maa have været en medvirkende Grund, maaske Hovedaarsagen til, at der paa disse Arealer er opstaaet betydelige Moser, Lille Vildmose mod Syd og Hals Mose Nord for Fjorden. Desuden findes der paa begge Sider af Limfjordens Munding store Systemer af Rimmer og Dopper, fra Mundingen af Gjeraa Syd paa til hen imod Hals, og fra Muldbjerge vifteformet Nord paa til Egense og Mov, altsaa Terrainformer, der næppe kan tænkes opstaaede paa andre Steder end langs en lav Kyst med et meget fladt Farvand udenfor, hvor selv en ubetydelig Landhævning vilde tørlægge en forholdsvis bred Landstrimmel.

Stenalderhavets Kystlinje, den skarpe Grænselinje mellem Bakker og Sletteland, er i denne Egn meget iøjnefaldende, i Særdeleshed paa den ud mod Kattegat vendende Side af Bakkerne, der er stærkt paavirket af Havets nedbrydende Virksomhed. Muldbjerge, f. Eks., er aabenbart kun den vestligste Rest af et større Bakkeparti, der lidt efter lidt er skaaret bort af Havet. Stejle Kystskrænter ses ogsaa paa Østsiden af Smidie Bakkeø, hvor Skrivekridtet er blottet ved Erosionen, og hvor det nu brydes i Gange, der fra Bakkefoden føres horizontalt ind i Bakken. Endvidere Nord herfor ved Kongstedlund Bakke og Øst for Nørre Kongerslev, paa Østsiden af den lille Gudumlund Bakkeø og ikke mindst paa Østsiden af den store Bakkeø mellem Romdrup, Storvorde og Gudum, Middelalderens Gudingholm. Østsiden af dette Højdedrag er stejl og saa retlinjet, som var den skaaret med en Kniv, og paa mange Steder skinner det hvide 
Skrivekridt frem gennem Græsdækket. Her anlagdes i Slutningen af det 18de Aarhundrede Kalkovne og forskellige Fabriker, og Gudumlund Kanal - den nedre Del af Lindenborg Aa - gravedes ud til Limfjorden for at lette Besejlingen og Udskibningen.

Højtliggende Strandlinjer er i dette Terrain ikke saa almindelige, som man skulde vente; paa de aabne Kyster ud mod Kattegat har Havets Erosion nemlig virket ogsaa under Landhævningen, hvorved de ældste og højeste Strandmærker gravedes bort og erstattedes af yngre, lavere liggende. Dette ses f. Eks. ved Muldbjerge; her findes paa den nogenlunde beskyttede Vestside ind mod Vildmosen en meget skarp og tydelig Strandlinje 7.8-7.9 m o. H., hvorimod Strandlinjen paa Østsiden ud mod Kattegat næppe ligger $4 \mathrm{~m} \mathrm{o}$. H. Paa andre Strækninger har den stærke Vækst af Tørvemoserne skjult de gamle Havstokke. Enkelte Undtagelser findes dog; saaledes ses ved Foden af Bakken ca. $1 \mathrm{~km} \varnothing \mathrm{\varnothing N}$ for Nørre Kongerslev en stor Strandvold af Grus og Strandsten med en Højde af $6.3-6.9 \mathrm{~m} \mathrm{o.} \mathrm{H.}$ I samme Højde $(6.3 \mathrm{~m})$ kan man herfra og Syd paa til Smidie følge den gamle Kystlinje, dog kun hvor Strandsandet ligger udækket nedenfor Bakkeskrænten og ikke dækkes af yngre Tørvedannelse.

Medens de marine Aflejringer paa de aabne Strækninger ud mod Kattegat hovedsagelig bestaar af Strandsand, findes inde i de tidligere Fjorde og Sunde Syd for Aalborg dels Ler, dels Dynd, hyppig fyldt med Skaller af marine Mollusker. Som Regel er de marine Lag her dækkede af Tørv eller Ferskvandsdynd, ofte af betydelig Mægtighed.

I det Sund, der fra Aalborg strakte sig Syd paa ind mellem Bakkerne langs Østeraa, og paa hvis Bund den gamle Del af Aalborg er bygget, vil man i større Udgravninger i og udenfor Byen finde dette Litorina-Ler med dets rige Fauna; enkelte Steder har det endog Karakter af Østersbanker. Det hviler som Regel paa Sand eller paa senglacialt Yoldialer, men kan ogsaa paa sine Steder være aflejret oven paa Tørvemoser fra Fastlandstiden.

Ca. $5 \mathrm{~km}$ Syd for Aalborg har dette Sund staaet i Forbindelse dels med Limfjorden Vest for Aalborg ved et bredt Sund mellem Hasseris og Freilev, dels med den tidligere Aalborg-Bugt (og Kattegat) ved et smallere Sund, der løber forbi Gug og Sønder Tranders. Her vil man paa talrige Steder, f. Eks. i Engene SV for Sønder Tranders, hvor Overfladen ligger $6^{1} / 2 \mathrm{~m}$ o. H., finde øverst $1-2$ $\mathrm{m}$ Tørv, og derunder marint Ler og Dynd med store Mængder af Skaller.

Følger man Fjorden langs Østeraa videre Syd paa, vokser Mægtigheden af den over de marine Lag liggende Tørvedannelse. Vest for Ferslev, ved Bonderup Bro, har Fjorden været meget smal, 
Strømmen stærkere og Leraflejringen derfor ringe. En Boring, hvor Overfladen laa $6.9 \mathrm{~m}$ o. H., viste

$$
\begin{array}{ll}
3.8 \text { m } & \text { Tørv. } \\
0.5 \text { " Lag af tætpakkede Skaller. } & \text { Nederst groft Strandsand. }
\end{array}
$$

Noget sydligere, hvor Fjorden atter har været bredere, finder man under $3.8 \mathrm{~m}$ Tørv 1.6-2.5 m marint, skalførende Ler og derunder groft Sand eller Kridtgrus. I Engen VSV for Volsted, hvor Overfladen ligger $7.5 \mathrm{~m} \mathrm{o}$. H., fandtes $4.4 \mathrm{~m}$ Tørv og derunder mere end $7^{1 / 2} \mathrm{~m}$ marint Ler med en Mængde Skaller.

Medens den egentlige Aalborg-Fjord kan følges videre mod SSV, hvorom senere, har et Sund Syd for Voldsted By ført ud mod Øst gennem den dybe Dal, i hvilken Lindenborg Aa nu løber. Mellem Volsted og Skjørping By er dette Sund temmelig smalt; her hvor Overfladen ligger $6.6 \mathrm{~m}$ o. H. fandtes

$$
\begin{aligned}
1.9 \mathrm{~m} & \text { Ferskvandsgytje. } \\
0.6 ” & \text { Strandsand med Skaller. } \\
& \text { Derunder mere end } 2 \mathrm{~m} \\
& \text { marint Dynd med Skaller. }
\end{aligned}
$$

Længere mod Øst, SØ for Volsted, hvor Overfladen ligger $6.9 \mathrm{~m}$ o. H., fandtes

$$
\begin{aligned}
& 3,5 \mathrm{~m} \text { Tørv. } \\
& 5.3 \text { " marint Ler med Skaller. } \\
& \\
& \text { Derunder Sand og Grus. }
\end{aligned}
$$

Endnu længere Øst paa, ved Lindenborg, har Sundet været bredere og Faunaen i de marine Lag rigere. Her ude forenedes Sundet med det i N-S løbende, brede Sund, der skilte Romdrup-Storvorde-Gudum Øen fra den vestligere $\varnothing$. I dette sidste Sund maa Vandets Saltholdighed have været betydelig, idet Faunaen i de marine Lag er meget righoldig; i de store Grøfter, der gennemskærer Engene ses paa mange Steder betydelige Lag af Strandskaller.

Ud for det Punkt, hvor dette Sund og Lindenborg Sundet forenedes, ligger ved Gudumlund den lille Banke, paa hvis Sydspids der 7-9 $\mathrm{m}$ o. H. findes en Affaldsdynge fra den ældre Stenalder. Affaldsdyngen, der ligger, hvor nu Vejen fører ned ad Bakken Syd paa ud over Lavlandet, har været kendt i lang Tid. Første Gang nævnes den vistnok af BREDSDORFF 1824, der omtaler Østerskallerne, som han anser for sammenskyllede af Havet, »dog har Havet til Stadighed næppe staaet saa højt $\left.\ll^{1}\right)$. At Lille Vildmose har været Hav,

$\left.{ }^{1}\right)$ J. H. Bredsdonff. 1824. Geognostiske og mineralogiske Iagttagelser paa en Rejse i Nørre-Jylland i Juli og August 1823. Tidsskr. for Naturvidensk. III. Kjøbenhavn. 
nævner han ogsaa. Senere omtales Affaldsdyngen i flere arkæologiske og zoologiske Afhandlinger og benyttes som Bevis paa de store Forandringer i Landets Kystform, der maa være foregaaede siden den ældre Stenalder. Affaldsdyngen ligger nu $10 \mathrm{~km}$ fra Kattegats Kyst.

Som ovenfor nævnt fortsattes den egentlige Aalborg-Fjord fra Volsted videre mod SSV ind forbi Buderupholm og Gravlev. En Boring ved Buderup Bro, tæt ved Kirken, hvor Overfladen ligger $6.9 \mathrm{~m}$ o. H. viste

$0.3 \mathrm{~m}$ Tørv.

5.8 ,Ferskvandsgytje.

Derunder mindst $6 \mathrm{~m}$ marint Dynd med Skaller.

I den nu udtørrede Gravlev Sø fandtes ØNØ for Gravlev Kirke, hvor Overfladen ligger $7.0 \mathrm{~m} \mathrm{o}$. $\mathrm{H}$.

$4.4 \mathrm{~m}$ Ferskvandsgytje og Ferskvandskalk.

3.1 " marint Dynd med Skaller.

Derunder mere end $4.2 \mathrm{~m}$ Tørv.

Omtrent $2 \mathrm{~km}$ Syd for Gravlev Kirke, Syd for Landevejen ved Tinbæk Vandmølle, fandtes

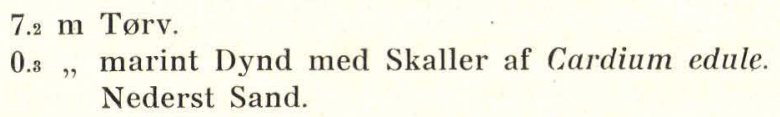

Længere kunde det marine Lag ikke følges, men man maa undres over, at det salte Vand dog har kunnet naa saa langt ind $(27 \mathrm{~km}$ fra Aalborg) gennem en bugtet og paa sine Steder meget smal Fjord.

Ikke alene den nu lyngdækkede »Lille Vildmose", der hviler paa marint Sand og Ler, men ogsaa det udstrakte Sletteland Syd herfor indtil Mariager Fjord var i den ældre Stenalder dækket af Havet. Enkelte isolerede Banker ragede op som Øer. Muldbjerge mellem Vildmosen og Kattegat er allerede omtalt; med sin betydelige Højde, $48 \mathrm{~m}$, og sine karakteristiske Konturer virker dette lille Bakkeparti meget ejendommeligt ude i det flade, ensformige Landskab. En anden isoleret Banke findes sydligere i Mosen, ved Tofte. Ogsaa den har tidligere været en $\varnothing$; men som Følge af det omgivende Havs ringe Dybde eller beskyttende Banker foran er den tidligere $\varnothing$ ikke blevet saa stærkt medtaget ved Havets Angreb. Den gamle Kystlinje ses dog tydeligt paa Bakkens Østside i en Højde af $6-6.3 \mathrm{~m}$ o. H. Vest derfor fandtes et Par større Øer, de nuværende stejle Kridtbakker ved Kongstedlund og ved Smidie. De adskiltes fra hinanden og fra Fastlandet ved temmelig brede Sunde, i hvilke der nu i Leret og Dyndet under Tørvelagene findes talrige Rester af den marine Fauna. 
Det lave, flade Land Syd for Vildmosen bestaar dels af marint Strandsand, dels af fugtige Kær med større og mindre Krat og Skovpartier. Østligst mod Kattegat har der ligget en Række Øer, nordligst nogle smaa, lave Holme ved Hurup, Syd derfor en større Ø ved Als. og sydligst en lille, toppet Holm ved Helberskov. Bankerne ved Als og Helberskov staar nu med stejle Skrænter baade mod Øst og Vest og har været stærkt udsatte for Havets Angreb. Fra Nordenden af den tidligere Als- $\varnothing$ udgaar der mod Nordvest et System af Strandvolde, hvoraf de fleste nu er dækkede af Flyvesand; dog kan Strandgruset ved Haslev Gaarde følges til en Højde af 6.3-6.6 $\mathrm{m}$ o. $\mathrm{H}$.

Fastlandets gamle Kystlinje, der kan følges Syd paa til Vedum og Skelum, er ikke saa udpræget som længere mod Nord. Havets Angreb har paa denne, af den ydre Ørække beskyttede Strækning, kun paa ganske enkelte Steder været saa stærkt, at det har sat sig varige Spor, saaledes f. Eks. paa Østsiden af Bratbjerg Syd for Skelum, hvor en tydelig Kystlinje (Erosionsterrasse) 5.3-5.6 m o. H. kan følges herfra mod Syd til Sandgaard. Det sidstnævnte Parti fra Skelum til Sandgaard var iøvrigt i Stenalderen en Ø, adskilt fra Landet Vest derfor ved smalle Sunde. Herfra har desuden en Fjord strakt sig videre Vest paa, temmelig langt ind i Landet $\mathrm{N}$ for Visborg Gaard; ved Boring er marint Ler og Dynd fulgt ind langs Korrup Aa til Korrup Mølle ved Hadsund-Aalborg Landevej. Blandt andet kan nævnes, at i Møgelmose, NV for Visborg Gaard, har de marine Lag, der dækkes af $1-1^{1 / 2} \mathrm{~m}$ Tørv, en Mægtighed af $3 \mathrm{~m} \mathrm{og}$ naar til en Højde af $4.4 \mathrm{~m} \mathrm{o}$. H. Sydligst, umiddelbart ved Mariager Fjord, ligger ved Gaarden Havnø en lille, $13 \mathrm{~m}$ høj Banke, en tidligere $\varnothing$; paa Bankens Sydside findes den fra den æeldre Stenalder hidrørende, kendte Affaldsdynge, der oprindelig, da den endnu var urørt, havde en Længde af over $600 \mathrm{~m}$ og en Bredde af godt $20 \mathrm{~m}$. Marken, hvorpaa Affaldsdyngen er ophobet, ligger 6.3 -6.6 m o. H., altsaa noget over den Højde $\left(5-5^{1 / 2} \mathrm{~m}\right)$, hvortil Bølgeslaget kan antages at have virket paa dette Sted i Litorinatiden. At Mariager Fjord i den ældre Stenalder var et søgt Opholdssted for den Tids Jæger- og Fiskerfolk, fremgaar af den Mængde Affaldsdynger, der er fundne langs de tidligere Fjordbredder. Langs Sydranden af Bjergbakke, S for Visborg, findes en Række Affaldsdynger; ved Hadsund samt tæt Øst derfor paa Nordsiden af Fjorden og Sydøst derfor paa Sydsiden af Fjorden findes ligeledes adskillige Dynger. Endvidere ved Tygeslund, Vivebrogaard, Aamølle og ind gennem Fjorden lige til Hobro, hvor der er paavist en Stenalders-Affaldsdynge tæt udenfor Byen.

Kystlinjerne langs Mariager Fjord fra Hadsund ind til Hobro 
har i det væsentlige holdt sig uforandrede siden Stenalderen. Enkelte mindre Vige er blevet tørlagte, og paa flere Steder har Strandgruset samlet sig som Odder og Næs. Kun Vest for Hobro er Forandringen betydelig, idet Fjorden i Stenalderen har strakt sig et Stykke videre mod Sydvest op gennem Dalen langs Onsild Aa, omtrent til Byen Øls.

Hævede Havstokke er ret almindelige langs Bredden af Mariager Fjord indenfor Hadsund. Paa Fjordens Nordside ved Nybro Gaard SV for Hadsund bestaar saaledes hele den fremspringende, lille Halvø af grusede og stenede Strandvolde, hvis Rygge ligger indtil $4.4 \mathrm{~m} \mathrm{o}$. H. Paa den anden Side af Fjorden, ved Aamølle, er den lille Vig, der tidligere har strakt sig ind mod Syd, blevet lukket ved en bred, stenet Havstok, hvis øverste Del nu naar 3-4 m o. H., og paa hvilken der ligger en Affaldsdynge fra den xldre Stenalder. Beliggenheden af denne Affaldsdynge, der for en Snes Aar siden er blevet meget omhyggelig undersøgt, viser, at den er ophobet efter Litorina-Sænkningens Maksimum paa et Tidspunkt, da Landhævningen var saa vidt fremskredet, at den i.Aamundingen opkastede Strandvold ikke under normale Forhold overskylledes af Bølgerne. At de i Skalmassen forekommende Gruslag ikke kan betragtes som Bevis paa en Landsænkning, men maa skyldes lokalt Højvande enten i Aaen eller i Fjorden, er omtalt Side 72 .

Tæt Sydvest for Aamølle findes Rester af en nu delvis bortgravet Strandvold, hvis Ryg ligger $5.3 \mathrm{~m} \mathrm{o.} \mathrm{H.} \mathrm{Længere} \mathrm{indad} \mathrm{langs} \mathrm{Fjor-}$ den findes Strandgrus, dels som Strandvolde, dels som Terrasser op mod Bakkesiderne, til Højder paa $4.4-4.7 \mathrm{~m} \mathrm{o}$. H., saaledes $\mathrm{NV}$ for Falslev Kirke, $\mathrm{N}$ for Hov Skov og videre hen imod Mariager. Ved Fladbjerg Nord for Hov Skov findes desuden en stor, bred Strandvold af ægstore Sten, der naar til $5.6 \mathrm{~m} \mathrm{o.} \mathrm{H.;} \mathrm{ved} \mathrm{Voldens} \mathrm{Nordende}$ kan Gruset endog følges til $6.0 \mathrm{~m}$ o. H. Om denne Strandvold er postglacial, er ikke absolut givet; mulig er den senglacial. Dens Beliggenhed er imidlertid en saadan, at man netop paa dette Sted, der ligger ret udsat for vestlige Vinde ud gennem Fjorden, maa vente at finde postglaciale Stranddannelser til et noget højere Niveau end sædvanlig i denne Del af Mariager Fjord. Derimod tør man vistnok gaa ud fra, at et Par andre Strandvolde, der naar til endnu større Højder, ikke er postglaciale, men senglaciale, og saaledes Vidnesbyrd om, at Landsænkningen ved Istidens Slutning endnu saa langt Syd paa som ved Mariager Fjord har været større end den senere (postglaciale) Stenaldersænkning. VSV for Gaarden Blæsborg, SV for Aamølle, ses saaledes yderst en postglacial Havstok, i hvilken der graves Grus, og indenfor denne en kort Strandvold, der udgaar fra Syd og støtter sig til Bakken som en smal Accumulationsterrasse. 
Dens Højde er 6.3-6.6 m o. H. Noget østligere, NV for Ballega ard og $\mathrm{N} \varnothing$ for Landsbyen Assens, strækker der sig fra Vest mod Øst en høj og bred Strandvold, der dog nu er stærkt ødelagt ved Bebyggelse og Grusgravning. Gruset naar mod Vest ved Strandvoldens Rod indtil $6.6 \mathrm{~m} \mathrm{o.} \mathrm{H.}$

Noget Bevis for, at Strandvoldene ved Blæsborg og Ballegaard er senglaciale, haves ikke og kan vanskelig gives. De ligger imidlertid paa et Sted, hvor Bølgeslaget hverken nu eller i Stenalderhavets Tid kan have været af Betydning; og da endvidere deres Højde er saa usædvanlig og ikke staar i Forhold til de omgivende, utvivlsomt postglaciale Havstokkes Højde, kan de næppe være dannede af Stenalderhavet. Allerede i 1842 og i flere senere Afhandlinger offentlig. gør Forchнамmer Maalinger af hævede Havstokke ved Mariager Fjord, dels af utvivlsomt postglaciale Havstokke, dels af Strandvolden ved Ballegaard, og anfører de meget forskellige Højder uden at tage synderligt Forbehold. Dette benytter E. Ersuev senere til i 1886 at rette et iøvrigt uberettiget Angreb paa Forchnammers Teori om den fra NØ mod SV aftagende Landhævning, hvorefter han selv begaar en langt større Fejl ved udelukkende efter Terrainformerne at slutte, at Havet i postglacial Tid har bredt sig over Omraader og til Højder, hvortil det aldrig har naaet.

Grunden til, at Kysterne langs den indre Del af Mariager Fjord har holdt sig saa uforandrede fra Stenalderen indtil Nutiden trods den ret betydelige Landhævning, maa søges i de stejle Bredder. Landet er højt paa begge Sider af Fjorden og falder brat ned mod denne; langs Bakkefoden er der oftest kun en smal Strandbred og en meget smal Bræmme med lavt Vand, saaledes at man allerede $\mathrm{i}$ ganske kort Afstand fra Kystlinjen naar ud paa dybt Vand. I flere Henseender indtager Mariager Fjord en Særstilling. Saaledes er Kolding Fjord, Vejle Fjord og Horsens Fjord tragtformede med vid Munding; i disse Fjordes inderste Del har Aaløbene udfyldt større eller mindre Partier med deres Slam, og herfra tiltager Dybden nogenlunde jæunt ud mod Fjordmundingen. Randers Fjord er i sin indre Del fuldstændig udfyldt af Sediment, og i den ydre Del danner en smal Rende Gudenaaens Fortsættelse ud til Kattegat. Mariager Fjord bestaar derimod af et indre, bredt og dybt, bassinformet Parti mellem Hobro og Hadsund, og et ydre Parti, der har samme Karakter som den ydre Del af Randers Fjord. Det indre Bassin har som næevnt stejle Sider og betydelig Dybde, størst udfor Mariager, hvor Dybden i Følge Generalstabskortet er 37.6 m (»Danske Lods « angiver Dybden til $28 \mathrm{~m}$ ). Bassinet strækker sig Øst paa til Aamølle, hvor der tværs over Fjorden ligger en Barre (af glacial Oprindelse?) med kun $2^{1 / 2} \mathrm{~m}$ Vand før Uddybningen. Herfra og ud til Kattegat er Fjorden overordent- 
lig grund, og store Strækninger kan ligge tørre ved Lavvande; en stærkt bugtet, nu reguleret og uddybet Rende fører fra Aamølle ud gennem dette flade Parti. Rendens Bredde er i Fjordens yderste Del meget ringe, næppe større end Gudenaaens ved Randers, og dens Dybde meget varierende, fra 4 til $10 \mathrm{~m}$. Gennem disse Forhold forklares det, at der - trods den ringe Forskel i Landhæuningens Størrelse langs Fjordens indre og ydre Del - dog er en saa overordentlig stor Forskel paa Udstrækningen af de siden Stenalderen tørlagte og nydannede Landarealer i de to Omraader.

Hele det lave Kystland, der strækker sig langs Kattegat omtrent fra Dronninglund i det sydøstlige Vendsyssel, over Limfjorden, Lille Vildmose, Landet ned mod Mariager Fjord, dennes yderste Del og videre over de udstrakte Strandenge Syd paa til Randers Fjord, danner en usædvanlig jævn og plan Sandslette, hvis Højder kun ligger faa Meter over eller under Havets Niveau. Underlaget for de postglaciale Dannelser er mod Nord omkring Limfjordens nuværende, østlige Munding dels senglacialt Ishavsler (Yoldialer), dels senglacialt Ishavssand. Yoldialeret, der kun findes over mindre Arealer, er fulgt Syd paa til Muldbjerge, det sydligste Punkt her i Landet, hvor denne Lerart hidtil er paavist. I den sydlige Del af Slettelandet hviler de postglaciale Lag enkelte Steder paa flade Banker af Moræneler, men som Regel paa glaciofluvialt (senglacialt?) Sand. Det ligger da nær at formode, at denne store, næsten plane Slette er dannet i senglacial Tid, dels under dels over Havet, som en Bræmme foran den bortsmeltende Indlandsis, hvis Rand rimeligvis har strakt sig fra Djursland til Vendsyssels Højland. I visse Henseender kan maaske derfor det sammenhængende Sletteland fra Vendsyssel til Randers Fjord betegnes som en senglacial Hedeslette (delvis som en submarin Randterrasse), hvis Dannelse dog ikke er naaet saa vidt, at de fra Isen udskyllede Sandmasser har formaaet ogsaa at udfylde den indre Del af Mariager Fjord. Det fine Ler er for største Delen ført Nord paa med den over det sydlige Vendsyssel udgaaende Smeltevandsstrøm og aflejret der som Yoldialer.

\section{Fra Mariager Fjord over Djursland til Aarhus. Anholt.}

Mellem Mariager Fjord og Randers Fjord har Stenalderhavets Kyst ligget langt indenfor Nutidens. Kystlinjen strakte sig fra Overgaard mod Syd forbi Udbynedre, Dalbynedre og Demstrup. Hele det udstrakte Sletteland Øst herfor var dækket af Havet, og kun et Par 
smaa Banker, ved Bjerge og ved Sødring, ragede op som Øer. Blandt disse Holme har i Særdeleshed Banken ved Sødring været udsat for stærk marin Erosion; dens Østside staar nu som en stejl, indtil $20 \mathrm{~m}$ høj Kystskrænt, i hvis Fortsættelse Strøm og Bølgeslag har bygget Strandvolde ud mod NNØ og SSV. Disse Strandvolde er nu dækkede af Flyvesand, der i det hele taget har omformet Terrainet her omkring.

Indenfor Holmene ved Sødring og Bjerge, har Havet næppe været ret dybt. Den gamle Kyst fra Overgaard ved Mariager Fjord til Raaby ved Udbyhøj er kun paa enkelte Strækninger udformet som en stejl Kystskrænt, og Stranddannelser af groft Materiale, Grus eller Sten, savnes langs Bakkefoden. Bølgeslaget kan derfor ikke paa denne Strækning have haft synderlig Kraft, til Trods for Beliggenheden direkte ud mod Kattegat. En skarp Modsætning hertil danner den retlinjede, gamle Kyst, der fra Udbyhøj ved Mundingen af Randers Fjord strækker sig mod Sydøst forbi Estruplund til Hevring. Paa den nordligste Strækning staar denne Kyst som en høj og stejl Skrænt, der ved Ingerslev Bjerge endog naar til en Højde af $40 \mathrm{~m}$ over Lavlandet. Den marine Erosion har her været usædvanlig stærk og er, da Bakkefoden kun ligger et Par Meter over Havet, fortsat indtil meget sen Tid. Længere Syd paa, hvor Bakkerne er lavere, er Erosionen paa et tidligt Tidspunkt afløst af Accumulation; der er her udenfor og parallelt med den gamle Kystskrænt aflejret Strandvolde, der mod Syd fjærner sig mere og mere fra Højlandet. Disse Strandvolde, der nu for en Del er dækkede af Flyvesand, har i Forbindelse med et fra Kysten Nord for Hevringholm udgaaende, vifteformet System af Strandvolde søgt at lukke det Sund, der i Stenalderen førte fra Hevringholm mod Vest ind til Randers Fjord. Strandvoldene mellem Estruplund og Hevring By naar til en Højde af 6-6.5 m o. H.; trækkes herfra den Højde, hvortil Bølgeslaget kan kaste Grus op paa en saadan Kyst som denne, faas en Landhævning fra Strandvoldenes Dannelse (i Stenalderen) og til Nutiden paa ca. $4 \mathrm{~m}$.

Inde $\mathrm{i}$ den egentlige Randers Fjord $^{1}$ ) har Erosionen været af langt ringere Betydning end ude ved den aabne Kattegatskyst. I Hovedsagen havde Dalsiderne allerede faaet deres nuværende Profil i Slutningen af Istiden; det er den brede U-formede, glaciale Floddal, man endnu ser. Kun i det smaa har de marine Forhold i Litorinatiden kunnet præge Landskabet. Undtagelsesvis er der aflejret Strandvolde eller skyllet bort af Bakkerne; almindelig og af størst

1) A. Jessen. 1917. Udstrækningen af Randers Fjord i Litorinatiden; se A. C. JoHANSEN. 1918. Randers Fjords Naturhistorie. København. 
Betydning er derimod Aflejringen af Ler og Dynd paa den gamle Fjordbund, ofte oven paa Fastlandstidens Moser.

Paa et Par Steder i den ydre Del af Randers Fjord, hvor Kystlinjen ændrer Retning, er der aflejret Strandgrus som Strandvolde og Accumulationsterrasser, saaledes $\mathrm{S} \varnothing$ for Tørring, hvor den gamle Kyst drejer fra $\mathrm{N}-\mathrm{S}$ til $\mathrm{N} \varnothing-\mathrm{SV}$ ind mod Gjesinggaard. Udfor det derved fremkomne Hjørne er der opkastet en vinkelformet Strandvold, bestaaende af groft Grus og Flintgrus. Den usædvanlige Mængde Flint stammer fra Blegekridtet, der er faststaaende i Kystskrænten indenfor. Strandvoldens Højde er $5.3 \mathrm{~m}$, paa et kort Stykke $5.6 \mathrm{~m}$ o. H. $2 \mathrm{~km}$ Syd for Støvringgaard skifter den tidligere Kystlinje (og Randers Fjord) Retning fra $\mathrm{N}-\mathrm{S}$ til $\varnothing-\mathrm{V}$. Der er her bygget en bred Strandvold op fra Nord mod Syd. Sydligst breder Strandvolden sig og danner et stort Grusplateau med nødde- til ægstore Sten. Strandvoldens Ryg ligger 4.4-5.0 m o. H.; længst mod Nord ved Voldens Rod under Bakkeskrænten stiger Højden til $5.3 \mathrm{~m} \mathrm{o.} \mathrm{H.}$

Syd herfor, paa Fjordens Sydside, findes ved Uggelhuse og Vest derfor mindre Strandvolde og Erosionsterrasser, der naar til en Højde af $4.7 \mathrm{~m} \mathrm{o.} \mathrm{H.;} \mathrm{langs} \mathrm{Fjordens} \mathrm{øvrige} \mathrm{Kyster} \mathrm{ses} \mathrm{meget} \mathrm{lidt} \mathrm{til} \mathrm{Strand-}$ dannelser, og mindre og mindre, jo længere man kommer indad i den tidligere Fjord.

Hvor Randers Fjord har Retning Øst--Vest og nu kun er en smal Rende i de brede Enge, har Fjorden i Litorinatiden udfyldt hele Dalen og er naaet ind til de høje Bakker paa begge Sider. Dalens Bredde aftager jævnt ind mod Randers By, hvor den er mindre end $1 \mathrm{~km}$, for atter Vest derfor at udvide sig til den dobbelte eller tredobbelte Bredde. Byens Beliggenhed er derfor ikke tilfældig. Byen er ikke opstaaet ved Fjordens inderste Ende, idet denne i Oldtiden var en anden end i Middelalderen, og i Nutiden er et ret usikkert Begreb. Men Byen er lagt ved Fjordbredden, et godt Stykke indenfor Fjordens Munding, og paa det Sted, hvor Højdedragene fra Nord og Syd nærmer sig hinanden mest. Her har der lige fra Stenalderen, da hele Dalen var en Fjord, og senere ned i Tiden, da den gamle Fjordbund groede til og omdannedes til Kær og Sump, været det bedste Overfartsted. Her samledes Vejene stjærneformet fra Nord og Syd, og her var det naturlige Sted for en Bebyggelse allerede i Oldtiden, paa samme Maade som f. Eks. ved Aalborg, Varde og flere andre jyske Byer.

Ved Fladbro, ca. $5 \mathrm{~km}$ Vest for Randers, har den tidligere Fjord delt sig i to Grene, hvoraf den ene strakte sig mod SSV ind i Gudenaa Dalen, den anden mod Vest ind gennem Nørreaa Dalen.

Fra Fladbro har den tidligere Gudenaa-Fjord aftaget stærkt i 
Bredde Syd paa mod Langaa, og Øst for Langaa Station, hvor Engene endnu kun ligger ca. $2 \mathrm{~m}$ o. H., har Fjordens Bredde været knap $200 \mathrm{~m}$. Den betydelige Mængde Ferskvand, der fra Gudenaa stadig førtes ud gennem denne smalle Rende, har derfor i høj Grad kunnet hæmme Indvandringen af marine Dyreformer. En Boring lidt længere inde i Dalen, ved Jernbanebroen over Gudenaa Syd for Langaa Station, viste øverst $3 \mathrm{~m}$ marint Ler med ganske enkelte Skalfragmenter af Blaamusling, og derunder Sand. $300 \mathrm{~m}$ Syd for Jernbanebroen fandtes $5.8 \mathrm{~m}$ brunt og graat, dyndet Ler, i hvis nederste Del der saas enkelte Skalfragmenter af Cardium og Mytilus, derunder $1.6 \mathrm{~m}$ Tørv og nederst Sand og Grus. Engens Overflade ligger paa disse Punkter ca. $2 \mathrm{~m} \mathrm{o}$. H. Læengere ind i Dalene har de marine Aflejringer ikke kunnet følges, hverken langs Gudenaa eller Syd paa langs Lilleaa. Boringer i Gudenaa Dalen Sydvest for Langaa viste, at Dalens oprindelige Grusbund her ligger meget højt og har dannet en Tærskel, der i Forbindelse med Gudenaaens Vandmasse har kunnet holde det salte Vand ude.

Helt anderledes stiller Forholdene sig i Nørreaa Dalen, hvor marine, skalførende Lag kan følges ind $\bmod$ Vest indtil $3-4 \mathrm{~km}$ fra Viborg. I 1881 lod A. Feddersen udføre en Boring Syd eller Sydvest for Tapdrup, hvorved han i 10 Meters Dybde traf Skaller af marine Mollusker ${ }^{1}$ ). Ved de i 1908-1909 af Hedeselskabet foretagne Forundersøgelser i Anledning af Reguleringen af Nørreaa udførtes en Del Boringer, hvorved der jævnlig blev truffet marine Lag, lige fra Fladbo nær Randers og Vest paa indtil Vibæk Vandmølle ØSØ for Viborg $\left.{ }^{2}\right)$. Endelig har Forf. ved Boringer mellem Tapdrup og Rindsholm bestemt den tidligere Fjords inderste Grænse, der fandtes at ligge Sydøst for Bruunshaab Fabrik i Nærheden af Viborg.

Nørreaa Dalen har et meget ringe Fald ud ad mod Randers, og Dalbunden ligger meget lavt; paa Strækningen fra Fladbro op til Skjern Kirke ligger største Delen af Engen kun fra 1 til $3 \mathrm{mo}$. H. Under de øvre Ferskvandslag, Tørv, Gytje, Diatomékisel, m. m., ligger marint Ler og Dynd, der her er let tilgængeligt. Ved Skjern Kirke, $13 \mathrm{~km}$ fra Fladbro, indsnevres Dalen saa stærkt, at den tidligere Fjord kun har haft en Bredde af $2-300 \mathrm{~m}$. Nordvest og Vest derfor danner Dalen en meget stor Bredning, i hvilken den langstrakte, $52 \mathrm{~m}$ høje Banke, Ø, ligger. Denne Banke har i Stenalderen ligget som en $\varnothing \mathrm{i}$ den gamle Fjord, og senere - da Bredningen

1) Offentliggjort i 1886 af Ed. Eeslev i hans Bog: Jylland. Studier og Skildringer til Danmarks Geografi. Kjøbenhavn. 1886. Side 63.

$\left.{ }^{2}\right)$ Offentliggjort af A. Mentz i: Beskrivelse af Nørre Aa Dalens Moser og Enge. Udgivet af Det danske Hedeselskab. Viborg 1910. 
omdannedes til en Ferskvandssø og endnu senere til fugtige Kær som en Holm, til hvilken der kun var Adgang Vest fra, fra Viskum Kirke.

I Engene Nord for $\varnothing$ er de marine, skalførende Aflejringer paaviste ved de af Hedeselskabet foretagne Boringer. Den fundne Fauna er dog meget fattig, vistnok en Følge af, at Fjordens Hovedløb har gaaet Syd for Øby, hvor der er langt dybere ned til den faste Sandbund. Denne naaedes ved Nybro mellem Viskum og Øby først i en Dybde af $9.8 \mathrm{~m}$. Videre mod Vest bliver Dalen atter smallere; Fjorden har haft en Bredde af ca. $600 \mathrm{~m}$, men har til Gengæld været temmelig dyb. Ved Hedeselskabets Boring ved Vejrum Bro, hvor Engens Overflade ligger ca. $4 \mathrm{~m}$ o. H., havde man i en Dybde af $12 \mathrm{~m}$ endnu ikke naaet fast Bund.

Endnu længere Vest paa, ved den af Feddersen udførte Boring i Skovsgaard Enge, S eller SV for Tapdrup, fandtes følgende Lagserie:

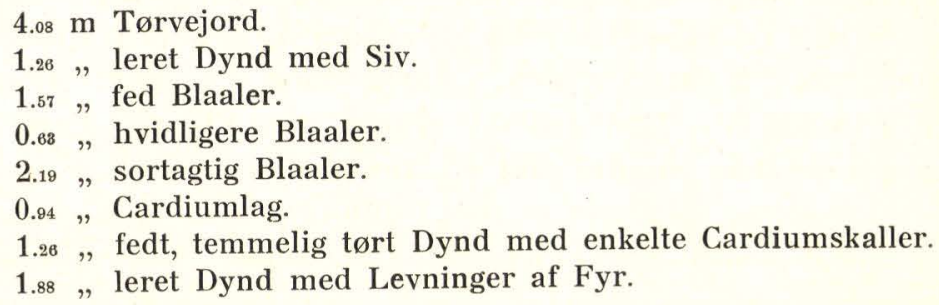

Engens Overflade ligger her $4-5 \mathrm{~m}$ o. H. Hvad der fandtes under det nederste Dynd med Fyrrelevninger, omtales ikke, men sandsynligvis har det været den faste Sandbund, da der gives et saa nøjagtigt Maal for Dyndlagets Tykkelse. De ved Boringen fundne Mollusker var følgende: Cardium edule, Mytilus edulis, Litorina litorea, Nassa reticulata, Lacuna sp., Cerithium sp., Neritina fluviatilis. At Arter som Cerithium og Nassa reticulata, der dog fordrer en ret betydelig Saltholdighed $(15-16 \%$, har kunnet leve saa langt inde i denne smalle Fjord, er ejendommeligt. Forklaringen maa søges dels i den større Saltholdighed i Kattegat i Litorinatiden, dels i, at der ind gennem denne Fjord maa have ført en dyb Rende, hvad enkelte af Boringerne ogsaa viser, og saaledes som det kendes fra flere af vore nuværende Fjorde. Gennem denne Rende, er det salte, tunge Havvand trængt ind som en Bundstrøm, medens det ferske Aavand er flydt ud i Overfladen.

For nøjagtigt at afgøre, hvor langt Fjorden og det salte Vand er naaet ind i Nørreaa Dalen, udførtes der nogle Boringer i Engene mellem Tapdrup og Rindsholm. Det inderste Punkt i Dalen, hvor Fjordaflejringer med marine Molluskskaller kunde paavises, var ved Vejen, der gaar tværs over Engen mellem Randrup og Bruuns- 
haab Fabrik. Som to smalle Vige, adskilte ved en flad Sandbanke, er Fjorden naaet ind hertil. I den østlige Rende nærmest Randrup Bro fandtes $3.8 \mathrm{~m}$ Tørv, derunder $0.2 \mathrm{~m}$ fedt, graat, marint Ler med smaa Stykker af Mytilus, og derunder Grus. I den vestlige Rende viste en Boring øverst 6.3 $\mathrm{m}$ Tørv, derunder $0.3 \mathrm{~m}$ sort Dynd, derunder $0.3 \mathrm{~m}$ graat, dyndet Ler med enkelte Skalfragmenter af Cardium og Mytilus, og nederst Sand. Syd for disse Punkter, ind mod Rindsholm og Viborg Søerne, fandtes der udelukkende Ferskvandsaflejringer.

Den lange, smalle Fjord, der i den ældre Stenalder, under Litorina-Sænkningens Maksimum, strakte sig helt ind til Hjærtet af Nørrejylland, var uden Sidestykke her i Landet. Alene Fjordarmen gennem Nørreaa Dalen fra Fladbo til Randrup har haft en Længde af $35 \mathrm{~km}$. Til Sammenligning kan nævnes, at den Fjord, der, som beskrevet Side 76, strakte sig fra Aalborg Syd paa forbi Svenstrup og Skjørping til Gravlev Sø, kun havde en Længde af $26-27 \mathrm{~km}$. Man maa søge til det sydligste Slesvig, til Slien, for at finde en Nutidsfjord, der saavel i Læengde som i Bredde og Omgivelser kan minde om Nørreaa Fjorden. Maales hele den gamle Randers Fjord, fra Udbyhøj til dens inderste Ende nær Viborg, naar man til en Længde af ikke mindre end $65 \mathrm{~km}$.

Ikke alene mod Nord ved Udbyhøj, men ogsaa mod Øst stod Randers Fjord i Forbindelse med Kattegat. Den smalle, nu halvt tilgroede Fjordarm, Grund Fjord, der Øst for Randers strækker sig Øst paa ud mod Ørsted, er den sidste Rest af et bredt Sund, der har kunnet følges videre mellem Ørsted og Vivild ud til Kattegats Kyst ved Hevring. Allerede ret tidlig under Landhævningen maa dog dette Sunds østlige Udløb være bleven lukket eller i alt Fald stærkt indsnevret ved et stort System af Strandvolde, der aflejredes tværs over Fjordmundingen mellem Hevringholm og Hevring By. Strømmen har her baade fra Nordvest og fra Øst ført Sand og Grus hen imod Sundets Munding og har opbygget Strandvolde, der fra Nordvest løber omtrent parallele med den gamle Kattegatskyst, medens de Øst fra kommende spreder sig vifteformet og bøjer mod Sydvest ind mod Hevring By. Strandvoldene mellem Estruplund og Hevring naar, som nævnt Side 81, til en Højde af $6-6.5$ m o. H.; de østfra kommende Strandvolde er noget lavere og ligesom de første delvis dækkede af Flyvesand.

Foruden Sundet ved Hevring fandtes der i Stenalderhavets Tid endnu et Sund, gennem hvilket Randers Fjord stod i Forbindelse med Kattegat, nemlig det lange, snevre Sund, der fra Grund Fjord og Allingaabro er fulgt først mod Syd forbi Gl. Estrup og derefter mod Sydøst forbi Pindstrup Station og Ryomgaard til Ko- 
lindsund. Eksistensen af dette Sund, der findes anført paa alle tidligere Kort over Overfladedannelserne i Danmark, og som i Reglen omtales som en Kendsgærning, er vistnok aldrig tidligere bleven paavist. Man er rimeligvis lige fra Forchнамmers Tid gaaet ud fra, at Kolindsund i Følge sit Navn maatte have været ikke blot en Fjord, men et Sund, og man har da tegnet dette Sund gennem Engdragene mellem Ryomgaard, Gammel Estrup og Randers Fjord, til Trods for, at Overfladen af Engene inde ved Pindstrup Station ligger ikke mindre end $9 \mathrm{~m}$ o. H., altsaa langt højere end postglaciale, marine Lag vil kunne træffes i denne Egn.

Gammel Estrup-Ryomgaard Sundet følges let fra Allingaabro ved Grund Fjord Syd paa forbi Gl. Estrup, idet de skalførende, marine Lag ses tæt under Overfladen i den kun 1-2 m o. H. liggende Engstrækning. Syd for Gl. Estrup har der strakt sig en Vig mod Vest hen imod Virring og op langs Allingaa. Ude i det store Kær mellem Øster Alling og Virring, hvor Overfladen kun ligger $2^{1 / 2}-3^{1 / 2} \mathrm{~m}$ o. H., findes marint Ler og Dynd dækket af Tørv med vekslende Mægtighed. Mod Sydvest opad Allingaa har Fjorden næppe strakt sig ret langt; allerede ved Skjelbro, SV for Vester Alling, ligger den faste Sandbund nede i Engen ca. $3 \mathrm{~m} \mathrm{o.} \mathrm{H.,} \mathrm{og} \mathrm{i} \mathrm{den} \mathrm{store} \mathrm{Mose-}$ strækning Vest herfor ved Klausholm har man ved Boringerne ikke kunnet finde marine Skaller i det under Tørvelaget liggende, fede, dyndede Ler, som derfor efter al Rimelighed er Ferskvandsler.

Fra Gl. Estrup kan det tidligere Sund følges videre mod Sydøst ind forbi Pindstrup Station. Engens Overflade stiger dog paa denne Strækning fra 2 til $9 \mathrm{~m}$ over Havet, og da Lavningen flere Steder er stærkt indsnævret, syntes Forekomsten af et Sund her igennem at være noget usandsynlig. Ved et stort Antal Boringer, der er udført her, er det dog lykkedes at følge marine Aflejringer gennem hele denne Strækning, men ganske vist som en meget smal Rende og under et Tørvelag paa indtil 10 Meters Tykkelse.

Størst Interesse knytter der sig til det smalle og højtliggende Engdrag ved Pindstrup Station. I Smørmose NV for Stationen (Overfladen ca. $8 \mathrm{~m}$ o. H.) fandtes i Mosens sydvestlige Del indtil $5 \mathrm{~m}$ Tørv over dyndblandet Sand, og i den nordøstlige Del en dybere Rende i Sandbunden, hvor der under $7-7^{1 / 2} \mathrm{~m}$ Tørv fandtes ca. $1 \mathrm{~m}$ marint Dynd med Skaller af Cardium og Mytilus. Hvor Vejen gaar over Mosen ved Pindstrup Station, ligger den glaciofluviale Sandbund næsten overalt langt over den Højde, hvortil marine Aflejringer vil kunne findes her. Kun nærmest Jernbanelinjen fandtes ved Boringerne en ganske smal, ikke $100 \mathrm{~m}$ bred Rende med stejle Sider, hvor der under 9.5-10.0 m Tørv laa $0.7 \mathrm{~m}$ mørkt Dynd med Skaller af Cardium, og derunder Sand uden Skaller. Endnu paa en kort Stræk- 
ning holder den dybe Rende sig i Mosens nordlige Del nærmest Jernbanelinjen, men derefter bliver Sundet bredere, jo længere man kommer mod Øst. Samtidig synes det, som om Faunaen i de marine Lag, Dynd, Ler og enkelte Steder Sand, bliver rigere baade paa Arter og Individer.

Fra Hovedsundet er en lille Vig naaet Syd paa ind mod Skafø Gaard, uden dog at naa helt ind til Gaarden, og noget østligere har et stærkt forgrenet Fjordsystem strakt sig langt ind mellem Bakkedragene mod Syd. To Fjorde, én fra Tjerrild Syd for Marie Magdalene Kirke, og én fra Ballegaard Syd for Koed, førte Syd paa som smalle, bugtede Løb og forenedes i en større Bredning mellem Thorsager og Ebdrup; herfra strakte Fjorden sig videre mod Sydøst ind til Korupsø, $3 \mathrm{~km} \varnothing \mathrm{N} \varnothing$ for Kalø. Til Trods for, at denne Fjord, Korup Fjorden, udgik fra den indre Del af Kolind-Randers Sundet og havde et baade bugtet og snevert Løb, er Faunaen i de marine Lag dog forbavsende rig, i alt Fald paa Individer, selv i Fjordens inderste Vige. Bundforholdene viser desuden, at der, hvor Fjorden har været smal, som f. Eks. Nord og Øst for Thorsager, maa have løbet en temmelig stærk Strøm. I Engen $1 \mathrm{~km} \mathrm{N \varnothing}$ for Thorsager, hvor Overfladen ligger $8 \mathrm{~m} \mathrm{o}$. H., findes saaledes $5 \mathrm{~m}$ Tørv og derunder groft Sand med en Mængde Molluskskaller. Ved Skummelvad Bro, $1.7 \mathrm{~km} \varnothing$ for Thorsager, findes $3.1 \mathrm{~m}$ Tørv over Strandsand med Skaller. Engens Overflade ligger her $6.6 \mathrm{~m} \mathrm{o}$. H. Sydvest derfor, hvor Fjorden har været bredere, findes marint, skalførende Ler under Tørven. Ved Saxvad Bro, $2^{1} / 2 \mathrm{~km} \varnothing$ for Thorsager, hvor Fjorden ligesom ved Skummelvad Bro har været meget smal, findes $3.4 \mathrm{~m}$ Tørv over Strandsand med mange Skaller; Engens Overflade ligger her $5.3 \mathrm{~m} \mathrm{o.} \mathrm{H}$. Sydvest for Ebdrup har Fjorden som næunt dannet en stor Bredning, i hvis smalle Sydende ved Rostvad Bro en Boring viste $2.2 \mathrm{~m}$ Tørv, derunder $2.2 \mathrm{~m}$ Sand saa tæt pakket med Skaller, at det maa kaldes en Skalbanke, og derunder groft Sand; Engens Overflade ligger paa dette Sted $4.4 \mathrm{~m} \mathrm{o.} \mathrm{H.}$ Et snevert Sund førte herfra ind til Fjordens sydligste Bredning, der udfyldte den store Lavning, i hvilken den nu udtørrede Korup Sø laa. Midt ude i den tidligere Bredning fandtes ved en Boring $2.5 \mathrm{~m}$ Ferskvandsdynd og derunder mere end $9^{1 / 2} \mathrm{~m}$ marint Dynd med talrige Skaller af Cardium edule. Langs Bredningens nordøstlige Kyst findes skalholdigt Strandsand, opkastet som en flad Strandvold, der ligger noget over $5 \mathrm{~m} \mathrm{o.} \mathrm{H.}$

Fjordens østlige Gren fra Koed Syd paa mellem Skarresø og Ebdrup har været temmelig smal, men meget dyb, og har utvivlsomt været Hovedløbet for det salte Vand, der naaede helt ind i Korup Bredningen. At Saltholdigheden ude i Hovedsundet maa have 
været temmelig stor, og at der har levet en rig Fauna, derom vidner Dyreresterne i de ved Koed og ved Kolind forekommende, nu delvis bortgravede Affaldsdynger fra den ældre Stenalder.

Ved Kolind munder Hovedsundet ud i det egentlige Kolindsund, der indtil for nylig var en stor Indsø, Dyrsø eller Djursø, henved en Snes Kilometer lang og med et Areal af $4000 \mathrm{Tdr}$. Land (2200 ha). Søen udtørredes i Aarene 1874-1883; det derved indvundne Areal bestaar overvejende af marint Ler og Dynd, i Reglen dækket af et Lag Ferskvandsdynd med meget vekslende Mægtighed. Boringer ude i det tørlagte Areal har vist, at det marine Ler- og Dyndlag kan have en Tykkelse paa $16 \mathrm{~m}$ eller mere. I Stenalderen stod Kolindsund i aaben Forbindelse med Kattegat; Fjordmundingen havde meget stor Bredde, idet den udstrakte, nu af Flyvesand delvis dækkede Hedestrækning mellem Grenaa, Hessel og Kysten var dækket af Havet. Den marine Fauna i Kolindsund var derfor overordentlig rig, blandt andet fandtes der betydelige Østersbanker; Sundets Kyster maa have været et søgt Opholdssted for Stenalderfolket, idet der rundt omkring er fundet Affaldsdynger, saavel fra den ældre som fra den yngre Stenalder.

Kysterne langs det tidligere Sund staar paa mange Steder som høje, stejle Brinker, hvad der dog ikke skyldes marin Erosion, men Smeltevandsflodernes Virksomhed under Indlandsisens Bortsmelten fra denne Egn. Saavel mod Nord som mod Syd har smalle Sidefjorde strakt sig ind i Landet. Nord for Kolind naaede en lille Fjord et Stykke ind gennem Dalen hen imod Nimtofte; den i Fjordmundingen liggende Banke, paa hvilken nu Gaarden. Vedø er bygget, var en $\varnothing$. Østligere, ved Fannerup, strakte en Fjord sig et Stykke ind gennem den smalle Dal langs Ørum Aa. Ved Mundingen af denne lille Fjord er der fundet ikke mindre end 6 større Affaldsdynger fra Stenalderen; blandt disse er den mest bekendte og bedst undersøgte en paa Fjordens Østside mellem Fannerup By og Fannerup Gaard liggende Affaldsdynge fra den yngre Stenalder. Den høje Banke Vest for Fannerup By var under Litorina-Sænkningens Maksimum en $\varnothing$, adskilt fra Landet Vest derfor ved et smalt Sund, der dog allerede lukkedes meget tidligt under Landets Hævning. Ved Enslev, $4 \mathrm{~km}$ Vest for Grenaa, strakte en temmelig bred Fjord sig $\mathrm{i}$ en Bue ind i Landet mod Nord og Vest. Fjorden har i alt Fald naaet ind til Partiet mellem Holmegaard og Sleminge Gaard. En Boring længere inde i Dalen, i Ginnerup Kær ØNØ for Holmegaard, hvor Overfladen laa $7.2 \mathrm{~m} \mathrm{o}$. H., viste $2.5 \mathrm{~m}$ Tørv, derunder $0.6 \mathrm{~m}$ Ferskvandsdynd og -kalk med Ferskvandsmollusker, og nederst groft, graat Sand. Om dette Sand er marint, lod sig ikke afgøre, men det er næppe sandsynligt. 
Det er saaledes nu lykkedes at følge de marine Lag fra Randers Fjord forbi Ryomgaard til Grenaa. Den faste Sandbund ligger paa det højeste Sted, ved Pindstrup Station, ca. 1 m under Havets Niveau og har under Litorina-Sænkningens Maksimum ligger 3-4 m lavere. Det er derfor sandsynligt, at der den Gang har løbet en stærk Strøm gennem Sundet, afhængig af Tidevand og Vindretning $\mathrm{i}$ Randers Fjord og Kolindsund. Senere, under Landhævningen, maa Strømmen være blevet hæmmet, idet der paa det smalleste Sted i Sundet er aflejret Ler og. Dynd med en efter Boreprøverne at dømme meget fattig Fauna. Boringerne synes endvidere at vise, at den marine Fauna aftager i Rigdom baade paa Arter og Individer, jo nærmere man saavel fra Randers Fjord som fra Kolindsund nærmer sig Snevringen ved Pindstrup.

Nordkysten af Djursland havde i Stenalderhavets Tid en mere bugtet og fliget Kystlinje end i Nutiden. Side 85 omtaltes det brede Sund, der mellem Hevringholm og Hevring By strakt sig mod Syd og Vest forbi Ørsted til Grund Fjord og Randers Fjord. Udenfor den gamle Kystlinje er der her ved Samvirken mellem Kyststrømmens Materialtransport og Landets Hævning dannet en bred Bræmme af nyt Land. Ostligere, ved Fjellerup og Mejlgaard, har en bred Bugt, i hvilken der laa flere Holme, naaet $2-3 \mathrm{~km}$ ind i Landet. Ud mod Kattegat findes anselige Strandvolde, aabenbart dannede efter Litorina-Sænkningens Maksimum, paa et Tidspunkt da Landet allerede var hævet noget. Saaledes ses Nord for Fjellerup yderst en Nutidsstrandvold, der naar til $1.6 \mathrm{~m}$ o. H., indenfor den en flad, græsklædt Strandvold $2.5 \mathrm{~m}$, og inderst en rygformet, stenet Strandvold $5.0 \mathrm{~m}$ o. H. En Del af de gamle Havstokke herude er nu dækkede af Flyvesand. I den Bugt, der naaede ind mod Mejlgaard, og som delvis afspærredes fra Kattegat ved tre Holme, levede en meget rig Molluskfauna, hvis Skaller nu findes i det sandede Ler, der aflejredes i Bugten. Paa Nordsiden af Halvøen Ejgholm i Nederskov ligger, $6-7 \mathrm{~m}$ o. H., den bekendte, store Affaldsdynge fra den æeldre Stenalder.

Langs Treaa, mellem Mejlgaard og Hemmed, har en temmelig stor Bugt strakt sig $3-4 \mathrm{~km}$ Syd paa ind i Landet. Ogsaa omkring Gjerrild er der siden Stenalderhavets Tid sket meget betydelige Forandringer i Kystlinjens Beliggenhed; fra det fremspringende Parti ved Stavnshoved, N for Emmedsbo, hvor den gamle Kyst endnu staar som en høj, stejl Skrænt, løb Kystlinjen mod Sydøst og bøjede derfra i en ret Vinkel ud mod Nordøst til Nordenden af Gjerrild Klint. Inde $\mathrm{i}$ den derved fremkomne Bugt ses ingen Stranddannelser, idet den var delvis afspærret fra Kattegat ved nogle større og mindre 
Holme samt af de indtil $7^{\circ} \mathrm{m}$ høje Strandvolde, der fra Stavnshoved voksede ud mod Øst, over mod de nævnte Holme. I en lav Strandbrink Øst for Gjerrild findes et Profil gennem Bundlagene i en lille tidligere Vig. Der ses her skalførende Dynd indtil $1.7 \mathrm{~m}$ o. H., derover $0.8 \mathrm{~m}$ sandet Dynd og øverst skalførende Strandsand, der naar til en Højde af $4^{1 / 2} \mathrm{~m}$ o. H.

Syd for Gjerrild har en Fjord sendt en bred Arm ind mod Benzon uden dog at have naaet helt ind til det Sted, hvor Gaarden er bygget, eller ind i Gjerrild Sø; den glaciale Sandbund i Engen ved Benzon ligger nemlig i større Højde end den, hvortil marine Aflejringer vil kunne findes her. En anden Arm af Fjorden har strakt sig mod Sydvest ind gennem Dalen mellem Veggerslev og Rimsø. Ved Veggerslev Bro nedenfor Veggerslev By ses i Aabrinken sandet, marint Dynd med store Mængder af Skaller, fortrinsvis af Cardium edule, til en Højde af $4.4 \mathrm{~m}$ o. H. Fjordlagene er herfra ved Boring fulgt endnu et Par Kilometer mod Sydvest ind gennem den store, senglaciale Dal, men har ikke naaet saa langt som til Emmelevvase Bro, hvor Sandbunden i Dalen ligger for højt (over $6 \mathrm{~m} \mathrm{o.} \mathrm{H.).}$

En smal Vig er naaet et lille Stykke ind i den Lavning, der fra Karlby Klint kan følges mod Syd forbi Sangstrup og Hammelev til Grenaa; endvidere synes det, som om den Lavning, der, parallelt med den nylig omtalte, afskærer Stensmark-Fornæs Partiet fra det øvrige Land, i en kortvarig Periode under Landsænkningens Maksimum har været et Sund, der mod Syd har delt sig i to Grene, hvoraf den ene har ført mod Sydøst langs Saltbæk ud til Kattegat, den anden mod Sydvest til Lavlandet ved Grenaa. Ganske vist er der ikke ved Boringerne i det lerede Sand, der udfylder den midterste og højeste Del af Lavningen, fundet marine Dyrerester, men den Højde, hvortil dette Sand findes, tyder paa, at Havet netop under Sænkningens Maksimum har kunnet trænge herind.

Den diluviale Banke, hvorpaa Stensmark og Fornæs Fyr ligger, har gennem hele Litorinatiden været stærkt udsat for Kattegats Angreb; medens Erosionen er mest fremherskende paa Strækningen fra Fornæs til Grenaa, er der paa andre Steder, i Særdeleshed mod Nord, aflejret Strandvolde til meget betydelig Højde. Ved Mundingen af Stensmark Bæk, $2 \mathrm{~km} \mathrm{NV}$ for Fornæs Fyr, ses nærmest Stranden en vegetationsløs Nutidsharstok $2.5 \mathrm{~m}$ o. H., og bagved den en lyngdækket Strandvold, hvis Højde er $5.6 \mathrm{~m}$, mod Syd $6.3 \mathrm{~m} \mathrm{o.} \mathrm{H.}$ Paa Pynten Sydøst derfor findes yderst en Nutidsstrandvold $2.5 \mathrm{~m}$, derefter en flad, græsdækket Strandvold $3.8 \mathrm{~m}$, inderst en voldlignende, lyngdækket Strandvold $6.0-6.2 \mathrm{~m} \mathrm{o}$. H., og ovenfor denne Vold kan flade Strandsten følges op paa Marken til en Højde af 7.2 m o. H. Paa Nordsiden af den næste Pynt, NNØ for Stensmark, 
ses oven over Nutidshavstokken og svarende til den ovennævnte, græsdækkede Strandvold, en Erosionsterrasse $4 \mathrm{~m}$ o. H. Paa Pyntens Sydside findes en Erosionsterrasse ca. $5 \mathrm{~m}$ o. H. $200 \mathrm{~m}$ Syd for Pynten ses en lyngdækket Strandvold 5.6-6.0 $\mathrm{m}$ o. H., og indenfor denne en Erosionsterrasse, der er noget ødelagt ved Sandflugt, men iøvrigt meget tydelig, og hvis Højde er $7.5 \mathrm{~m}$ o. H. I Fortsættelse af dette Terrassehak kan der mod Sydøst ud mod Fornæs Fyr følges en Strandvold af omtrent samme Højde; paa Fyrbankens Nordside har den yderste, recente Strandvold en Højde af $2.5 \mathrm{~m}$, enkelte Steder lidt mere; indenfor den ses flere Strandvolde, hvoraf den mest udprægede naar til $5.6 \mathrm{~m}$ o. H., og inderst en bred, svagt rygformet Strandvold af flade, haandstore Strandsten $7.5 \mathrm{~m} \mathrm{o}$. H. Mod Sydøst hen imod Fyret kan denne Strandvold følges som en Belægning af flade Strandsten over den diluviale Banke til en Højde af $7.8 \mathrm{~m}$ o. H. (mod Sydøst er denne Strandvold paa Generalstabens Kort, $1: 20.000$, angivet ved den nordøstlige Del af en 25 Fods Kurve $)^{1}$ ). Paa Sydsiden af Fyrbanken, tværs over Lavningen mellem Fyret og Stensmark, ligger en flad Strandvold, hvis Højde er $6 \frac{1}{2}$ $\mathrm{m}$ o. $\mathrm{H}$.

Fra Fornæs mod Syd til Grenaa Kalkbrud staar den gamle Kyst som en temmelig høj og stejl Skrænt; paa flere Strækninger har Flyvesandet dækket Skræntens Fod, paa andre Steder er denne udækket, og der ses da en smal Accumulationsterrasse langs Bakkefoden. Dette er f. Eks. Tilfældet, hvor Vejen fra Hammelev naar ned til Stranden; de æg- og haandstore, rullede Strandsten naar her til en Højde af $7.2-7.5 \mathrm{~m}$ o. $\mathrm{H}$.

Da man kan gaa ud fra, at Kattegat lige saa vel i Stenalderen som i Nutiden har kunnet kaste Strandsten op til en Højde af 2.5--2.8 $m$ paa denne Del af Kysten, viser de ovenfor angivne Højder paa Stenalderhavets Havstokke (indtil $7.8 \mathrm{~m}$ o. H.), at Landhævningen siden Litorina-Sænkningens Maksimum paa dette Punkt maa have været omtrent $5 \mathrm{~m}$.

Sydsiden af Indløbet til Kolindsund tegner sig ikke saa skarpt i Terrainet som Nordsiden, idet Flyvesand har dækket den tidligere Kystlinje. Først noget sydligere træder den gamle Kyst frem som en næsten ret Linje, den kan følges Syd paa forbi Katholm til Katholm Skov. Foran Kysten har der ligget et Par Øer, de nuværende Banker Annebjerg og Havknude, hvis Østsider ud mod Kattegat staar som stejle Kystklinter, medens Vestsiderne er jævnt skraanende ned mod det tidligere Sund mellem Øerne og Fastlandet.

1) I \Danmarks Geologi", D. G. U. III. Række, Nr. 2, 2den Udgave 1904, angiver Ussing Højden af Strandvoldene ved Grenaa til 23 Fod $(7.2 \mathrm{~m})$ og i 3die Udg. 1913 ved Poul Harder angives Højden til sgodt $7 \mathrm{~m}$ *. 
Længere mod Syd, ved Rugaard, har Landet tidligere været mere indskaaret. En Fjord har strakt sig et Stykke ind gennem den dybe, senglaciale Dal ved Hoed, og Bugter har skaaret sig ind baade Nord og Syd for Rugaard. Under Landhævningen har brede Strandvolde forbundet Kystens fremspringende Punkter mod Nord og Syd og har omdannet Fjord og Bugter til en Lagune, hvis sidste Rest er Nørresø ved Rugaard. Saavel Nutidsstrandvoldene som de ældre Strandvolde fra Stenalderhavets Tid har en betydelig Højde. Øst for Rugaard, hvor Havet er dybt tæt ind til Kysten, og Bølgeslaget meget stærkt, ligger saaledes den vegetationsløse Nutidsstrandvold 2.5-2.8 m o. H., og Strandgruset i den højeste af de indenfor liggende, gamle Strandvolde naar til $6.9 \mathrm{~m}$ o. $\mathrm{H}$.

Endnu sydligere har saavel den anselige Stubbe Sø, hvis Vandspejl nu kun ligger $1 \mathrm{~m}$ o. H., som Draaby Sø staaet i Forbindelse med Kattegat ved bugtede og forgrenede Sunde. De marine, skalførende Ler- og Dyndlag inde i disse Vige og Sunde er næsten overalt dækkede af Tørvedannelse og ses kun, hvor Vandløbene har skaaret sig ned gennem de øvre Lag; derimod staar de gamle Kystlinjer ret tydelige paa adskillige Steder. Ud mod Kattegat afspærres Lavningerne ved Strandvolde, der inde ved Højlandet, hvorfra de udgaar, kan have en Højde af $5-5.5 \mathrm{~m} \mathrm{o}$. H. En meget stor og smukt formet Strandvold, hvis Ryg ligger $5.6 \mathrm{~m} \mathrm{o}$. H., udgaar fra Jernhatten mod Nord og afspærrer en lille Vig, der har naaet ind imod Skovgaarde.

Ebeltoft Halvøen har under Litorina-Sænkningens Maksimum været forbundet med Fastlandet ved en kun $1^{1 / 2} \mathrm{~km}$ bred Hals, idet der ØNØ for Ebeltoft strakte sig en bred Bugt ind i Landet indtil Nordvest for Boslum. Foran denne Bugt er der senere opkastet store, brede Strandvolde, der naar til en Højde af $5.7 \mathrm{~m} \mathrm{o.} \mathrm{H.}{ }^{1}$ ). Det store Sletteland paa Halvøens Sydspids ved Hasenøre er nydannet Land; det bestaar af et lavt Midtparti, den omkring 1850 udtørrede Vestensø, der kun ligger $1 \mathrm{~m} \mathrm{o}$. H., og som omgives af højere Strandvolde, der angiver Landets gradvise Vækst under Litorina-Hævningen. Strandvoldenes Højde er mod Nordøst, hvor de udgaar fra Højlandet, $4.9 \mathrm{~m}$., sydligere ved »Ranes Ladegaard $44.8 \mathrm{~m}$ og ved Landets Sydspids $4.6 \mathrm{~m}$ o. H.

Øen Hjelm bestaar af en lille, $41 \mathrm{~m}$ høj Banke, der paa alle Sider staar med stejle Brinker, tydelige Vidnesbyrd om Havets Erosion. Uden om denne Kærne, i Særdeleshed mod Nordøst og Syd-

1) Maalingen ved Boslum samt de nedenfor anførte Maalinger paa Hjelm, ved Ebeltoft og paa Helgenæs er udforte i 1892 sammen med Statsgeolog Dr. Victor Madsen. Se desuden: Victor Madsen. 1897. Kortbladet Samsø. D. G. U. I. Række, Nr. 5. 
vest, findes et bredt Bxlte af stenede Havstokke, aflejrede under Landets Hævning, efter at Erosionen var ophørt. Paa Øens Sydside har disse Strandvolde en Højde af indtil $5.3 \mathrm{~m}$, og paa Vestsiden af $4.4 \mathrm{~m} \mathrm{o.} \mathrm{H.;} \mathrm{en} \mathrm{Erosionsterrasse} \mathrm{i} \mathrm{Bakkefoden} \mathrm{ligger} \mathrm{her} 4.5 \mathrm{~m} \mathrm{o.} \mathrm{H}$. Nutidsstrandvoldene har paa Hjelm en Højde af indtil $2.4 \mathrm{~m}$.

Inde i Ebeltoft Vig, hvor Bølgeslaget er ringe, og hvor Nutidsstrandvoldene kun naar til $1-1 \frac{1}{2} \mathrm{~m}$ o. H., ligger ogsaa Litorinatidens Havstokke noget lavere end ude ved Kattegats Kyst. Ved Tollykke Skov SSV for Ebeltoft maaltes dog Strandgrus til en Højde af $4.9 \mathrm{~m}$ o. H. Hævede Strandvolde ses desuden Nord for Ebeltoft og inderst i Vigen Syd for Lyngsbæk Gaard. Paa sidstnævnte Sted findes et lille System af lyngdækkede, stenede Strandvolde, delvis overføgne med Flyvesand. Strandstenene i den højeste Vold kan følges til $4.3 \mathrm{~m} \mathrm{o}$. H. Sydvest herfor findes mellem Femmøller og Bogens et temmelig lavtliggende Forland foran Bakkerne, en tidligere Bugt, der nu er tørlagt.

Helgenæs har i det store og hele samme Kystform nu som i Stenalderhavets Tid. Noget Land er utvivlsomt skyllet bort baade paa Øst- og Vestkysten, men til Gengæld er der andre Steder en Tilvækst af Land, saaledes mod Nordvest og i Særdeleshed mod Nordøst ved Vængesø. Her har Strandvolde, hvis Rygge nu ligger indtil $3.9 \mathrm{~m} \mathrm{o}$. H. omsluttet et lavere Parti, hvis centrale Del, Væengesø, senere er bleven udtørret ved Kunst. Tæt Syd herfor findes Strandgrus til en Højde af $4.3 \mathrm{~m} \mathrm{o}$. H.; egentlige Strandvolde fra Stenalderhavets Tid er sjældne paa Østkysten, hvor Erosionen har været overvejende. Paa Vestkysten af Helgenæs er hævede Havstokke og Strandlinjer bevarede paa flere Steder, saaledes mod Syd ved Sletterhage, hvor Strandvoldene naar til $3.8 \mathrm{~m}$, og omtrent 2 $\mathrm{km}$ nordligere, hvor Strandvolde naar til $4.3 \mathrm{~m} \mathrm{og}$ en Erosionsterrasse til $5.2 \mathrm{~m}$ o. H. Paa Nordvest- og Nordkysten findes NV for Helgenæs Kirke Strandgrus indtil $4.6 \mathrm{~m}$ o. H. og ved Landingsstedet NV for Kirken Strandvolde til $4.3 \mathrm{~m}$ o. H. I Nutiden er Helgenæs forbundet med Mols ved en smal Tange, der paa et enkelt Sted, ved Dragsmur, kun har en Højde af lidt over $3 \mathrm{~m}$. Mulig er denne Tange dog i Tidens Løb blevet noget forandret dels ved Vejanlæg dels ved Befæstningsanlæg saavel i Middelalderen som i nyere Tid. Ved Landsænkningens Maksimum har der her været et næppe Hundrede Meter bredt Sund, saaledes at Helgenæs var en $\varnothing$; under Landhævningen er Tangen, en almindelig Strandvold, bleven dannet af Strøm og Bølgeslag.

Langs Nordsiden af Begtrup Vig ligger Stenalderhavets Kystlinje $2-500 \mathrm{~m}$ indenfor den nuværende Kyst. Strandvolde findes her, $\mathrm{S} \varnothing$ for Tred, til en Højde af noget over $4 \mathrm{~m}$ o. H. Ogsaa Vestky- 
sten af Mols har faaet en anden Kystform. I Stenalderhavets Tid var den høje, isolerede Banke, Skjødshoved, en $\varnothing$, der under Landhævningen blev forbundet med Fastlandet ved store, fra Sydøst udgaaende Strandvolde, hvis Rygge nu ligger indtil $4 \mathrm{~m} \mathrm{o}$. H. Paa Nordsiden og i Læ af disse Strandvolde er store Arealer sandede til og tørlagte under Landhævningen. Senere er paa Nordsiden af Mols to lignende, tidligere Øer, Dejgret Øhoved og Tved Øhoved, blevet forbundne med Fastlandet ved lavtliggende Strandenge.

Inde i Knebel Vig, hvor Bølgeslaget er ringe, og Nutidshavstokken kun naar til $1 \mathrm{~m}$ o. H., er hævede Stranddannelser sjældne og svagt udviklede. Syd for Knebel har Vigen strakt sig noget længere ind $\mathrm{i}$ Landet mod $\varnothing_{\text {st, }}$ og en Erosionsterrasse ses her i en Højde af $3.1 \mathrm{~m}$ o. H. Nord derfor, $\mathrm{S} \varnothing$ for Rolsø Gaard, naar en Grusstrandvold til $2.5 \mathrm{~m} \mathrm{o}$. $\mathrm{H}$.

Inde i Kalø Vig er der ikke sket store Forandringer i Kystlinjens Beliggenhed. Kalø Slotsbanke har været en lille $\varnothing$, og en Fjord med et smalt Indløb har naaet ind i det nuværende Kokjær, SØ for Kalø. Stranddannelserne er svagt udviklede, og højtliggende Strandvolde og Erosionsterrasser naar indtil $3.1-3.5 \mathrm{~m}$ o. H., saaledes f. Eks. ved Vigens Østside mellem Rolsø Gaard og Vrinners Hoved og nordligere mellem Egens og Bregnet Kirke.

Paa Vestsiden af Aarhus Bugten har Kysten i Stenalderhavets Tid været langt mere indskaaret end i Nutiden. Sydøst for Skjødstrup dækkedes et ret betydeligt Areal af Havet, og mellem Egaa og Vejlby, $\mathrm{N}$ for Aarhus, naaede en bred Bugt langt ind i Landet, omtrent ind til Aarhus-Randers Landevej. Foran den førstnævnte Bugt aflejredes der under Landhævningen en bred, flad, af æg- til haandstore Sten bestaaende Strandvold, der udgik fra Sydvest fra Kysten ved Skjering og voksede ud mod Nordøst og Nord. Dens Højde er 3.7-3.9 m o. H. I Bakkerne mod Sydvest ved Strandvoldens Rod ses en Erosionsterrasse $3.9 \mathrm{~m} \mathrm{o}$. H. Nutidsstrandvolden har kun en Højde af 1-1.2 m. Den sydlige Bugt mellem Egaa og Vejlby laa mere ubeskyttet, og Stranddannelser findes flere Steder i dens ydre Del. Langs Bugtens Vestside strækker der sig saaledes en bred, flad, smaastenet Strandvold fra Sindssygehospitalet Nord paa, parallelt med den tidligere Kyst; Strandvolden naar til en Højde af indtil $3.6 \mathrm{~m} \mathrm{o.} \mathrm{H}$.

Fra det Sted, hvor Aarhus nu ligger, har der i Stenalderhavets Tid strakt sig en ca. $12 \mathrm{~km}$ lang, smal Fjord ind i den Lavning, gennem hvilken Aarhus Aa flyder, og hvis indre Del nu delvis udfyldes af Brabrand Sø. Skønt den ydre Del af den tidligere Fjord paa sine Steder kun har haft en Bredde af ca. $200 \mathrm{~m}$, findes der dog $\mathrm{i}$ de marine Dyndlag inde omkring Brabrand Sø Rester af en temme- 
lig rig Fauna, i hvilken baade Østers og et Par Tapes-Arter er repræsenterede. Forekomsten af Strandskaller i Engene ved Constantinsborg, en halv Snes Kilometer fra Fjordens Munding, omtales allerede i 1886 af Erstev.

Et oplysende Profil gennem de marine Lag blottedes i 1904 ved Østenden af Brabrand Sø ved Undersøgelsen af et Kulturlag fra den ældre Stenalder. Tæt ved Søens Bred var Lagfølgen: nederst Tørv fra Fastlandstiden, derover Sand og Grus med rullede Skaller af marine Mollusker, altsaa en Stranddannelse, der vidner om den begyndende Landsænkning; derover leret Sand med Skaller, og over dette et Lag af marint Dynd med Skaller af Østers, m. m. Over Dyndlaget, der repræsenterer Sænkningens Maksimum, den højeste Vandstand, gentages den samme Lagfølge, som fandtes under Dyndet, kun i omvendt Orden: først skalførende Sand, derover Strandgrus og Strandsand og øverst en begyndende Tørvedannelse. Profilet viser altsaa en Sænkning af Landet fra Fastlandstiden (den nedre Tørv) til Stenalderhavets Tid (Dyndlaget), og derefter atter en jæun Landhævning op til det nuværende Niveau. Medens de i det foregaaende oftere omtalte Affaldsdynger fra den ældre Stenalder er dannede dels ved Landsænkningens Maksimum, dels senere under den begyndende Landhævning, er der ved Brabrand fundet Oldsager i samtlige marine Lag; dette Sted har altsaa været beboet saavel under Landets Sænkning som under den følgende Landhævning. De i Dyndlagets nederste Del og i de derunder liggende marine Lag fundne Redskaber, eller rettere de forskellige Redskabstypers indbyrdes Mængdeforhold, tyder da ogsaa paa en noget ældre Kulturperiode end den, hvori Affaldsdyngerne dannedes.

Inde $\mathrm{i}$ den snevre Brabrand Fjord, hvor Bølgeslaget har været ubetydeligt, er hævede Strandlinjer meget svagt udviklede og i mange Tilfælde skjulte under yngre Tørvelag. Ved den overfor omtalte Udgravning ved Østenden af Brabrand Sø fandtes Strandgrus indtil $1^{3 / 4}$ m o. H., og i Nærheden maaltes en Erosionsterrasse, der laa $2.0 \mathrm{~m}$ o. H. Paa Grundlag af disse Tal kan man dog næppe dømme om Landsænkningens Størrelse i dette Terrain.

Øen Anholt, der ligger omtrent $50 \mathrm{~km}$ Nordøst for Grenaa, bestaar af en indtil $48 \mathrm{~m}$ høj, glacial Banke og et Øst for denne liggende stort Sletteland, der delvis er dækket af Klitter. Slettelandet, der udelukkende bestaar af Strandsand og Strandgrus, har inde ved Højlandet en Bredde af $4 \mathrm{~km}$ og strækker sig herfra som en spidsvinklet Trekant $9 \mathrm{~km}$ ud $\bmod \varnothing \mathrm{N} \varnothing$. Fra den yderste Spids af Landet, Totten, skyder det smalle, rygformede Osterrev sig endnu $10 \mathrm{~km}$ videre ud under Havet i samme Retning. 
Det store System af Strandvolde, hvoraf Slettelandet bestaar, viser, hvorledes dette er bygget op, efterhaanden som Landhævningen skred frem. Strandvoldene udgaar alle fra Højlandets Sydende, Sønderbjerg, og breder sig herfra vifteformet ud $\bmod \mathrm{N}$, NNØ og NØ; de afskæres skarpt af Øens Nordkyst, hvor de staar med en stejl Skrænt ned mod den nuværende Havstok. Længst mod Vest, inde under Højlandet, er Strandvoldene stenfattige; de bestaar af Sand og fint Grus, og Sten af et Ægs Størrelse er sjældne. Længere mod Øst bliver de mere stenede, og de Strandvolde, der fra Sønderbjerg løber mod Nordøst ud til Nordkysten tæt Vest for Fyret, ligger paa Sandsletten som skarpt markerede Rygge med Sten fra en Haands til et Hoveds Størrelse. Længere mod Sydøst aftager Stenenes Størrelse igen, og ved den nuværende Sydøstkyst findes kun Sand. Vinden, der virker med stor Kraft ude paa det flade, vegetationsløse og ørkenagtige Sletteland, har eroderet stærkt paa de stenfattige Strækninger; derved er de ældste, nærmest Højlandet liggende Strandvolde, der som næunt bestaar af finkornet Materiale, blevet betydelig formindskede i Højde og er nu lavere end de udenfor liggende, yngre, storstenede Strandvolde. Disse, der maa være aflejrede, da Landet allerede var hævet noget, naar til en Højde af $10 \mathrm{~m}$ o. H. Noget Maal for hele Landhævningens Størrelse paa Anholt giver Strandvoldenes nuværende Højde altsaa ikke, og inde langs Randen af Højlandet har Erosionen samt Aflejringen af Flyvesand langs Bakkefoden udvisket ethvert Spor efter Stenalderhavets maksimale Udbredelse.

Ude paa Slettelandet er der fundet talrige, fra den yngre Stenalder hidrørende Flintredskaber, Forarbejder til saadanne samt store Mængder af Flintaffald fra Tilhugningen, samlet paa begrænsede Pletter. Disse Værkstedspladser er for en Del knyttede til enkelte af de stenede Strandvolde, der kan følges gennem hele Øen fra Sønderbjerg til Nordkysten et Par Kilometer Vest for Fyret, og som derfor maa antages at angive den Tids Kystlinje.

\section{Kystlandet mellem Bovbjerg og Ringkøbing Fjord.}

Langs Jyllands Vestkyst Syd for Bovbjerg findes talrige Vidnesbyrd om, at der efter Fastlandstiden fulgte en Sænkning af Landet; men der er intet, der tyder paa, at denne Sænkning havde sit Maksimum i den ældre Stenalder, samtidig med Landsænkningens Maksimum og Stenalderhavets største Udbredelse i det nordøstlige Danmark. Endvidere er det endnu uafgjort, hvorvidt Landsænkningen 
Syd for Bovbjerg er bleven afløst af en Landhæuning; i alt Fald vil en saadan mulig Landhævning ikke i Tid kunne sammenstilles med den i de foregaaende Afsnit beskrevne Landhævning, ved hvilken Stenalderhavets Kystlinjer og Aflejringer hævedes op til større eller mindre Højde.

I Kystlandet mellem Bovbjerg og Ringkøbing er Strandvolde og Strandlinjer yderst svagt udviklede; de findes dog hist og her, men aldrig i større Højde end ca. $2 \mathrm{~m}$ o. H., det vil sige til et Niveau, hvori Strandlinjer i disse Egne vil kunne dannes ogsaa i Nutiden under de særlige Naturforhold, der gør sig gældende i dette Terrain. De store Laguner, Nissum Fjord og Ringkøbing Fjord med den nu delvis udtørrede Stadil Fjord er nemlig afspærrede fra Vesterhavet ved lange, lave Tanger, gennem hvilke der under normale Forhold fører smalle Afløbskanaler ud til Havet. Til Tider lukker Vesterhavet disse Kanaler, og sker dette om Foraaret ved Tøbrud, naar Aaløbene fører store Mængder Ferskvand ud i Lagunerne, vil Vandstanden $\mathrm{i} \gg$ Fjordene« stige, saaledes at der foraarsages Oversvømmelser af meget betydeligt Omfang. Til andre Tider kan Vesterhavet bryde saa brede Aabninger i de smalle Tanger, at der med Storm fra Sydvest og Vest vil presses uhyre Mængder Havvand ind i Lagunerne; med den stigende Vandstand oversvømmes de omliggende Engstrækninger med Saltvand til stor Højde. Som Vidnesbyrd om saadanne Perioder kan man langt fra de nuværende Kyster og højt over Fjordens normale Vandstand finde Strandlinjer og Stormflodshavstokke, bestaaende af Sand, fint Grus og Rester af Fjordens Fauna. Ved Bedømmelsen af den Højde, hvortil gamle Strandlinjer og marine Aflejringer kan findes inde i disse Laguner, kan man derfor ikke gaa ud fra en konstant Vandflade, men maa regne med en Vandstand, der varierer fra 0 til mere end $1^{1 / 2} \mathrm{~m}$ over Middelstanden i Vesterhavet.

Lagfølgen i Strandengene omkring Lagunerne og i de udtørrede Dele af disse er paa mange Steder: nederst glaciale eller senglaciale Ler- og Sandlag, derover Tørv af meget vekslende Mægtighed og Beskaffenhed, og ørerst et tyndt Lag Klæg, afsat i salt eller brakt Vand. Paa enkelte Steder er der senere blæst Flyvesand ud over Klæglaget, eller dette kan, nær Aamundingerne, være dækket af Ferskvandsdynd, eller af Sand, der er ført op med Stormfloder.

Det nederste Tørvelag, hvis dybeste Lag maa hidrøre fra Fastlandstiden, findes blandt andet under store Dele af Nissum Fjord. K. Larsen-Vestergatrd angiver ${ }^{1}$ ), at Tørvelaget her kan have en Tykkelse af over $6 \mathrm{~m}$, og at det indeholder Eg, El, Hassel og Birk.

1) K. Larsen-Vestergand. 1911. Stenalderhavets Udbredelse og efterladte Spor i Hardsyssel. Hardsyssels Aarbog. Bd. V. København. 
Det naar i Nissum Fjord til en Dybde af 5-6 $\mathrm{m}$ under Havets Niveau. Forсhнамmer omtaler allerede i 1839 ved Naturforskermødet i Göteborg, at der i Nissum Fjord ud for Nørre Vosborg findes Tørvelag flere Fod under Havets Overflade, og at deres Bund »er bedækket af Fyrrerødder, der aabenbart staae endnu paa deres Voxested «. J. JEPPESEn nævner ${ }^{1}$ ), at da et engelsk Selskab i Aarene omkring 1880 søgte at udtørre den sydøstlige Del af Nissum Fjord, Felsted Kog, fandtes to submarine Moser, den ene VSV for Nørgaard Odde i Staby Sogn, den anden ØNØ for samme Odde, ud for Hasselbæk. I den nu udtørrede Del af Stadil Fjord fandt Rambusch ${ }^{2}$ ) to Tørvemoser dækkede af $0.3 \mathrm{~m}$ Sand og indeholdende Eg og Hassel. Den ene, der havde et Areal af 16 ha, laa ud for Nørkjær Enge, SV for Vedsø Kirke, den anden, 8 ha stor, fandtes ud for Fuglbjerg, VNV for Stadil Kirke. HaRTz omtaler ${ }^{3}$ ), at der under Klæglaget langs Kysten af Ringkøbing Fjord ligger Tørvelag, der naar indtil $2.2 \mathrm{~m}$ under Havets Overflade, og som bestaar af almindelig Kærtørv med Rester af Birk og hist og her noget Eg. Tørvelag svarende til de ovennævnte findes ogsaa længere mod Vest, ude langs den nuværende Kyst og endog ude under Havet. For nogle Aar siden blottedes saaledes ved Havets Angreb en Tørvemose i Havstokken ved Sydenden af Bovbjerg. Tørven, der indeholdt en Del Rodstød, bl. a. af Eg, blev opgravet og benyttet af Beboerne. Paa samme Maade blottedes i Havstokken $600 \mathrm{~m} \mathrm{~N}$ for Krogen, VSV for Stadil Kirke, »et Skovlag « med tykke Birkestammer, der stod rodfæstede i fedt Ler. Ved Søndervig, ud for Nordenden af Ringkøbing Fjord, driver der stadig store Blokke af Tørv og Gytje ind paa Stranden; en Tørvemose maa aabenbart findes i Havbunden ud herfor. Et lignende Tørvelag skal findes noget sydligere, i Havstokken ved Nørre Lyngvig, og er omtalt af Hartz (1900. anf. St.).

Dannelsen af disse til Dels ret dybtliggende Tørvelag er utvivlsomt begyndt i Fastlandstiden; men om det Tidspunkt, hvor Mosedannelsen blev afbrudt ved Landets Sænkning og Havets Indtrængen, vides der meget lidt. Om de submarine Moser, der for 40 Aar siden kom til Syne under Forsøget paa at udtørre den indre Del af Nissum Fjord, giver J. Jeppesen nogle ejendommelige Oplysninger (anf. Sted). Mosen ØNØ for Nørgaard Odde kaldes af Fiskerne »æ Klyngraw «, og om Mosen VSV for Nørgaard Odde siges, at den var fuld af store Tørvegrave med mandshøje Brinker. Endvidere omtaler

$\left.{ }^{1}\right)$ J. Jeppesen. 1910. Jordbunds-Sænkningen ved Nissum Fjord. Hardsyssels Aarbog. Bd. 4. Kjøbenhavn.

$\left.{ }^{2}\right)$ S. H. A. Rambusch. 1900. Studier over Ringkøbing Fjord. København.

$\left.{ }^{3}\right)$ N. Hartz. 1900. Trak af Fjordens geologiske Udvikling, i S. H. A. Rambusch. 1900. Studier over Ringkøbing Fjord. 
saavel Jeppesen som K. Larsen-VestergaARD ${ }^{1}$ ), at der ved Udtørringsarbejdet kom en Del nedrammede, $10-15 \mathrm{~cm}$ tykke Prele til Syne; de fandtes paa 3 Steder ude i Fjorden ved et gammelt, i Fjordbunden endnu synligt Aaløb og menes at være Rester af Broer. Disse Samlinger af Pæle er nu, efter at Udtørringen er opgivet, dækkede af over $1 \mathrm{~m}$ Vand.

Om de næunte, 40 Aar gamle Iagttagelser er rigtigt tydede, og .om Landsænkningen i denne Egn har vedvaret til et saa sent Tidspunkt, ind i den historiske Tid, faar staa hen. Det kunde f. Eks. tænkes, at de gamle » Tørvegrave« og stejle Brinker var fremkomne ad naturlig Vej ved Vandløbs Udgravning, eller at det var Strømhuller, udgravede i den løse Kærtørv, da Fjorden brød ind herover. Dette vil dog næppe kunne afgøres, før et nyt Forsøg paa Tørlægning atter bringer disse Moser frem for Dagen. Endnu et Vidnesbyrd om, at Landsænkningen k an have vedvaret langt ned i Tiden, anføres af Larsen-Vestergatrd (1911. anf. St.). Han nævner, at i første Halvdel af forrige Aarhundrede fandtes der nede i den brede, flade Lavning, der adskiller Nørfjand og Sønderfjand fra Sønder Nissum, en Del smaa Broncealderhøje med Lerkar paa et saa lavt Niveau, at Højvandet nu ved Stormflod kunde naa op til dem.

Den marine Klæg, der dækker Tørvelagene, har i Reglen en meget ringe Mægtighed, indtil $1^{1 / 2} \mathrm{~m}$, (i Vester Stadil Fjord angives Tykkelsen dog at kunne være indtil $3 \mathrm{~m}$ ), og indeholder en meget fattig Fauna, saaledes af Mollusker kun Mytilus edulis, Cardium edule og Litorina litorea. I Ringkøbing Fjord har der, før Udløbet flyttedes langt Syd paa til Nymindegab, og Vandet i Fjorden derved blev omtrent fersk, levet en rigere Fauna, af Mollusker bl. a. Ostrea edulis og Tapes pullastra, og af disse er Ostersen endog først uddød i Slutningen af det 18de Aarhundrede. Der er derfor ikke i Klæglagets Fauna noget der tyder paa, at Klægen skulde være aflejret under udpræget marine Forhold eller i Litorinatiden; den kan for saa vidt lige saa godt hidrøre fra sen historisk Tid. Den Højde, hvortil Klægen findes, er i Ringkøbing Fjord (i Følge N. HARTz) $1.5 \mathrm{~m}$, altsaa ikke mere end den Højde, hvortil Fjordens Vandspejl kan hæves under Storm eller Højvande i Vesterhavet, paa Tider hvor Forbindelsen med Havet ikke er for smal. Den fede Klæg er dog næppe aflejret under de egentlige Stormfloder; men har der i Perioder været forholdsvis fri Forbindelse mellem Vesterhavet og Lagunerne, maa Ebbe og Flod utvivlsomt ogsaa have givet sig til Kende inde i Fjordene, maaske med forstærket Kraft. Følgen vil da - her hvor

1) K. Larsen-Vestergaard. 1910. Folke- og Fortidsminder fra Ulfborg Sogn. Hardsyssels Aarbog. Bd. 4. København. 
Saltvand og slamførende Aavand mødes - bliver en Aflejring af Klæg i Lighed med Marskdannelsen længere Syd paa langs Jyllands Vestkyst. I Engene omkring Stadil Fjord naar Klægen ikke til saa stor Højde, næppe til mere end $1 \mathrm{~m}$ o. H., og det samme er Tilfaldet i Engene omkring Nissum Fjord. Ogsaa for disse Strækningers Vedkommende gælder altsaa det samme, nemlig at Klægen ikke naar til større Højde end den, hvortil Vandspejlet vil kunne stige under de nuværende Niveauforhold, saafremt blot Forbindelsen med Vesterhavet er nogenlunde uhindret.

Hverken langs Nissum Fjord, Stadil Fjord eller Ringkøbing Fjord findes der Stranddannelser af Betydning; de Strandvolde, der ses langs Øst- og Nordsiden af Ringkøbing Fjord, f. Eks. tæt NV for Ringkøbing, mellem Byen og Gammelsogn Kirke, naar til en Højde af indtil $1.9 \mathrm{~m} \mathrm{o}$. H. og bestaar af fint Grus og nøddestore Sten. Det er ikke Vesterhavs-Havstokke, men smaa Strandvolde af Fjordeller Indsø-Typen, og deres Højde er ikke større, end at de kan tænkes at være aflejrede ved Stormfloderne.

Af det ovenfor anførte vil det fremgaa, at der ikke findes noget, der tyder paa, at Aflejringen af Klæglaget skulde være foregaaet i Litorinatiden eller i en Tid, hvor Niveauforholdene har været væsentlig forskellige fra Nutidens. Aflejringen af Klægen er dog betinget af en noget friere Forbindelse mellem Vesterhavet og Lagunerne, end Tilfældet har været i det 19. og 20. Aarhundrede; paa den anden Side viser Fraværelsen af Vesterhavshavstokke, at Lagunerne - og blandt disse særlig Nissum Fjord og Stadil Fjord - aldrig har været aabne Bugter fra Vesterhavet, men at de ved Landomraader eller smalle Landtanger har været mere eller mindre afspærrede fra Havet. Endelig findes der ingen højtliggende Stranddannelser, der kan benyttes som fuldgyldigt Bevis paa, at denne Kyststrækning har ligget lavere end i Nutiden, og at den derefter er blevet hævet op til sit nuværende Niveau.

I Fastlandstiden har disse Egne derimod ligget langt højere end nu, og der er siden da foregaaet en jævn Landsænkning. Det maa antages, at paa det Tidspunkt — i den rldre Stenalder — da Stenalderhavet havde sin største Udbredelse i det nordlige og østlige Jylland, laa Egnene omkring Nissum Fjord og i Særdeleshed omkring Ringkøbing Fjord endnu stadig noget højere end i Nutiden; rimeligvis laa Grænsen mod Vesterhavet noget udenfor (Vest for) den nuværende Kystlinje, og Nissum Fjord, Stadil Fjord og Ringkøbing Fjord var maaske endnu Ferskvandssøer ligesom i Fastlandstiden. Medens det nordlige og østlige Jylland derefter, i den yngre Stenalder, atter hævedes, fortsattes Sænkningen uafbrudt mod Sydvest, og til sidst trængte Saltvand ind over de laveste Partier, de nuværende Laguner. Hvornaar 
Landsænkningen ophørte, er det endnu ikke muligt at udtale noget bestemt om; det vil kun kunne afgøres ad arkæologisk Vej.

Det ligger næer i saa Henseende at sammenstille Kyststrækningen fra Bovbjerg til Blaavandshuk med den Syd derfor liggende Strækning fra Blaavandshuk til Sild, hvor Landsænkningens Maksimum, som det tidligere er vist ${ }^{1}$ ), først indtraf ved Slutningen af Broncealderen eller i den nærmest følgende Tid. Men medens det har kunnet vises, at der paa den sydlige Kyststrækning derefter er foregaaet en Landhavning, omend af ringe Størrelse, efter Broncealderen, haves der ingen sikre Vidnesbyrd om, at denne Hævningsbølge ogsaa er naaet frem til Egnene ved Ringkøbing Fjord og Nissum Fjord.

Der er saaledes ingen Sandsynlighed for, at Stenalderhavet har dækket noget af det nuværende Landomraade mellem Nissum Fjord og Ringkøbing Fjord, eller at de derværende marine Lag i Tid kan sammenstilles med Litorina- (Tapes-) Lagene i det nordøstlige Danmark. De Syd for Bovbjerg liggende Arealer, der nu dxkkes af marine Lag, er derfor paa medfølgende Kort angivne ved en lysere blaa Farve end de Strækninger, der dækkedes af Stenalderhavet ved Litorina-Sænkningens Maksimum.

$\left.{ }^{1}\right)$ Sophus Müller. 1913. Sønderjyllands Stenalder. Aarb. for nord. Oldkyndighed og Historie. III. Række. Bd. 3. Kjøbenhavn.

1914. Sønderjyllands Broncealder. Aarb. for nord. Oldkyndighed og Historie. III. Række. Bd. 4. Kjøbenhavn.

A. Jessen. $\quad$ 1916. Marsken ved Ribe. D. G. U. II. Række, Nr. 27. Kjøbenhavn. 
Summary. 



\section{The Extension of the Stone-age Sea (Tapes-Litorina Sea) in Northern Jutland.}

The northern part of Jutland, after the glacial period, was subject to various changes of level. Simultaneously with the melting of the inland-ice the late-glacial subsidence commenced, during which the land towards the north-east near Skager Rack, stood 60 metres lower than at present; in the middle part of Vendsyssel (the eastern part of the country north of the Limfjord) 40 metres; and near the town of Aalborg, situated on the Limfjord, about 20 metres lower than at the present time. South-west of a line drawn through the towns of Lögstör and Grenaa to the north coast of Zealand (Sjælland) the land stood at that time higher than at the present time, so that late-glacial freshwater deposits are now found below sea-level. During the late-glacial ice-sea period Saxicava-sand and Yoldia-clay were deposited towards the north-east, where the land was lowest. The Yoldiaclay contains an extreme arctic fauna, characterized by Portlandia arctica, Tellina Loveni and Tellina Torelli. Afterwards, during the late-glacial emergence, a coast-formation was deposited on the north coast of Vendsyssel - the Zirphæa-deposit - the fauna of which is boreal in nature and is characterized by Zirphea crispata. This layer, which consists at the bottom of coarse gravel, and at the top of fine clayey sand, shows that the late-glacial uplift was interrupted, at the beginning of the forest-period, by a slight depression of the land.

During the resumed uplift the northern part of Jutland, during the Ancylus time, - the continental period - rose to a somewhat higher level than it stands at the present time. Numerous submarine peat bogs and river-channels along the coasts and in the former and the present fjords indicate the seaward extension of the land at that time. Farthest towards the north, at Frederikshavn and Skagen, the land stood at least at the same height as at the present time, at Aalborg certainly 6 metres higher, and further towards the south and south-west even higher; the coast-line-almost everywhere has extended far beyond the present coast. Limfjord, the narrow, winding sound, which leads from the North Sea to the Cattegat through the northernmost part of Jutland, at that time, towards the west, consisted of a series of large, connected lakes, which towards the east had their outlet through a river, the present narrow, deep channel through the eastern part of the Limfjord from Lögstör past Aalborg to Hals. This river-channel still exists very distinctly excavated in the sea-bottom, and at its mouth, towards the east, the river has formed a delta - now submarine - (with submarine peat bogs), through which it has cut out several channels.

During the subsequent Tapes-Litorina subsidence the sea gradually 
extended over great parts of the former land with its forests and peat bogs. North-east of a line which may be drawn from the Nissum Fjord (immediately south of the western entrance to the Limfjord) towards the south-east across Denmark, the land sank to a level lower than that of the present time. The maximum of the subsidence occurred in the earlier part of the Danish Neolithic Stone Age (Campignien), hence the reason for the use of the term »Stone-Age Sea«. At this point of time the subsidence south-west of the line mentioned above had not ceased, but the land still stood at a higher level than at the present time; while afterwards the subsidence of the land in the north-eastern part of Denmark was followed by a rise which continued at any rate into the Bronze Period, in the south-western part the subsidence was continued until the land there, at unknown time, attained its present level.

Farthest towards the north, during the maximum of the Tapes-Litorinasubsidence, the coast-line ran from Frederikshavn towards the north-west, past Tversted and Uggerby to Hirshals. The large tongue of low land, Skagens Odde, is newly formed land, built up by the joint action of the rise of the land and the transport of sand and gravel by the longshore currents. Broad bars of sand and gravel were deposited along the old coast, partly from Frederikshavn towards the north-west, and partly from Tversted towards the east-north-east. These systems of old beaches were joined and curved towards the north-east to a clay-bank - at that time submarine - north of Raabjerg. Around this basis the tongue of land increased in breadth and length, new beach-ridges (Strandvolde) being formed outside the old nucleus, as annual rings in a tree-stem. In the lagoons, between the bars and the old coast, marine clay with a Tapes-fauna was deposited. When the tongue of land had been built rather far out, the current eat away the west side of the newly formed land, and great parts of it have now disappeared, so that old lagoon-deposits now lie unprotected out towards the Skager Rack as, for instance, at the mouth of the stream Tversted Aa. Simultaneously, the longshore current along the east side of the tongue of land turned and ran southwards, and so there was formed across the broad bay south of Raabjerg church, a system of narrow sand-ridges, „Rimmer", separated by broader depressions, now filled with peat. This system of sand ridges issues from one spot near the north and from thence spreads out like a fan towards the south-west, south and south-east. The height is greatest towards the north and decreases towards the south. The whole system has a breadth of $4 \mathrm{~km}$ and a length of $10-12 \mathrm{~km}$.

The most elevated Tapes-Litorina deposits on Skagens Odde occur partly south-west of Raabjerg church (where a beach-ridge occurs as high as 14.7 metres above sea-level) and partly along the old coast; the flat bar along the high land occurs at a height of about 14 metres and in the lagoon between this bar and the high land marine-clay (which in several places rests on peat of the Ancylus time) is found up to about $12^{1 / 2}$ metres above sea-level. The post-glacial uplift in this district must therefore be assumed to be of $12-13$ metres.

From Tversted westwards past Uggerby to Hirshals, in some narrow former fjords, marine clay is found up to 13 metres above sea-level, and farthest westwards, at the promontory near Hirshals beach-ridges of gravel are found up to a height of 14.9 metres above sea-level.

Along the east coast of Vendsyssel former fjords have extended rather far inland. In a fjord along the stream, Bangsbo Aa, immediately south of 
the town of Frederikshavn, marine clay and mud are found up to a height of 12.5 metres above sea-level, and in front of the entrance to the valley there is a large beach-ridge as high as 15 metres above sea-level. In the former fjord along the Sæby Aa, within the town of Sæby, marine mud is found up to a height of 10 metres above sea-level, and in front of the entrance to the fjord there is a beach-ridge 13.5 metres above sea-level. Along the stream, Voers Aa, a fjord extended far inland, and on the plain around Voer church it divided into several long, narrow branches, forming a peculiar system of fjords. The marine layers have a thickness of $6-8$ metres, rest on peat-bogs of the Ancylus time, and are found up to a height of 9 - 10 metres - in the northern-most branches of the fjord to $10^{1 / 2}$ metres - above sea-level.

Along the southern part of the east coast of Vendsyssel the raised beaches are only slightly developed. North of Asaa lagoon-formations are found up to a height of 8 metres above sea-level; in the large tract of low land around the stream Gjeraa, the fjord-sediments have a thickness of as much as 8 metres and occur up to a height of 8.8 metres above sea-level. Towards the south-west this fjord was connected with the Limfjord by a sound. At Ulsted shore-lines are found 8.5 metres above sea-level and marine clay up to a height of 7.8 metres above sea-level.

The island of Læsö, east of Sæby, was during the maximum of the Tapes-Litorina subsidence completely covered by the sea. The island consists of a flat bank of late-glacial Yoldia-clay upon which gravel-ridges were deposited during the rise of the land; between these beach-ridges fine sand was afterwards deposited. At one of these beach-ridges the disintegrated skeleton and several teeth of a cachalot whale (Physeter macrocephalus) have been found. The highest beach-ridges lie 11 metres above sea-level, but are evidently more recent than the maximum period of the submergence.

On the west coast of Vendsyssel land has in some places been added to and in other places washed away from the coast. From Hirshals, where the beach-ridges of the Tapes-Litorina Sea occur up to 14.9 metres above the sea-level, to Lönstrup, the sea has first eroded the coast; afterwards was formed a tract - one $\mathrm{km}$ broad - of elevated beach-ridges beyond the old coast. On the other hand, from Lönstrup to Lökken, much land has been washed away; this is best seen by the consideration of the almost circular hill, "Rubjerg Knude", the western half of which has been eroded, so that its highest point now lies on the coast. At the present time the rate of erosion of this stretch of coast is $100-200$ metres in the century.

From Lökken a broad tract of meadow-land stretches inland to the great plain of which the central part is now occupied by the Sphagnum-bog "Store Vildmose". In the Tapes-Litorina time the whole of this low land was covered by the sea; it did not, however, form a sound between the Skager Rack and the Limfjord, but a fjord, which extended northwards from the Limfjord, and which immediately outside Lökken was shut out from the Skager Rack by land which has now been washed away: in the elevated sea-bottom - the present meadows within Lökken - only typical fjordsediments are found, viz clay and mud, which rest on bogs from the Ancylus time. In addition to this, the fauna is a Limfjord-fauna, which shows a decrease, both as regards the number of the species and the development of the individuals, from south to north, from the Limfjord outwards towards Lökken. The marine clay deposited at the head of this former branch of the Limfjord, as a result of the land having been washed away, is now seen 
immediately north of Lökken in the cliffs facing the Skager Rack. It is found here up to a height of 8.3 metres; the terraces of erosion along the sides of the former fjord occur 9.5 metres above sea-level.

From the high land near Saltum and Hune towards the south-west to the hills near Tranum another large plain is found, consisting of marine strata. Here the conditions are similar to those at Lökken. This low land was never a sound between the Skager Rack and the Limfjord, but a large bay, an expansion from the Limfjord; the marine strata are clay and mud deposited in calm water, and the underlying peat bogs of the Ancylus time are still in existence in several places. In addition, the fauna in a decided Limfjord-fauna. Throughout the whole of the Tapes-Litorina time the Limfjord, at this place, was cut off from the open sea by a flat bar of gravel now covered by blown sand - which stretches from Hune to Tranum; at the places where the bar of gravel touches the high land, the latter has not been affected by the sea, but north and south of the places in question the high land is greatly eroded. The erosion was greatest in the direction of the Skager Rack, from Tranum, past Lerup to Svinklöv, a promontory consisting of white chalk (upper Senonien). There the Litorina coast occurs as an old sea-cliff, as much as 50 metres high, in front of which has been formed a plain of beach-sand, $3 \mathrm{~km}$ broad. There the present beach has a height of 3.1 metres; the beach-ridges of the Tapes-Litorina Sea are found op to a height of 8 metres above sea-level.

The coast-line of the south side of Vendsyssel has been greatly indented. From the east the sea reached inland to the town of Aalborg as a large bay; west and north-west of Aalborg the Limfjord of that time - as already mentioned - covered a large area. At Nörresundby there are beach-ridges 7-8 metres above sea-level; the terraces of erosion, around what was formerly islands north-west of this, occur 7-7.5 metres above sea-level, and the marine clay and mud at the head of the bays, 6-6.9 metres above sea-level. In the district around "Store Vildmose" marine clay and mud have a thickness of as much as 12 metres and in many places the deposits rest on peat-bogs from the Ancylus time. The height of the shore lines east of 》Store Vildmose $\approx$ is $8-8.5$ metres, towards the north, between Tise and Brønderslev, 8.5 -9 metres, and towards the west at Jetsmark 7-7.5 metres above sea-level.

On the island of Gjöl beach-ridges are found up to 7.8 metres above sea-level, and on Øland, which was more sheltered from the west wind, up to 6.3 metres above sea-level. During the Tapes-Litorina time the low land north of these islands was, as already mentioned, a large bay from the Limfjord, separated from the Skager Rack by a low bar of gravel. Towards the west, between Svenstrup and Tranum, beach-ridges occur 7.2 metres, and marine clay 5.3 metres above sea-level.

West of the high land between Svinklöv and Fjerritslev, where the Litorina coast occurs as an old sea-cliff, as much as 30 metres high, the greater part of the present land was covered by the sea owing to subsidence of the land, and only a few hills protruded as islands. Gradually the coastal current deposited bars of gravel from island to island; in the shelter of these, sand was deposited, and by uplift new land was thereby formed with an even, slightly curved coast-line which, as flat arches, link up a series of fixed points, usually areas of chaik or lime.

At the foot of the former sea-cliff, ${ }^{1} / 2 \mathrm{~km}$ to the south-west of Svinklöv, a layer of shell-gravel occurs $7.8-8.1$ metres above sea-level. Further south, west of Fjerritslev, beach-ridges are seen $7-7.8$ metres above sea-level. 
In some beach-ridges, lying south of Vust, bones of horses and domesticated oxen have been found at such a height that it must be assumed that, at this place, the land has been uplifted about one metre since the Bronze Age. North of Vust there is high land, a former island, the northernmost point of which, Bolbjerg, consists of Danien limestone. The present beach occurs here as high as 3.7 metres above sea-level. Out on the low land south-west of this, there are beach-ridges which extend from north-east towards southwest, and which are found up to the unusual height of as much as 9.4 metres above sea-level.

The formerly existing islands in this district show a very strong marine erosion on their north and west sides. The beaches along the foot of the slope are however frequently hidden by blown sand; only inland towards Limfjord are they uncovered, but there they are not so high as out towards the open sea. Thus beach-ridges and shore-lines are found between Tömmerby and Veslös where they occur up to $6-6.6$ metres above sea-level.

The hills between Østerild and the point of land near Hansted, which were formerly two elongated, peculiar islands, Hjardemaal lsland and Haustholm Island, consist of limestone (Danien) that rests on chalk (Senonien). They have straight, steep sides, the form and direction of which must be assumed to be due to tectonic changes. A very large and broad beach-ridge, which, west of the church of Hjardemaal, extends outwards from the old coast, has a height of 7.8 metres. The present beach near Hansted lies at a height of 3.5-3.8 metres above sea-level. In the former sounds between the islands a very rich Tapes-fauna is found.

The southern part of Thy was formerly a large island the east coast of which, inwards towards the Limfjord, is almost unaltered. On the west side, on the other hand, during the Tapes-Litorina time, the coast-line lay about $5 \mathrm{~km}$ within the present coast and was very irregular. West of the main island were several islets, frequently consisting of chalk or limestone, which by occurring as a skerry-fence (Skærgaard) broke the force of the ocean and afterwards, during the uplift served as points of supports for the sand and gravel deposited by the coastal-current. As a rule the old sea-cliffs are hidden by blown sand which, partly as dunes and partly as a layer of 8-12 metres thickness, has covered the western part of the country.

At Nissum Bredning, the most western expansion of the Limfjord, no beachridges of the North-Sea type are present, and in the uplifted layers of clay and sand no North-Sea fauna is found, but a typical Limfjord-fauna. The most western part of the Limfjord has therefore never been an open bay of the North Sea, but during the whole time from the Ancylus period to the present time, must have heen shut out from the sea by a low isthmus. The sea occasionally cut channels through this isthmus, which, however, were soon closed again owing to the great amount of sand carried by the current along the shore. There are numerous records of this isthmus having been broken through in historic times, but the channels have soon become filled up again with sand, and through the whole of the Middle Ages and to recent times this isthmus has been the usual road between north-western and southern Jutland. The present channel, the Thyborön Canal, was formed in 1863 , and has since been kept open and deepened artificially for the sake of the navigation and fishery in the Limfjord. Owing to the isthmus having been broken through at various times in the 19th century, it has retreated considerably, whereby much land has been lost, for instance a great part of the parish of Agger together with the old church. Both under the isthmus 
and west of it, out into the sea, there is now found marine clay with a rich fjord-fauna.

The raised beaches in the Nissum Bredning, which are of the fjord-type, do not occur at great heights; on the southern end of Thyholm at Oddesund, they lie $3.5-3.8$ metres above sea-level, and westwards at Agger 3.8 metres above sea-level. If we take into consideration the height of the present beach, the figures given above do not show evidence of any considerable rise of land; here we are also close to the south-western limit of the postglacial area of elevation.

On the island of Mors there are found towards the north, shore-lines up to a height of 5.6 metres, and fjord deposits to 3.5 metres above sealevel, the latter figure must indicate approximately the uplift in this place. Formerly several fjords penetrated far into the island, as for instance from Dragstrup Vig for $6-7 \mathrm{~km}$ towards the east past Eerslev; there the marine layers rest on peat bogs of the Ancylus time. On the peninsula of Salling situated south-east of Mors, the coast-line was highly indented during the Tapes-Litorina time, and elevated beach-ridges occur now in many places. Towards the south-west they are found up to a height of $3.4-3.7$ metres, on the west side to $4-4.2$ metres, on the north side 4.7 metres and on the east side at Hvalpsund 4.2-4.7 metres above sea-level. On the little island of Fur, north of Salling, beach-ridges occur to 4.4 metres above sea-level.

The two fjords situated east of Salling, viz, Skive Fjord and Hjarbæk Fjord stretched further towards the south in the Tapes-Litorina time, and branched far more copiously than at the present time, narrow fjords having extended through the present river-valleys both towards the south and east. On the east side of the Lovns Bredning, shingle and shell-gravel are found up to 4.7 metres above sea-level. North of this at Ertbölle (Ertbölle) Head there is a very large and carefully investigated shell mound (Kökkenmödding) of the Older Neolithic Stone Age; from this locality this culture-period is often named the Ertbölle-culture. Near Bjönsholm where a couple of fjords have penetrated inland there occurs a belt of beach-ridges, one $\mathrm{km}$ broad; the ridges gradually ascend from the coast inland towards the hills up to 6.s metres above sea-level. At Aggersund, north of the town of Lögstör stony beach-ridges occur which westwards out towards the open part of the Limfjord, are found up to 6.5 metres above sea-level, while northwards at the narrow part of the sound they occur up to a height of only $5-5.3$ metres above sea-level.

Along the southern side of the Limfjord, from Lögstör past Aalborg to - Hals, the sea has covered considerable areas and penetrated far inland as fjords. The former shores now stand as steep sea-cliffs out towards the elevated sea-bottom; shore-lines and beach-ridges are seen at high levels in numerous places. Thus at Sebbersund beach-ridges are found up to 6.3 metres above sea-level, and on the former island at Nörholm, 7.2-7.5 metres above sea-level. From the town of Aalborg a narrow fjord penetrated 26 $\mathrm{km}$ inland past Svenstrup and Ellidshöj to Gravlev; the marine clay and mud layers in the former fjord have a thickness of as much as 6 metres and are covered by $2-7$ metres of freshwater deposits. Towards the east the fjord was connected with the Cattegat by several sounds by which the old high land was divided into larger and smaller islands. As the foundations of several of these islands consist of chalk, they often stand with high, steep faces out towards the flat, newly formed land. The elevated, reclaimed sea-bottom has a great extension eastwards, out towards the Cattegat, as 
may be seen from the map; the marine layers are to a great extent covered by a Sphagnum-bog, "Lille Vildmose . From the small hill, Muldbjerge, beach-ridges are spread out as a fan towards the north. At Muldbjerge the shore-line of the Tapes-Litorina Sea lies more than 7.8 metres, and southwards at Als it is 6.5 metres above sea-level. West of this, from Storvorde and Gudumlund near Limfjord and southwards past Kongstedlund and Bælum to the Mariager Fjord, the old coast is seen very distinctly with shorelines lying at a height of $6-6^{1 / 2}$ metres above sea-level.

Along Mariager Fjord, between the towns of Hadsund and Mariager, numerous elevated beach-ridges occur, usually as high as $4^{1 / 2}$ metres above sea-level. Some of the beach-ridges lie somewhat higher, $5-5^{1 / 2}$ metres above sea-level, but there it is not possible to draw any fixed boundary-line between the post-glacial raised beaches from the Tapes-Litorina time and some undoubtedly late-glacial beach-ridges, situated south-west of Hadsund, which lie 6.8 metres above sea-level. Along this part of Mariager Fjord there are numerous shell mounds (Kökkenmöddings) from the Older Neolithic Stone Age (Ertbölle culture).

In the Tapes-Litorina time the entrance to Randers Fjord was much broader than at present; at Øster Törslev raised shore-terraces are found up to a height of $5.3-5.6$ metres, at Støvring to $5-5.3$ metres and east of Randers to 4.7 metres above sea-level. While at the present time the fjord only extends to a point $10 \mathrm{~km}$ east of Randers, at the Tapes-Litorina time it had a length of $65 \mathrm{~km}$, and penetrated through older, late-glacial rivervalleys to the central part of Jutland. By borings, marine layers have been demonstrated inland towards the west, through the broad valley along the stream Nörreaa, as far as a few kilometres south-east of the town of Viborg. Even here at the head of this long, narrow fjord, where the marine layers are covered by freshwater deposits and rest on peat-bogs of the Ancylus time, the fossil marine fauna is fairly rich.

In the Tapes-Litorina time the Randers Fjord was connected with the Cattegat partly through its present outlet, partly towards the east by a broad sound past Ørsted and Hevringholm, and partly towards the southeast through a long, narrow and highly winding sound, which can be traced past Gl. Estrup, Kolindsund and further on to the town of Grenaa. The presence of the last-mentioned sound and its numerous branches has been demonstrated by borings, the marine layers occurring there being covered by peat as much as 10 metres thick. The eastern and broad part of the sound, Kolindsund, was a lake as late as 1874. There the post-glacial layers are as much as 16 metres thick, and the fossil fauna is very rich. Along the former coasts settlements (Kökkenmöddings) from the Stone Age occur.

Along the coast of the peninsula of Djursland well-developed raised beaches and shore-lines are found. Northernmost, at the former Hevringholm Sound beach-ridges are found as high as $6-6.5$ metres above sea-level. Towards the east, at Gjerrild, beach-ridges are found up to 7 metres above sea-level, and at the promontory, Fornæs, farthest to the east, to 7.8 metres above sea-level. The present beach lies there $2.5-2.7$ metres above sea-level. Further to the south, at Hoed and Rugaard, beach-ridges of the Tapes-Litorina Sea occur to a height of 6.9 metres above sea-level, and still further to the south at the lake of Stubbe and at Draaby, a much-branched fjord extended inland. On the peninsula on which the town of Ebeltoft is situated, the elevated beach-ridges occur up to a height of 5.7 metres, and on the peninsula of Helgenæs, lying south-west of this, $4 .{ }_{.3}-5.2$ metres above sea-level. 
Along the bay, Kalö Vig, the raised beaches are less well-developed; at the head they are found up to a height of $3.1-3.5$ metres and towards the west to 3.7 -3.9 metres above sea-level. At the town of Aarhus (at the southern edge of the map) shingle is found to a height of 3.6 metres above sea-level, and in a former, very narrow fjord, which extended from Aarhus $12 \mathrm{~km}$ inland, shore-lines occur 2 metres above sea-level.

From what has been stated above it will be seen that the height at which the Tapes-Litorina deposits occur is greatest towards the north-east outwards towards Skagen, and that their height above sea-level decreases from there, both on proceeding towards the south-west and the west out towards the western end of the Limfjord and also on proceeding towards the south along the east coast of Jutland to Aarhus. As some beach-ridges and shore-lines are formed out towards the open sea, and others within protected fjords, the figures given must be used with caution for determining the actual amount of the rise of the land. It will however be seen that this increases very gradually from the south-west towards the north-east.

South-west of the demarcation-line of the post-glacial rise of land, mentioned on p. 106, the land in the Tapes-Litorina time was situated higher than at present, and not until a later date did it sink to its present level. In these districts no beach-ridges are found at greater heights than those at which they can be formed at the present time during spring-tides. Peculiar conditions make themselves felt in the large lagoons on the west coast of Jutland (Nissum Fjord, Stadil Fjord and Ringköbing Fjord), where, during a gale, the water blowing on the shore rises to an unusually high level, by which in these fjords not only marine sand, but also marine clay and mud is deposited somewhat above mean water-level; but as these marine layers are much younger than the Tapes-Litorina deposits mentioned above they have been indicated on the map by a paler blue colour. Even if, in this district, along the west coast of Jutland, it is possible that the depression was succeeded by uplift, yet the latter was at any rate very slight and must have occurred in recent times, probably after the Bronze Age and simultaneously with the slight rise of land which can be demonstrated south of this in the marshy land at Esbjerg, Ribe and on Fanø. 
STENALDERHAVETS UDBREDELSE I DET NORDLIGE JYLLAND

D.G.U. IIR. Nr. 35 .

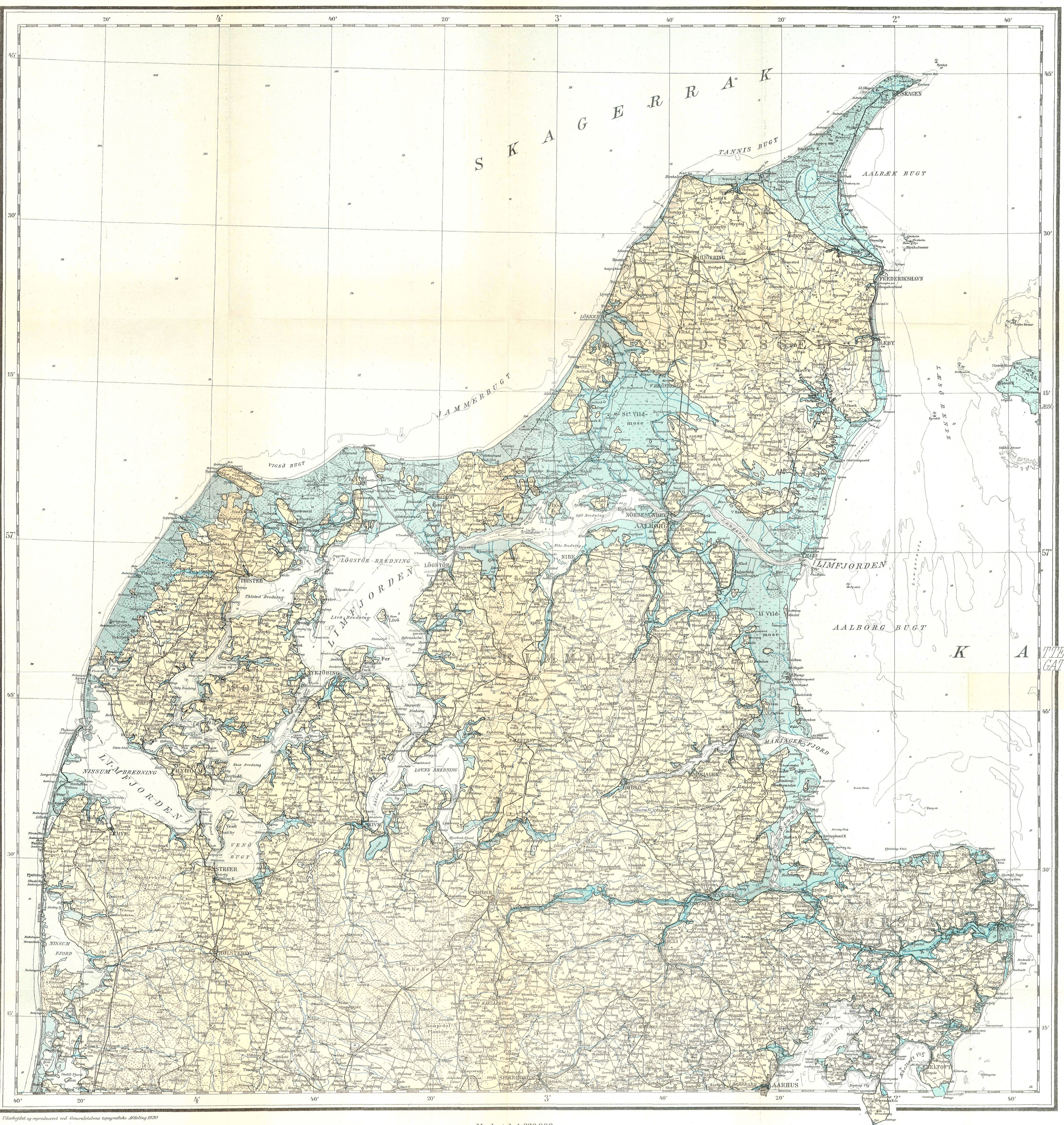

$\square=\square \quad \square \quad \square \quad \square \quad \square \quad \square \quad \square$ 